\title{
Congress of Neurological Surgeons Systematic Review and Evidence-based Guidelines Update on the Role of Targeted Therapies and Immunotherapies in the Management of Progressive Glioblastomaoncolo
}

\section{Evan Winograd}

University of Colorado Anschutz Medical Campus: University of Colorado - Anschutz Medical Campus Isabelle Germano

Mount Sinai School of Medicine: Icahn School of Medicine at Mount Sinai

\section{Patrick Wen}

Dana-Farber Cancer Institute

Jeffrey J. Olson

Emory University School of Medicine

David Ryan Ormond ( $\nabla$ david.ormond@ucdenver.edu )

University of Colorado Denver School of Medicine https://orcid.org/0000-0001-7027-2915

\section{Research Article}

Keywords: progressive glioblastoma, guidelines update, targeted therapy, immunotherapy

Posted Date: September 13th, 2021

DOl: https://doi.org/10.21203/rs.3.rs-842786/v1

License: (c) (1) This work is licensed under a Creative Commons Attribution 4.0 International License. Read Full License

Version of Record: A version of this preprint was published at Journal of Neuro-Oncology on October 25th, 2021. See the published version at https://doi.org/10.1007/s11060-021-03876-7. 


\section{Abstract}

The following questions and recommendations are pertinent to the following:

\section{Target Population}

These recommendations apply to adults with progressive GBM who have undergone standard primary treatment with surgery and/or chemoradiation.

\section{Question 1}

In adults with progressive glioblastoma is the use of bevacizumab as monotherapy superior to standard salvage cytotoxic chemotherapy as measured by progression free survival and overall survival?

\section{Recommendation}

Level III: Treatment with bevacizumab is suggested in the treatment of progressive GBM, as it provides improved disease control compared to historical controls as measured by best imaging response and progression free survival at 6 months, while not providing evidence for improvement in overall survival.

\section{Question 2}

In adults with progressive glioblastoma is the use of bevacizumab as combination therapy with cytotoxic agents superior to standard salvage cytotoxic chemotherapy as measured by progression free survival and overall survival?

\section{Recommendation}

Level III: There is insufficient evidence to show benefit or harm of bevacizumab in combination with cytotoxic therapies in progressive glioblastoma due to a lack of evidence supporting a clearly defined benefit without significant toxicity.

\section{Question 3}

In adults with progressive glioblastoma is the use of bevacizumab as a combination

therapy with targeted agents superior to standard salvage cytotoxic chemotherapy as measured by progression free survival and overall survival?

\section{Recommendation}

There is insufficient evidence to support a recommendation regarding this question.

\section{Question 4}


In adults with progressive glioblastoma is the use of targeted agents as monotherapy superior to standard salvage cytotoxic chemotherapy as measured by progression free survival and overall survival?

\section{Recommendation}

There is insufficient evidence to support a recommendation regarding this question.

\section{Question 5}

In adults with progressive glioblastoma is the use of targeted agents in combination with cytotoxic therapies superior to standard salvage cytotoxic chemotherapy as measured by progression free survival and overall survival?

\section{Recommendation}

There is insufficient evidence to support a recommendation regarding this question.

\section{Question 6}

In adults with progressive glioblastoma is the use of immunotherapy monotherapy superior to standard salvage cytotoxic chemotherapy as measured by progression free survival and overall survival?

\section{Recommendation}

There is insufficient evidence to support a recommendation regarding this question.

\section{Question 7}

In adults with progressive glioblastoma is the use of immunotherapy in combination with targeted agents superior to standard salvage cytotoxic chemotherapy as measured by progression free survival and overall survival?

\section{Recommendation}

There is insufficient evidence to support a recommendation regarding this question.

\section{Question 8}

In adults with progressive glioblastoma is the use of immunotherapy in combination with bevacizumab superior to standard salvage cytotoxic chemotherapy as measured by progression free survival and overall survival?

\section{Recommendation}

There is insufficient evidence to support a recommendation regarding this question. 


\section{Introduction}

In 2014, guidelines for the management of progressive glioblastoma and the role of targeted therapies were published by the AANS and CNS.[1] We now present the updated set of data and studies regarding targeted therapies as well as immunotherapy with and without targeted therapies. Despite maximal therapy, the median overall survival for a patient with newly diagnosed glioblastoma remains 14.6 months.[2] Recurrence typically occurs by one year and the median overall survival at recurrence ranges from 24 to 44 weeks.[3-5] Despite significant effort, the prognosis after recurrence in glioblastoma remains dismal. While cytotoxic therapies have long been used to treat malignancy, more recent attempts utilizing therapies targeting tumor progression and growth pathways, anti-angiogenic agents designed to target neovascular proliferation pathways, and immunotherapies aimed at utilizing a patient's immune system to attack tumor cells have been studied. We present a systematic review and evidence-based practice guideline to help practicing physicians to determine the role of these treatments in progressive glioblastoma.

\section{Rationale}

Tumor stabilization and radiographic response are the current goals in designing treatment of progressive glioblastoma. There are several strategies for treatment with targeted therapies, especially with the large amount of information being uncovered regarding the molecular characteristics of glioblastoma and the differing aberrations that occur in subgroups of the tumor. Exploration of immunotherapy has been a growing subject of study as well, with a goal of utilizing the patient's own immune response to attack the tumor.

\section{Objectives}

The objectives of this guideline are to assess the therapeutic value of targeted therapies and immunotherapies in patient with progressive glioblastoma based on radiographic response and in terms of survival outcomes.

\section{Methods}

\section{Writing Group and Question Establishment:}

The evidence-based clinical practice guideline taskforce members and the Joint Tumor Section of the American Association of Neurological Surgeons (AANS) and the Congress of Neurological Surgeons (CNS) have prioritized updating the guidelines for management of progressive glioblastoma with targeted therapies and immunotherapy. A series of authors for the development of guidelines related to the role of targeted therapy and immunotherapy in progressive glioblastoma were identified and screened for conflicts of interest. This group in turn agreed on a set of questions addressing the topic at hand and conducted a systematic review of the literature relevant to management of progressive glioblastoma with the aforementioned therapeutic strategies, both alone and in combination. Additional details of the 
systematic review are provided below and within the introduction and methodology chapter of the guideline.

\section{Literature Search}

The task force collaborated with a medical librarian and searched for articles published on targeted therapies for progressive glioblastoma between July 1, 2012 and March 31, 2019, and on immunotherapy for progressive glioblastoma between January 1, 1990 to March 31, 2019 (to complete the same search dates as had previously been performed in the original guideline document) in three electronic databases: Pubmed, EMBASE and Cochrane. Strategies for searching electronic databases were constructed by the evidence-based clinical practice guideline taskforce members and the medical librarian using standard strategies to identify relevant studies.[6-13]

\section{Search Strategy}

- Targeted: July 1, 2012 through March 31, 2019

(progress* OR recurren* OR relaps*) AND (glioma OR glioblastoma) AND (targeted therap* OR immunotherapy OR molecular agent* OR surgical technique* OR surgery OR radiotherap* OR alternative particles OR radiosensitizer* OR convection enhanced) AND (quality of life OR survival OR mortality)

- Immunotherapy: January 1, 1990 to March 31, 2019

(progress* OR recurren* OR relaps*) AND (glioma OR glioblastoma) AND (vaccin* OR peptide vaccin* OR heat shock protein vaccin* OR immune checkpoint inhibitor* OR dendritic cell vaccin* $O R$ adoptive T Cell») AND (quality of life OR surival OR mortality)

The authors supplemented the searches of electronic databases with manual screening of the bibliographies of all retrieved publications. The authors also searched the bibliographies of recent systematic reviews and other review articles for potentially relevant citations. All articles identified were subject to the study selection criteria listed below. As noted above, the guideline committee also examined lists of included and excluded studies for errors and omissions. The authors went to great lengths to obtain a complete set of relevant articles. Having a complete set ensured that this guideline was not based on a biased subset of articles.

\section{Study selection and Eligibility Criteria}

A total of 4417 articles were identified including 3513 for targeted therapies and 904 for immunotherapy (Figs. 1 and 2). Based on a Pubmed search, a total of 2727 articles in targeted therapy and 627 articles in immunotherapy related to progressive glioblastoma were reviewed by the team with specific inclusion and exclusion criteria outlined below. A search of Embase yielded 748 additional articles relating to targeted therapy and 253 in immunotherapy. Cochrane yielded an additional 38 articles for targeted therapy and 24 for immunotherapy. The same methodology of review was conducted for the Embase and 
Cochrane data. Independent reviewers evaluated and abstracted full-text data for each article and the two sets of data were compared for agreement by a third party. Inconsistencies were re-reviewed and disagreements were resolved by consensus. Citations were included that prospectively or retrospectively reviewed the treatment effect and outcomes of targeted therapies and immunotherapies, as monotherapy or combination therapies, on progressive glioblastoma patients. To be included in the guideline, a publication had to meet the following inclusion criteria:

- Investigated patients had progressive/progressive glioblastoma

- Patients $\geq 18$ years of age

- Humans, only

- Published between:

Targeted: July 1, 2012 through March 31, 2019

Immunotherapy: January 1, 1990 to March 31, 2019

- Quantitatively presented results

- Was not an in vitro study

- Was published in English

- Studies may include mixed pathology; however, the data pertaining to progressive glioblastoma was extractable from the paper

- Had $\geq 5$ patients or patient samples

The authors did not include systematic reviews, guidelines, or meta-analyses conducted by others. These documents are developed using different inclusion criteria than those specified in this guideline. Therefore, they may include studies that do not meet the inclusion criteria specified above. These documents were recalled if their abstract suggested that they might address one of the recommendations, and their bibliographies were searched for additional studies.

\section{Data Collection Process}

The abstracts that met the selection criteria mentioned above were retrieved in full-text form. Each article's adherence to the selection criteria was confirmed. To determine how the data could be classified, the information in the full-text articles were then evaluated to determine whether they were providing results of therapy or were more centered on diagnostic or prognostic information. Agreement on these assessments and on the salient points regarding the type of study design and objectives, and the conclusions and data classification was then reached by exchanging drafts and comments by e-mail. The information was then used for construction of the evidence tables. A summary of the search process and results are provided in the PRISMA diagrams (Figs. 1 and 2).

\section{Assessment for Risk of Bias}

Our search generated 4417 abstracts. These were screened, and the articles that addressed our predefined questions underwent full independent review by the authors. Reviewers were critical in their 
assessment to account for selection bias, survivorship bias, etc., by evaluating studies specifically in regard to trial design including factors such as: adequacy of control group, randomization of treatment, blinding, prospective character, size of study population, etc. Other factors that could account for survivorship bias or selection bias, as well as appropriate or inappropriate use of statistics of the reported data was also critically assessed.

\section{Classification of Evidence and Guideline Recommendation and Formulation}

The concept of linking evidence to recommendations has been further formalized by the American Medical Association (AMA) and many specialty societies, including the American Association of Neurological Surgeons (AANS), the Congress of Neurological Surgeons (CNS), and the American Academy of Neurology (AAN). This formalization involves the designation of specific relationships between the strength of evidence and the strength of recommendations to avoid ambiguity. In the paradigm for therapeutic maneuvers, evidence is classified into that which is derived from the strongest clinical studies (eg, well-designed, randomized controlled trials), or class I evidence. Class I evidence is used to support recommendations of the strongest type, defined as level 1 recommendations, indicating a high degree of clinical certainty. Nonrandomized cohort studies, randomized controlled trials with design flaws, and case-control studies (comparative studies with less strength) are designated as class II evidence. These are used to support recommendations defined as level 2 reflecting a moderate degree of clinical certainty. Other sources of information, including observational studies such as case series and expert opinion, as well as randomized controlled trials with flaws so serious that the conclusions of the study are truly in doubt are considered class III evidence and support level 3 recommendations, reflecting unclear clinical certainty. A summary of these categories of evidence can be viewed at https://www.cns.org/guidelines/guideline-development-methodology.

\section{Results}

\section{Role of targeted therapies in progressive glioblastoma}

\section{All questions and recommendations in this section apply to the following target population}

Adults with progressive GBM who have undergone standard primary treatment with surgery and/or chemoradiation. For each of the provided evidence tables, data extraction included study design, total number of patients, study parameters including treatment regimen, results including metrics of survival and progression free survival, complications including toxicity data, and author conclusions.

Question 1: In adults with progressive glioblastoma is the use of bevacizumab as monotherapy superior to standard salvage cytotoxic chemotherapy as measured by progression free survival and overall survival?

\section{Summary of Prior Recommendations}


In the previously published guidelines on the role of targeted therapies in the management of progressive glioblastoma in adults, it was recommended that bevacizumab be utilized to provide improved disease control in comparison to historical controls as measured by best imaging response and progression free survival at 6 months.[1] This was a Level III recommendation based on the available data. The previous data included both prospective trials and retrospective reviews, all of which were Class III evidence.[1]

\section{Recommendation: Level III}

Treatment with bevacizumab is suggested in the treatment of progressive GBM, as it provides improved disease control compared to historical controls as measured by best imaging response and progression free survival at 6 months, while not providing evidence for improvement in overall survival.

\section{Study selection and characteristics for the updated search}

The initial search strategy included 3513 candidate articles. A total of 65 articles remained for full text review. From these, 7 articles were included in the final review for question 1 and are included in Table 1 below.[14-20] 
Table 1

Bevacizumab monotherapy in progressive GBM

Author Description of study:

(year):

Balana et al (2017)

Study Description:
Retrospective review of Prolonged Survival in glioblastoma patients rechallenged with Bevacizumab after a previous response to Bevacizumab

Patient Population:

12 newly diagnosed (BEV-F), 16 patients with progressive glioblastoma (BEV-S) retreated with Bevacizumab at varying recurrences.

Treatment Regimen:

Treatment doses reportedly conformed to standard treatment regimens in patients with a prior response before progression of disease.
Data Conclusions:

Class:

III

Results:

Median OS:

BEV-F - 26.7m

BEV-S - 52.1m

Median PFS:

BEV-F:

BEV-1-7.9m, BEV-29.1m, BEV-3-5.6m

BEV-S:

BEV-1-23.3m

months. BEV-2-7.3m

Median Post

progression survival:

BEV-F - 26.7m

(designated as

survival after first

occurrence of

progression)

BEV-S - 39.6m

RR: of rechallenges 3.4\% CR, 55.2\% PR, $31.0 \%$ SD, $10.4 \%$ PD

Clinical response $89.6 \%$

Toxicity:

Author's Conclusions:

Patients who have a first objective response to bevacizumab and stop bevacizumab before progression can attain a second

Abbreviations: $\mathrm{BEV}=$ bevacizumab, $\mathrm{OS}=$ overall survival, $\mathrm{PFS}=$ progression free survival, $\mathrm{RR}=$ response rate, $\mathrm{PD}=$ progressive disease, $\mathrm{SD}=$ stable disease, $\mathrm{CR}=$ complete response, $\mathrm{PR}=$ partial response, $\mathrm{AE}=$ adverse event, $\mathrm{TMZ}$ = temozolomide, $\mathrm{GBM}=$ glioblastoma, $\mathrm{RT}$ = radiation therapy, $\mathrm{HTN}$ = hypertension, $\mathrm{CHF}$ = congestive heart failure, $\mathrm{VTE}=$ venous thromboembolism 


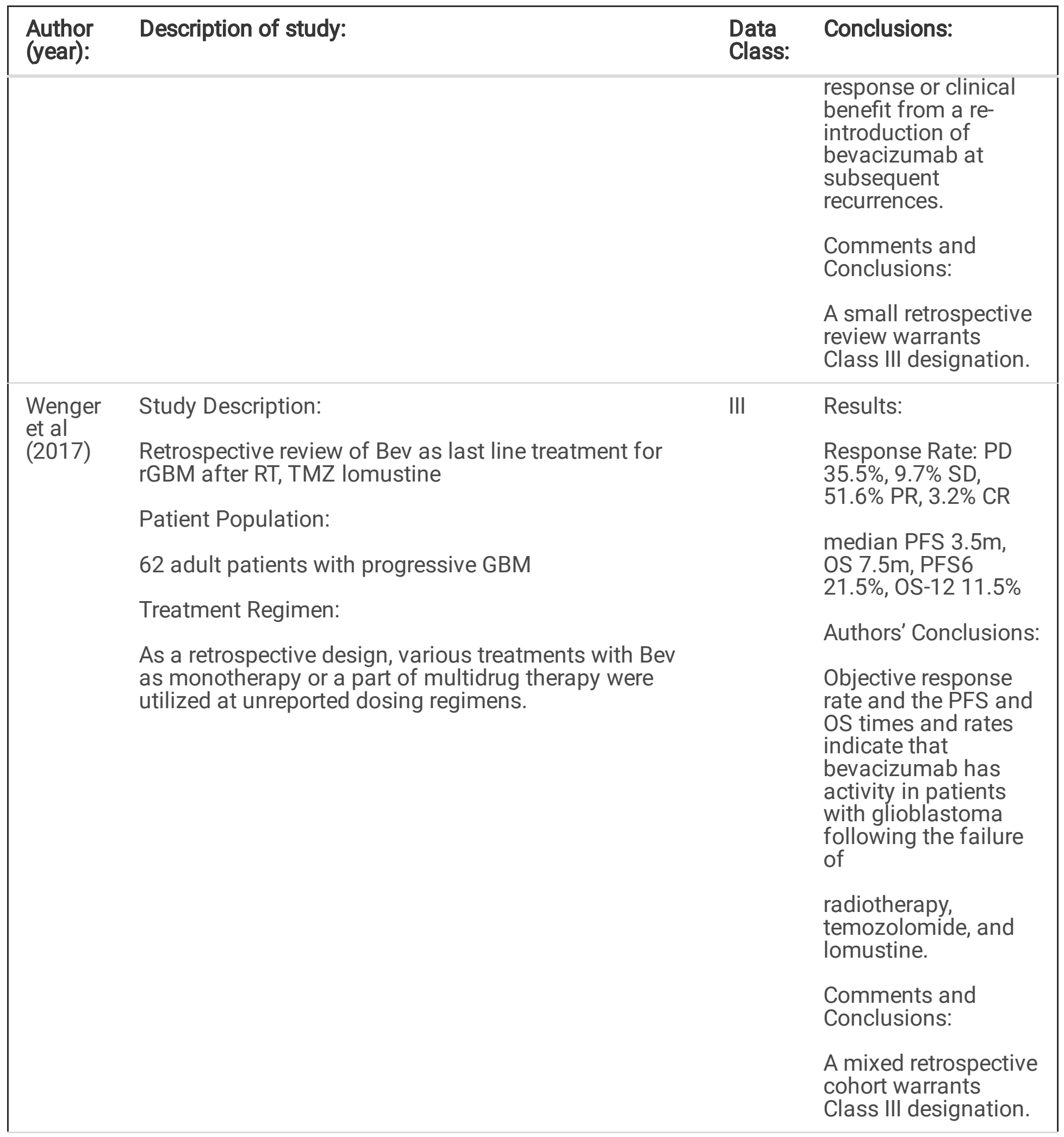

Abbreviations: $\mathrm{BEV}=$ bevacizumab, $\mathrm{OS}=$ overall survival, $\mathrm{PFS}=$ progression free survival, $\mathrm{RR}=$ response rate, $\mathrm{PD}=$ progressive disease, $\mathrm{SD}=$ stable disease, $\mathrm{CR}=$ complete response, $\mathrm{PR}=$ partial response, $\mathrm{AE}$ = adverse event, $\mathrm{TMZ}$ = temozolomide, $\mathrm{GBM}=$ glioblastoma, $\mathrm{RT}$ = radiation therapy, $\mathrm{HTN}$ = hypertension, $\mathrm{CHF}$ = congestive heart failure, $\mathrm{VTE}$ = venous thromboembolism 


\begin{tabular}{lll}
\hline $\begin{array}{l}\text { Author } \\
\text { (year): }\end{array}$ & Description of study: & Data \\
Class: & Conclusions:
\end{tabular}

Flieger Study Description:

et al

(2014) Retrospective review of Avastin and reirradiation in progressive GBM patients.

III

Results:

Patient Population:

71 adult patients with progressive high-grade glioma, 43 with Grade IV received BEV + reirradiation, 9 reirradiation only

Treatment Regimen:

Patients received a total

dose of $36 \mathrm{~Gy}$ in 18 fractions (2 Gy single doses) employing 3D conformal radiotherapy or IMRT if adjacent critical structures were present. Patients treated with bevacizumab received $10 \mathrm{mg} / \mathrm{kg}$ at days 1 and 15 during radiotherapy. If applied in patients who had no previous progression after TMZ pre-treatment a dosage of $75 \mathrm{mg} / \mathrm{m} 2$ daily was chosen.

median PFS: $5.1 \mathrm{~m}$, vs $3.4 \mathrm{~m}$ without Bev

Median PFS: $9.3 \mathrm{~m}$ vs $6.1 \mathrm{~m}$ without Bev

Toxicity:

one death (grade 5)

with known

diverticulosis, suffered GI

perforation. 2 grade 4 - thrombocytopenia and wound healing, 1 grade 3 - DVT.

Authors' Conclusions:

In conclusion, the results of the randomized controlled trials on the use of bevacizumab concomitantly to irradiation are expected-treatment will probably become more diverse; especially in those patients who were treated with a temozolomide-based radiochemotherapy.

Comments and Conclusions:

A retrospective study warrants Class III designation.

Abbreviations: $\mathrm{BEV}=$ bevacizumab, $\mathrm{OS}=$ overall survival, $\mathrm{PFS}=$ progression free survival, $\mathrm{RR}=$ response rate, $\mathrm{PD}=$ progressive disease, $\mathrm{SD}=$ stable disease, $\mathrm{CR}=$ complete response, $\mathrm{PR}=$ partial response, $\mathrm{AE}$ = adverse event, $\mathrm{TMZ}$ = temozolomide, $\mathrm{GBM}=$ glioblastoma, $\mathrm{RT}$ = radiation therapy, $\mathrm{HTN}$ = hypertension, $\mathrm{CHF}=$ congestive heart failure, $\mathrm{VTE}$ = venous thromboembolism 


\begin{tabular}{|c|c|c|c|}
\hline $\begin{array}{l}\text { Author } \\
\text { (year): }\end{array}$ & Description of study: & $\begin{array}{l}\text { Data } \\
\text { Class: }\end{array}$ & Conclusions: \\
\hline $\begin{array}{l}\text { Piccioni } \\
\text { et al } \\
(2014)\end{array}$ & $\begin{array}{l}\text { Study Description: } \\
\text { retrospective study of participants treated with BEV at } \\
\text { several institutions to } \\
\text { determine factors impacting survival with progressive } \\
\text { GBM } \\
\text { Patient Population: } \\
388 \text { adult participants who received BEV at recurrence, } \\
121 \text { received BEV monotherapy, and } 267 \text { were treated } \\
\text { with BEV plus concurrent chemotherapy } \\
(B V+) \text {. }\end{array}$ & III & $\begin{array}{l}\text { Results: } \\
\text { median PFS with BEV } \\
-1 \text { st recurrence } \\
4.1 \mathrm{~m}, 2 \mathrm{nd} 4.2 \mathrm{~m}, 3 \mathrm{rd} \\
3.4 \mathrm{~m} \\
\text { median OS with BEV: } \\
1 \text { st } 8.4 \mathrm{~m}, 2 \mathrm{nd} 9.3 \mathrm{~m}, \\
3 \mathrm{rd} 6.4 \mathrm{~m} \\
\text { PFS for BEV alone } \\
3.6 \mathrm{~m}, \mathrm{BV}+\text { other } \\
\text { treatment } 4.3 \mathrm{~m} \\
\text { Toxicities: } \\
\text { NR } \\
\text { Authors' Conclusions: } \\
\text { BEV efficacy is not } \\
\text { diminished at later } \\
\text { recurrences and } \\
\text { suggests that } \\
\text { delayed use of BEV } \\
\text { may be preferable } \\
\text { Comments and } \\
\text { Conclusions: } \\
\text { A retrospective study } \\
\text { warrants Class III } \\
\text { designation. }\end{array}$ \\
\hline
\end{tabular}

Abbreviations: $\mathrm{BEV}=$ bevacizumab, $\mathrm{OS}=$ overall survival, $\mathrm{PFS}=$ progression free survival, $\mathrm{RR}=$ response rate, $\mathrm{PD}=$ progressive disease, $\mathrm{SD}=$ stable disease, $\mathrm{CR}=$ complete response, $\mathrm{PR}=$ partial response, $\mathrm{AE}=$ adverse event, $\mathrm{TMZ}$ = temozolomide, $\mathrm{GBM}=$ glioblastoma, $\mathrm{RT}$ = radiation therapy, $\mathrm{HTN}$ = hypertension, $\mathrm{CHF}=$ congestive heart failure, $\mathrm{VTE}$ = venous thromboembolism 


\begin{tabular}{llll}
\hline $\begin{array}{l}\text { Author } \\
\text { (year): }\end{array}$ & Description of study: & Data & Conclusions: \\
& & Class: &
\end{tabular}

Cai et Study Description:

al

(2013)
Bevacizumab rescue therapy in patients with progressive malignant glioma: a retrospective analysis.

Patient Population:

20 adult patients enrolled with progressive GBM, 12 received Bev rescue, 8 received placebo.

Treatment Regimen:

Twenty-two patients with second recurrence or poor response to dense-dose chemotherapy received salvage bevacizumab therapy at a dose of $10 \mathrm{mg} / \mathrm{kg}$. The remaining 29 patients received best care support, with or without other chemotherapeutic regimens including temozolomide plus cisplatin, nimustine and teniposide, or nimustine, cisplatin and VP-16, and nimustine monotherapy. Bevacizumab was terminated upon disease progression or treatment-related toxicity (grade 4 or above).
III

\section{Results:}

OS: with BEV - 8.9m, placebo $5.6 \mathrm{~m}$

$6 \mathrm{~m}$ Survival: $83 \%$ with BEV, $47 \%$ placebo.

PFS: $3 \mathrm{~m}$ for BEV, $1 \mathrm{~m}$ for Placebo

Toxicity:

No grade 3-4 adverse events reported.

Authors' Conclusions:

Salvage therapy with $\mathrm{BEV}$ is

effective and safe for patients with grade IV glioma, conferring a survival benefit without incurring additional side effects.

Comments and Conclusions:

A study with few patients and retrospective in nature warrants Class III designation.

Kaloshi Study Description:

et al (2013)

Retrospective study of bevacizumab $5 \mathrm{mg} / \mathrm{kg}$ every 3 weeks for adult patients with progressive GBM

Patient Population:

14 patients with progressive GBM were included (most with surgical debulking $n=11$ ).
Results:

Median OS: 6.4 mos

Response to treatment: The median number of cycles was 4 . Five patients had PR, 7 SD, 2 PD. When present, clinical

Abbreviations: $\mathrm{BEV}=$ bevacizumab, $\mathrm{OS}=$ overall survival, $\mathrm{PFS}=$ progression free survival, $\mathrm{RR}=$ response rate, $\mathrm{PD}=$ progressive disease, $\mathrm{SD}=$ stable disease, $C R=$ complete response, $\mathrm{PR}=$ partial response, $\mathrm{AE}=$ adverse event, $\mathrm{TMZ}$ = temozolomide, $\mathrm{GBM}=$ glioblastoma, $\mathrm{RT}$ = radiation therapy, $\mathrm{HTN}$ = hypertension, $\mathrm{CHF}=$ congestive heart failure, $\mathrm{VTE}=$ venous thromboembolism 


\begin{tabular}{|c|c|c|c|}
\hline $\begin{array}{l}\text { Author } \\
\text { (year): }\end{array}$ & Description of study: & $\begin{array}{l}\text { Data } \\
\text { Class: }\end{array}$ & Conclusions: \\
\hline & $\begin{array}{l}\text { Treatment Regimen: Bevacizumab } 5 \mathrm{mg} / \mathrm{kg} \text { alone every } \\
3 \text { weeks until progression, administered IV over } 90 \mathrm{~min} \\
\text { first cycle and over } 60 \text { min for following cycle with no } \\
\text { dose escalation permitted. Treatment continued until } \\
\text { disease progression, toxicity or withdrawal of consent. }\end{array}$ & & $\begin{array}{l}\text { improvement } \\
\text { followed second } \\
\text { week of the cycle. } \\
\text { Dexamethasone dose } \\
\text { was decreased in } \\
\text { patients with } \\
\text { radiological or } \\
\text { clinical improvement. }\end{array}$ \\
\hline & & & Toxicity: \\
\hline & & & $\begin{array}{l}\text { Fatigue was the most } \\
\text { common adverse } \\
\text { event (4 patients, } \\
\text { grade } 1 \text { and } 2) \text {. There } \\
\text { was no grade } 3 \text { or } 4 \\
\text { hematological or } \\
\text { clinical toxicities, no } \\
\text { symptomatic } \\
\text { intracerebral bleeding } \\
\text { and no treatment- } \\
\text { related death. }\end{array}$ \\
\hline & & & Authors' Conclusions: \\
\hline & & & $\begin{array}{l}\text { In view of tolerance, } \\
\text { patient comfort and } \\
\text { economic issues, the } \\
\text { finding that BEV at } 5 \\
\text { mg/kg every } 3 \text { weeks } \\
\text { has significant } \\
\text { activity in progressive } \\
\text { GBM warrants further } \\
\text { investigation. }\end{array}$ \\
\hline & & & $\begin{array}{l}\text { Comments and } \\
\text { Conclusions: }\end{array}$ \\
\hline & & & $\begin{array}{l}\text { A retrospective study } \\
\text { design warrants } \\
\text { Class III designation. }\end{array}$ \\
\hline
\end{tabular}

Abbreviations: $\mathrm{BEV}=$ bevacizumab, $\mathrm{OS}=$ overall survival, $\mathrm{PFS}=$ progression free survival, $\mathrm{RR}=$ response rate, $\mathrm{PD}=$ progressive disease, $\mathrm{SD}=$ stable disease, $\mathrm{CR}=$ complete response, $\mathrm{PR}=$ partial response, $\mathrm{AE}=$ adverse event, $\mathrm{TMZ}$ = temozolomide, $\mathrm{GBM}=$ glioblastoma, $\mathrm{RT}$ = radiation therapy, $\mathrm{HTN}$ = hypertension, $\mathrm{CHF}=$ congestive heart failure, $\mathrm{VTE}$ = venous thromboembolism 


\begin{tabular}{|c|c|c|c|}
\hline $\begin{array}{l}\text { Author } \\
\text { (year): }\end{array}$ & Description of study: & $\begin{array}{l}\text { Data } \\
\text { Class: }\end{array}$ & Conclusions: \\
\hline $\begin{array}{l}\text { Nagane } \\
\text { et al } \\
\text { (2012) }\end{array}$ & $\begin{array}{l}\text { Study Description: } \\
\text { A single-arm open-label Phase II study using single- } \\
\text { agent bevacizumab in progressive malignant glioma in } \\
\text { Japanese patients } \\
\text { Patient Population: } \\
\text { Adult Japanese patients with progressive GBM }(n=29) \\
\text { or AA }(n=2) \text {. } \\
\text { Treatment Regimen: bevacizumab IV } 10 \mathrm{mg} / \mathrm{kg} \text { every } 2 \\
\text { weeks. }\end{array}$ & III & $\begin{array}{l}\text { Results: } \\
\text { Median OS: } 10.5 \text { mos } \\
\text { Response to } \\
\text { treatment: Among the } \\
\text { GBM subset, } 21 \\
\text { patients experienced } \\
\text { tumor shrinkage } \\
\text { during the treatment } \\
\text { period. } 8 \text { PR. PFS6 } \\
33.9 \% \text {. } \\
\text { Toxicity: } \\
\text { All } 31 \text { patients had } \\
\text { AE, serious AE in } 11 \\
\text { patients (two } \\
\text { convulsion, } 1 \text { Grade } 1 \\
\text { cerebral hemorrhage, } \\
3 \text { patients with Grade } \\
3 \text { HTN, } 1 \text { patient died } \\
\text { of cerebral edema, } 1 \\
\text { CHF, } 1 \text { VTE. } \\
\text { Authors' Conclusions: } \\
\text { The results of this } \\
\text { study show that } \\
\text { single agent BEV } \\
\text { could provide } \\
\text { significant clinical } \\
\text { benefit for Japanese } \\
\text { patients with } \\
\text { progressive GBM. } \\
\text { Comments and } \\
\text { Conclusions: } \\
\text { A single arm study } \\
\text { without control } \\
\text { warrants Class III } \\
\text { designation. }\end{array}$ \\
\hline $\begin{array}{l}\text { Abbrevia } \\
\text { respons } \\
\text { respons } \\
=\text { hypert }\end{array}$ & $\begin{array}{l}\text { ns: } \mathrm{BEV}=\text { bevacizumab, } \mathrm{OS}=\text { overall survival, } \mathrm{PFS}=\mathrm{prc} \\
\text { te, } \mathrm{PD}=\text { progressive disease, } \mathrm{SD}=\text { stable disease, } \mathrm{CR}= \\
\mathrm{E}=\text { adverse event, } \mathrm{TMZ}=\text { temozolomide, } \mathrm{GBM}=\text { gliobla } \\
\text { ion, } \mathrm{CHF}=\text { congestive heart failure, } \mathrm{VTE}=\text { venous throm }\end{array}$ & $\begin{array}{l}\text { Sion } \\
\text { lete } \\
\text { a, RT } \\
\text { nboli }\end{array}$ & $\begin{array}{l}\text { survival, } \mathrm{RR}= \\
\text { onse, } \mathrm{PR}=\text { partial } \\
\text { adiation therapy, HTN }\end{array}$ \\
\hline
\end{tabular}

Only two of the studies were prospective trials. One was performed in Japan, by Nagane et al.[17] They evaluated 29 progressive glioblastoma patients given a regimen of standard dose BEV and found mOS was 10.5 months. They had a significant number of radiographic responses with 21 patients experiencing reduction in tumor size during treatment and a PFS 6 of 33.9\%. They concluded that, similar 
to other studies performed outside Japan, their native patient population with progressive glioblastoma experienced a significant survival benefit.[21-23] Cai et al reviewed 20 patients in a double arm comparative study comparing BEV to a placebo treatment.[14] Of the patients with glioblastoma $(n=20)$, mOS was 8.9 months with BEV and 5.6 months with placebo, and a 6 month survival of $83 \%$ versus $47 \%$ respectively. The authors concluded that bevacizumab conferred a survival benefit.

Six of the studies were retrospective reviews.[14-16; 18-20] Kaloshi et al evaluated the survival effect on 11 patients receiving low-dose BEV, finding mOS of 6.4 months and only five patients with a partial response, at best. The coupling of low toxicity and some efficacy lead them to conclude BEV was effective in these patients.[16] Wenger et al reviewed 62 patients with multiple treatment regimens, however all had undergone and failed initial standard therapy with RT, TMZ, and lomustine.[19] Ultimately, their RR showed 51.6\% PR and 3.2\% with CR, a median PFS of 3.5 months and m0S 7.5 months. They felt this data showed BEV remained effective after failed standard treatment and lomustine. Meanwhile, Piccioni et al. reviewed data from multiple institutions including 388 patients receiving $B E V$ at recurrence, however in varying methodologies including combination therapy.[18] Progression free survival for BEV alone was 3.6 months and 4.6 months in combination therapy. Their data showed that BEV retained its efficacy throughout multiple recurrences, with data including the varying recurrences at which BEV was started, however the data was mixed with multiple therapy modalities. Balana et al also studied patients rechallenged with BEV after prior treatment response to the drug, and noted a survival benefit, possibly in the subset of patients that displayed sensitivity and response to initial treatment with $B E V$, if $B E V$ was halted for reasons other than progression.[20] Flieger et al reviewed their data on patients receiving repeat RT therapy along with BEV.[15] PFS was 5.1 months with and 3.4 months without bevacizumab. Median OS was 9.3 months in combination therapy, 6.1 months with RT alone and the authors concluded that BEV concomitantly given with reirradiation was feasible and effective based on comparison to historical data.

\section{Synthesis:}

Historically, PFS-6 ranged from 29-50.3\% based on three studies evaluating BEV monotherapy compared with combination therapy with irinotecan, with Friedman et al showing in a prospective, randomized Phase II trial a mOS of 9.2 months with BEV alone.[22-24] Two prospective trials with BEV above showed a PFS- 6 of $33.9 \%$ and $83 \%$, compatible with the historical data.[17] In one, the data was a single arm study without a control group, and the other a small case series where the controls fared better than controls in other studies. For this reason, these prospective studies remained Class III evidence. The remainder of the data was retrospective, all of which were downgraded to Class III evidence, as well. [14$16 ; 18 ; 19]$ While these studies met the inclusion criteria, they did not provide enough high level evidence to change or upgrade the recommendation from the previous guideline.

Question 2: In adults with progressive glioblastoma is the use of bevacizumab as combination therapy with cytotoxic agents superior to standard salvage cytotoxic chemotherapy as measured by progression free survival and overall survival? 
Prior Recommendation: In the previously published guidelines on the role of targeted therapies in the management of progressive glioblastoma in adults, bevacizumab combined with cytotoxic agents was reviewed and no specific recommendations were made based on a lack of strong evidence supporting a clearly defined benefit without significant toxicity.[1]

\section{Recommendation Level: III}

There is insufficient evidence to show benefit or harm of bevacizumab in combination with cytotoxic therapies in progressive glioblastoma due to a lack of evidence supporting a clearly defined benefit without significant toxicity.

\section{Study selection and characteristics of the updated search:}

The initial search strategy included 3513 candidate articles. A total of 65 articles remained for full text review. From these, 21 articles were included in the final review for question 2 and are included in Table 2 below. [25-44] 
Table 2

The role of bevacizumab combined with cytotoxic therapy in progressive GBM.

\begin{tabular}{|c|c|c|c|}
\hline $\begin{array}{l}\text { Author } \\
\text { (year): }\end{array}$ & Description of study: & $\begin{array}{l}\text { Data } \\
\text { Class: }\end{array}$ & Conclusions: \\
\hline \multirow{11}{*}{$\begin{array}{l}\text { Brandes et } \\
\text { al (2019) }\end{array}$} & Study Description: & II & Results: \\
\hline & \multirow{2}{*}{$\begin{array}{l}\text { TAMIGA (NCT01860638) was a phase II, } \\
\text { randomized, double-blind, placebo- } \\
\text { controlled, multicenter trial in adult } \\
\text { patients with glioblastoma. }\end{array}$} & & $\begin{array}{l}\text { CCNU + BEV OS: } 6.4 \mathrm{~m}, \mathrm{PFS} 2- \\
2.3 \mathrm{~m}, \mathrm{PFS} 3-2.0\end{array}$ \\
\hline & & & $\begin{array}{l}\text { CCNU + BEV OS: } 6.4 \mathrm{~m}, \text { PFS2- } \\
2.3 \mathrm{~m}, \text { PFS3 }-2.0\end{array}$ \\
\hline & \multirow{2}{*}{$\begin{array}{l}\text { Patient Population: } \\
123 \text { patients were randomized at the time } \\
\text { of progressive disease (PD1) with } 61 \text { in } \\
\text { the CCNU + BEV group, } 62 \text { in the Placebo + } \\
\text { CCNU group. } 25 \text { patients in each group } \\
\text { received 3rd line treatment at PD2. }\end{array}$} & & $x^{\prime}$ \\
\hline & & & $\begin{array}{l}\text { In the CCNU + BEV and the } \\
\text { CCNU + placebo groups, } \\
\text { respectively, } 86 \% \text { and } 83 \% \\
\text { experienced at least one AE, } \\
19 \% \text { and } 15 \% \text { exnerienced at }\end{array}$ \\
\hline & \multirow{6}{*}{$\begin{array}{l}\text { Treatment Regimen: Randomization } \\
\text { occurred at PD1 (second line), and } \\
\text { patients received lomustine (CCNU) plus } \\
\text { BEV (CCNU + BEV) or CCNU plus placebo } \\
\text { (CCNU + placebo) until further disease } \\
\text { progression (PD2). At PD2 (third line), } \\
\text { patients continued BEV or placebo with } \\
\text { chemotherapy } \\
\text { (investigator's choice). }\end{array}$} & & $\begin{array}{l}\text { least one treatment related } \mathrm{AE} \\
\text { greater than grade } 3,21 \% \text { and } \\
15 \% \text { experienced an } \mathrm{AE} \text { leading } \\
\text { to study discontinuation. }\end{array}$ \\
\hline & & & Authors' Conclusions: \\
\hline & & & $\begin{array}{l}\text { There was no survival benefit } \\
\text { and no detriment }\end{array}$ \\
\hline & & & $\begin{array}{l}\text { observed with continuing BEV } \\
\text { through multiple lines in } \\
\text { patients with progressive } \\
\text { glioblastoma. }\end{array}$ \\
\hline & & & Comments and Conclusions: \\
\hline & & & $\begin{array}{l}\text { A double-blind, placebo- } \\
\text { controlled multicenter trial in a } \\
\text { moderate, but relatively small } \\
\text { cohort, warrants Class II } \\
\text { designation. }\end{array}$ \\
\hline
\end{tabular}

Abbreviations: $\mathrm{BEV}=$ bevacizumab, $\mathrm{OS}=$ overall survival, $\mathrm{PFS}=$ progression free survival, $\mathrm{RR}=$ response rate, $\mathrm{PD}=$ progressive disease, $\mathrm{SD}=$ stable disease, $\mathrm{CR}=$ complete response, $\mathrm{PR}=$ partial response, $\mathrm{AE}=$ adverse event, $\mathrm{TMZ}=$ temozolomide, $\mathrm{GBM}=$ glioblastoma, $\mathrm{RT}=$ radiation therapy, $\mathrm{HTN}$ $=$ hypertension, $\mathrm{CHF}=$ congestive heart failure, $\mathrm{VTE}=$ venous thromboembolism, $\mathrm{CCNU}=$ lomustine, $\mathrm{PD}=$ disease progression, IRI = irinotecan 


\begin{tabular}{|c|c|c|c|}
\hline $\begin{array}{l}\text { Author } \\
\text { (year): }\end{array}$ & Description of study: & $\begin{array}{l}\text { Data } \\
\text { Class: }\end{array}$ & Conclusions: \\
\hline \multirow{13}{*}{$\begin{array}{l}\text { Brenner et } \\
\text { al (2018) }\end{array}$} & Study Description: & III & Results: \\
\hline & \multirow{3}{*}{$\begin{array}{l}\text { Phase I Surgical Study giving } \\
\text { evofosfamide and Bevacizumab to } \\
\text { bevacizumab resistant progressive GBM } \\
\text { patients vs. Bev + Placebo }\end{array}$} & & OS: $4.41 \mathrm{~m}$ \\
\hline & & & Time to Progression: $2.2 \mathrm{~m}$ \\
\hline & & & Tumor Response: Complete \\
\hline & Patient Population: & & and partial response $-17.4 \%$. \\
\hline & \multirow{3}{*}{$\begin{array}{l}28 \text { patients randomized to cohorts of } \\
\text { Presurgical Evofosfamide + Bev vs Bev + } \\
\text { Placebo, vs no surgery and only dose } \\
\text { escalation evaluation of combination } \\
\text { therapy. } 2 \text { patients withdrew consent post } \\
\text { op, } 3 \text { patients did not recover sufficiently, } 9 \\
\text { total patients continued to combination } \\
\text { therapy after surgery. }\end{array}$} & & $\begin{array}{l}\text { partial, and stable disease) in } \\
60.9 \% \text {. }\end{array}$ \\
\hline & & & Toxicity: \\
\hline & & & $\begin{array}{l}\text { No grade } 4 \text { adverse events. } 3 \\
\text { grade } 3 \text { adverse events, } \\
\text { including oral mucositis, skin }\end{array}$ \\
\hline & \multirow{2}{*}{$\begin{array}{l}\text { Treatment Regimen: Twenty-eight patients } \\
\text { with Bev-refractory GBM were enrolled in a } \\
\text { dose escalation study receiving from }\end{array}$} & & 11 patients developed rash. \\
\hline & & & Authors' Conclusions: \\
\hline & \multirow[t]{3}{*}{$\begin{array}{l}240 \mathrm{mg} / \mathrm{m} 2 \text { (cohort } 1 \text { ) to } 670 \mathrm{mg} / \mathrm{m} 2 \\
\text { (cohort 4) of Evo every } 2 \text { weeks in } \\
\text { combination with Bev. Patients deemed } \\
\text { surgical candidates underwent a single } \\
\text { dose of Evo or placebo with pimonidazole } \\
\text { immediately prior to surgery for biomarker } \\
\text { evaluation, followed by dose escalation } \\
\text { upon recovery. }\end{array}$} & & $\begin{array}{l}\text { Evo plus Bev was well } \\
\text { tolerated in patients with Bev- } \\
\text { refractory GBM, with } \\
\text { preliminary evidence of activity } \\
\text { that merits further } \\
\text { investigation }\end{array}$ \\
\hline & & & Comments and Conclusions: \\
\hline & & & $\begin{array}{l}\text { A small randomized cohort } \\
\text { warrants Class III designation. }\end{array}$ \\
\hline
\end{tabular}

Abbreviations: $\mathrm{BEV}=$ bevacizumab, $\mathrm{OS}=$ overall survival, $\mathrm{PFS}=$ progression free survival, $\mathrm{RR}=$ response rate, $\mathrm{PD}=$ progressive disease, $\mathrm{SD}=$ stable disease, $\mathrm{CR}=$ complete response, $\mathrm{PR}=$ partial response, $\mathrm{AE}$ = adverse event, $\mathrm{TMZ}$ = temozolomide, $\mathrm{GBM}=$ glioblastoma, $\mathrm{RT}$ = radiation therapy, $\mathrm{HTN}$ $=$ hypertension, $\mathrm{CHF}=$ congestive heart failure, $\mathrm{VTE}=$ venous thromboembolism, $\mathrm{CCNU}=$ lomustine, $\mathrm{PD}=$ disease progression, IRI = irinotecan 


\begin{tabular}{|c|c|c|c|}
\hline $\begin{array}{l}\text { Author } \\
\text { (year): }\end{array}$ & Description of study: & $\begin{array}{l}\text { Data } \\
\text { Class: }\end{array}$ & Conclusions: \\
\hline \multirow{11}{*}{$\begin{array}{l}\text { Johansen } \\
\text { et al (2018) }\end{array}$} & Study Description: & \multirow[t]{11}{*}{ III } & Results: \\
\hline & BEV therapy in patients with progressive & & Median OS: NR \\
\hline & inhibitors (retrospective) & & \multirow{4}{*}{$\begin{array}{l}\text { Response to treatment: In } \\
\text { univariate analysis, use of } \\
\text { angiotensin system inhibitors } \\
\text { was associated with a trend } \\
\text { towards improved PFS (HR } \\
0.75 \text { ) and OS (HR: 0.80). } \\
\text { Calcium antagonists } \\
\text { significantly improved OS (HR } \\
=0.57 \text { ) }\end{array}$} \\
\hline & Patient Population: & & \\
\hline & $\begin{array}{l}\text { Adult patients in a national prescription } \\
\text { registry were combined with a clinical } \\
\text { database with progressive GBM patients } \\
\text { ( } n=243,26 \text { in both databases). }\end{array}$ & & \\
\hline & Treatment Regimen: & & \\
\hline & \multirow[t]{5}{*}{$\begin{array}{l}\text { BEV } 10 \mathrm{mg} / \mathrm{kg} \text { and irinotecan } 125 \\
\mathrm{mg} / \mathrm{m}^{\wedge} 2 \text { both every } 2 \text { weeks. }\end{array}$} & & NR \\
\hline & & & Authors' Conclusions: \\
\hline & & & $\begin{array}{l}\text { Overall the study supports a } \\
\text { potential beneficial effect of } \\
\text { antihypertensive treatment on } \\
\text { prognosis of BEV treated GBM } \\
\text { patients. }\end{array}$ \\
\hline & & & Comments and Conclusions: \\
\hline & & & $\begin{array}{l}\text { A retrospective study warrants } \\
\text { Class III designation. }\end{array}$ \\
\hline
\end{tabular}

Abbreviations: $\mathrm{BEV}=$ bevacizumab, $\mathrm{OS}=$ overall survival, $\mathrm{PFS}=$ progression free survival, $\mathrm{RR}=$ response rate, $\mathrm{PD}=$ progressive disease, $\mathrm{SD}=$ stable disease, $\mathrm{CR}=$ complete response, $\mathrm{PR}=$ partial response, $\mathrm{AE}=$ adverse event, $\mathrm{TMZ}=$ temozolomide, $\mathrm{GBM}=$ glioblastoma, $\mathrm{RT}$ = radiation therapy, $\mathrm{HTN}$ $=$ hypertension, $\mathrm{CHF}=$ congestive heart failure, $\mathrm{VTE}=$ venous thromboembolism, $\mathrm{CCNU}=$ lomustine, $\mathrm{PD}=$ disease progression, IRI = irinotecan 


\begin{tabular}{|c|c|c|c|}
\hline $\begin{array}{l}\text { Author } \\
\text { (year): }\end{array}$ & Description of study: & $\begin{array}{l}\text { Data } \\
\text { Class: }\end{array}$ & Conclusions: \\
\hline $\begin{array}{l}\text { Pasqualetti } \\
\text { et al (2018) }\end{array}$ & $\begin{array}{l}\text { Study Description: } \\
\text { BEV in progressive GBM after second-line } \\
\text { chemotherapy with fotemustine } \\
\text { (retrospective) } \\
\text { Patient Population: } \\
51 \text { patients with progressive GBM } \\
\text { Treatment Regimen: } \\
\text { Fotemustine previously given at varied } \\
\text { dosing paradigms. BEV } 10 \mathrm{mg} / \mathrm{kg} \text { every } 2 \\
\text { weeks in } 43 \text { patients, } 15 \mathrm{mg} / \mathrm{kg} \text { every } 3 \\
\text { weeks in } 5 \text { patients, and } 7.5 \mathrm{mg} / \mathrm{kg} \text { every } 2 \\
\text { weeks in } 3 \text { patients }\end{array}$ & III & $\begin{array}{l}\text { Results: } \\
\text { Median OS: } 6 \text { mos } \\
\text { Response to treatment: PFS6 } \\
\text { 18\%, PFS12 13\% } \\
\text { Toxicity: } \\
\text { Grade } 3 \text { toxicity in } 3 \text { patients } \\
\text { (5.8\%) including } 1 \text { Gl fistula. } 2 \\
\text { Grade } 4 \text { toxicities with } \\
\text { thromboembolic event and } \\
\text { massive PE. } \\
\text { Authors' Conclusions: } \\
\text { The failure of second-line } \\
\text { chemotherapy with cytotoxic } \\
\text { agents might not exclude the } \\
\text { administration of BEV as third- } \\
\text { line chemotherapy. } \\
\text { Comments and Conclusions: } \\
\text { A retrospective study warrants } \\
\text { Class Ill designation. }\end{array}$ \\
\hline
\end{tabular}

Abbreviations: $\mathrm{BEV}=$ bevacizumab, $\mathrm{OS}=$ overall survival, $\mathrm{PFS}=$ progression free survival, $\mathrm{RR}=$ response rate, $\mathrm{PD}=$ progressive disease, $\mathrm{SD}=$ stable disease, $\mathrm{CR}=$ complete response, $\mathrm{PR}=$ partial response, $\mathrm{AE}=$ adverse event, $\mathrm{TMZ}$ = temozolomide, $\mathrm{GBM}=$ glioblastoma, $\mathrm{RT}$ = radiation therapy, $\mathrm{HTN}$ $=$ hypertension, $\mathrm{CHF}=$ congestive heart failure, $\mathrm{VTE}=$ venous thromboembolism, $\mathrm{CCNU}=$ lomustine, $\mathrm{PD}=$ disease progression, $\mathrm{IRI}=$ irinotecan 


\begin{tabular}{|c|c|c|c|}
\hline $\begin{array}{l}\text { Author } \\
\text { (year): }\end{array}$ & Description of study: & $\begin{array}{l}\text { Data } \\
\text { Class: }\end{array}$ & Conclusions: \\
\hline \multirow{11}{*}{$\begin{array}{l}\text { Badruddoja } \\
\text { et al (2017) }\end{array}$} & Study Description: & \multirow[t]{11}{*}{ III } & Results: \\
\hline & $\begin{array}{l}\text { Phase } 2 \text { study of bi-weekly TMZ plus BEV } \\
\text { with progressive GBM }\end{array}$ & & Median OS: 51 weeks \\
\hline & \multirow{2}{*}{ Patient Population: } & & Response to treatment: PFS6 \\
\hline & & & $\begin{array}{l}\text { was } 52 \% \text { with median PFS } \\
22.7 \text { weeks. }\end{array}$ \\
\hline & 30 adult patients with progressive GBM & & \\
\hline & Treatment Regimen: & & 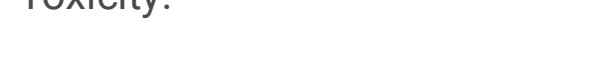 \\
\hline & $\begin{array}{l}\text { Bevacizumab }(10 \mathrm{mg} / \mathrm{kg} \text { i.v. }) \text { was given on } \\
\text { days } 1 \text { and } 15 \text { of a } 28 \text {-day cycle combined } \\
\text { with temozolomide }\left(100 \mathrm{mg} / \mathrm{m}^{2}\right) \text { on days } \\
1-5 \text { and } 15-19 \text { on a } 28 \text {-day cycle. }\end{array}$ & & $\begin{array}{l}\text { Most common side effects } \\
\text { were fatigue, urinary tract } \\
\text { infection, nausea, insomnia, } \\
\text { leukopenia and HTN. Most } \\
\text { serious were status epilepticus, } \\
\text { PE, nocardia pneumonia (one } \\
\text { patient). }\end{array}$ \\
\hline & & & Authors' Conclusions: \\
\hline & & & $\begin{array}{l}\text { BEV plus bi-weekly TMZ was } \\
\text { well tolerated and may be a } \\
\text { salvage regimen to be } \\
\text { considered in a subset of } \\
\text { patients with progressive GBM. }\end{array}$ \\
\hline & & & Comments and Conclusions: \\
\hline & & & $\begin{array}{l}\text { A study without randomization } \\
\text { or control warrants Class III } \\
\text { designation. }\end{array}$ \\
\hline
\end{tabular}

Abbreviations: $\mathrm{BEV}=$ bevacizumab, $\mathrm{OS}=$ overall survival, $\mathrm{PFS}=$ progression free survival, $\mathrm{RR}=$ response rate, $\mathrm{PD}=$ progressive disease, $\mathrm{SD}=$ stable disease, $\mathrm{CR}=$ complete response, $\mathrm{PR}=$ partial response, $\mathrm{AE}$ = adverse event, $\mathrm{TMZ}$ = temozolomide, $\mathrm{GBM}=$ glioblastoma, $\mathrm{RT}$ = radiation therapy, $\mathrm{HTN}$ $=$ hypertension, $\mathrm{CHF}=$ congestive heart failure, $\mathrm{VTE}=$ venous thromboembolism, $\mathrm{CCNU}=$ lomustine, $\mathrm{PD}=$ disease progression, IRI = irinotecan 


\begin{tabular}{|c|c|c|c|}
\hline $\begin{array}{l}\text { Author } \\
\text { (year): }\end{array}$ & Description of study: & $\begin{array}{l}\text { Data } \\
\text { Class: }\end{array}$ & Conclusions: \\
\hline $\begin{array}{l}\text { Gilbert et al } \\
\text { (2017) }\end{array}$ & $\begin{array}{l}\text { Study Description: } \\
\text { A randomized phase } 2 \text { trial of BEV + either } \\
\text { irinotecan or dose-dense TMZ in } \\
\text { progressive GBM } \\
\text { Patient Population: } \\
60 \text { adult patients were enrolled on the } \\
\text { TMZ arm and } 57 \text { patients on the } \\
\text { irinotecan arm. } \\
\text { Treatment Regimen: } \\
\text { BEV } 10 \mathrm{mg} / \mathrm{kg} \text { IV every } 2 \text { weeks, irinotecan } \\
125 \mathrm{mg} / \mathrm{m}^{\wedge} 2 \text { every two weeks or TMZ } 75- \\
100 \mathrm{mg} / \mathrm{m}^{\wedge} 2 \text { days } 1-21 \text { of } 28 \text {-day cycle. }\end{array}$ & II & $\begin{array}{l}\text { Results: } \\
\text { Response to treatment: TMZ } \\
\text { had } 2 \text { CR ( } 3 \%), 9 \text { PR (16\%); } \\
\text { irinotecan had } 2 \text { CR (4\%) and } \\
13 \text { PR (24\%). } \\
\text { Toxicity: } \\
\text { TMZ had } 33 \text { (55\%) grade 3, } 11 \\
(18 \%) \text { grade } 4 \text { and } 1(2 \%) \\
\text { grade } 5 \text { (fatal) toxicities. } \\
\text { lrinotecan had } 22 \text { (39\%) grade } \\
3,7(12 \%) \text { grade } 4 \text { and } 3 \text { (5\%) } \\
\text { grade } 5 \text { toxicities. } \\
\text { Authors' Conclusions: } \\
\text { The 6-month-PFS surpassed } \\
\text { the predetermined efficacy } \\
\text { threshold for both arms, even } \\
\text { after prior TMZ exposure. } \\
\text { Toxicities were within } \\
\text { anticipated frequencies with a } \\
\text { moderately high rate of venous } \\
\text { thrombosis, moderate HTN } \\
\text { and one ICH. } \\
\text { Comments and Conclusions: } \\
\text { A randomized trial warrants } \\
\text { Class II designation. }\end{array}$ \\
\hline
\end{tabular}

Abbreviations: $\mathrm{BEV}=$ bevacizumab, $\mathrm{OS}=$ overall survival, $\mathrm{PFS}=$ progression free survival, $\mathrm{RR}=$ response rate, $\mathrm{PD}=$ progressive disease, $\mathrm{SD}=$ stable disease, $\mathrm{CR}=$ complete response, $\mathrm{PR}=$ partial response, $\mathrm{AE}=$ adverse event, $\mathrm{TMZ}=$ temozolomide, $\mathrm{GBM}=$ glioblastoma, $\mathrm{RT}$ = radiation therapy, $\mathrm{HTN}$ $=$ hypertension, $\mathrm{CHF}=$ congestive heart failure, $\mathrm{VTE}=$ venous thromboembolism, $\mathrm{CCNU}=$ lomustine, $\mathrm{PD}=$ disease progression, IRI = irinotecan 


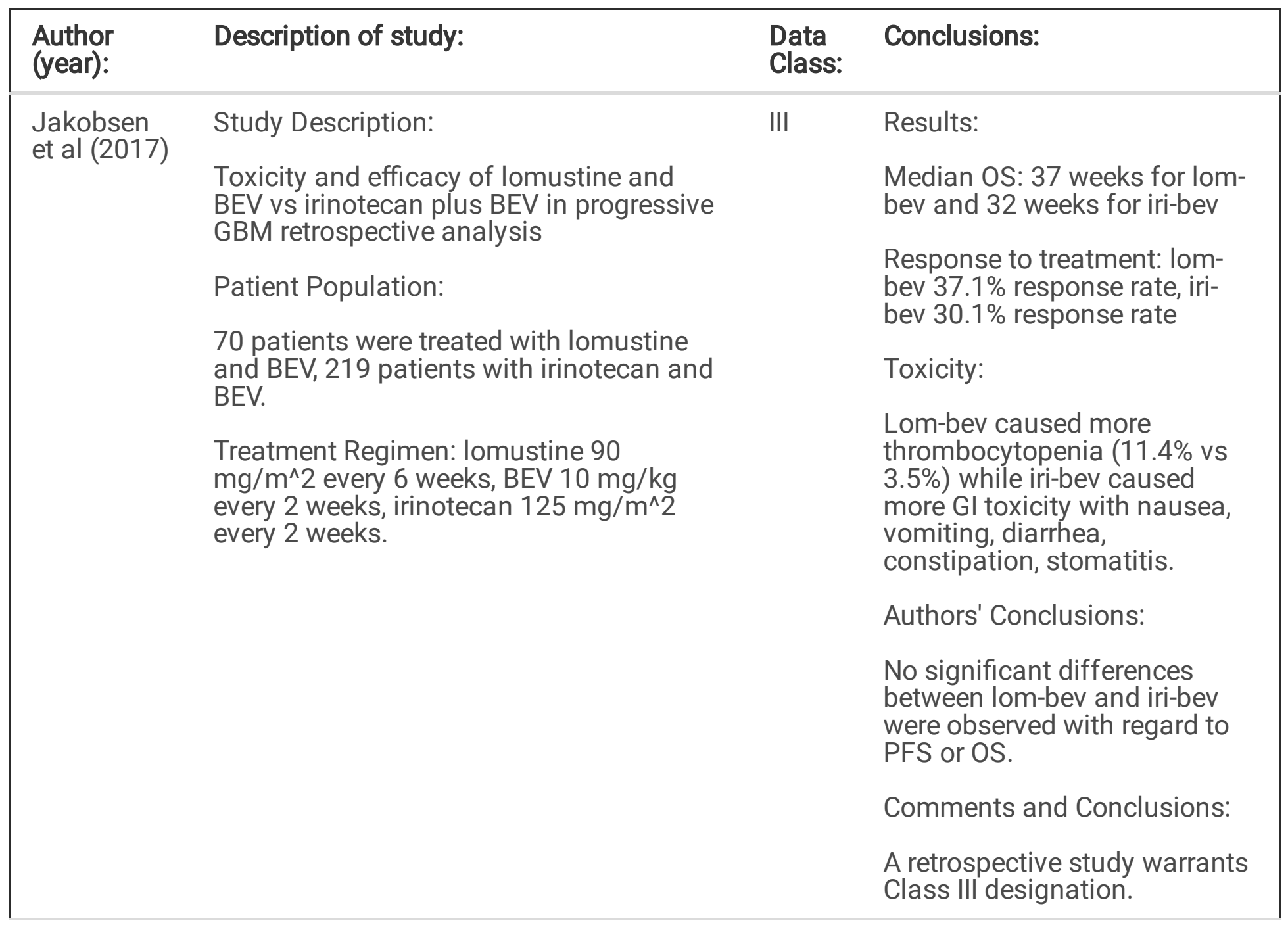

Abbreviations: $\mathrm{BEV}=$ bevacizumab, $\mathrm{OS}=$ overall survival, $\mathrm{PFS}=$ progression free survival, $\mathrm{RR}=$ response rate, $\mathrm{PD}=$ progressive disease, $\mathrm{SD}=$ stable disease, $\mathrm{CR}=$ complete response, $\mathrm{PR}=$ partial response, $\mathrm{AE}=$ adverse event, $\mathrm{TMZ}=$ temozolomide, $\mathrm{GBM}=$ glioblastoma, $\mathrm{RT}$ = radiation therapy, $\mathrm{HTN}$ $=$ hypertension, $\mathrm{CHF}=$ congestive heart failure, $\mathrm{VTE}=$ venous thromboembolism, $\mathrm{CCNU}=$ lomustine, $\mathrm{PD}=$ disease progression, IRI = irinotecan 


\begin{tabular}{|c|c|c|c|}
\hline $\begin{array}{l}\text { Author } \\
\text { (year): }\end{array}$ & Description of study: & $\begin{array}{l}\text { Data } \\
\text { Class: }\end{array}$ & Conclusions: \\
\hline \multirow{11}{*}{$\begin{array}{l}\text { Peters et al } \\
(2017)\end{array}$} & Study Description: & III & Results: \\
\hline & \multirow{2}{*}{$\begin{array}{l}\text { Phase } 1 / 2 \text { vorinostat, BEV and daily TMZ } \\
\text { for progressive malignant gliomas. }\end{array}$} & & Median OS 12.5 mos \\
\hline & & & \multirow{2}{*}{$\begin{array}{l}\text { Response to treatment: PFS6 } \\
\text { was } 53.8 \%\end{array}$} \\
\hline & Patient Population: & & \\
\hline & \multirow{2}{*}{$\begin{array}{l}\text { Phase } 1 \text { was a mixed high-grade glioma } \\
\text { population of } 9 \text { patients, phase } 2 \text { included } \\
39 \text { patients with progressive GBM. }\end{array}$} & & Toxicity: \\
\hline & & & \multirow{2}{*}{$\begin{array}{l}\text { Most common grade } 3 \text { or } \\
\text { higher complications included } \\
\text { neutropenia (4), elevated ALT } \\
\text { (2), fatigue (2), diarrhea (2), } \\
\text { hyponatremia (2), } \\
\text { hyperglycemia (2). }\end{array}$} \\
\hline & \multirow{5}{*}{$\begin{array}{l}\text { Treatment Regimen: vorinostat } 400 \mathrm{mg} \\
\text { (one patient } 200 \mathrm{mg} \text { in error), BEV } 10 \\
\mathrm{mg} / \mathrm{kg} \text { every other week starting on day } 1 \\
\text { with TMZ } 50 \mathrm{mg} / \mathrm{m}^{\wedge} 2 / \text { day and vorinostat } \\
400 \mathrm{mg} \text { days } 1-7 \text { and days } 15-21 \text { of } \\
\text { each } 28 \text {-day cycle (after dose escalation } \\
\text { phase } 1 \text { determined dose). }\end{array}$} & & \\
\hline & & & Authors' Conclusions: \\
\hline & & & $\begin{array}{l}\text { While PFS6 was not } \\
\text { statistically improved beyond } \\
\text { historical controls, it is } \\
\text { important to note that this was } \\
\text { a heavily pretreated GBM } \\
\text { population and further } \\
\text { consideration is warranted in a } \\
\text { less pretreated group. }\end{array}$ \\
\hline & & & Comments and Conclusions: \\
\hline & & & $\begin{array}{l}\text { An uncontrolled trial without } \\
\text { randomization warrants Class } \\
\text { III designation. }\end{array}$ \\
\hline
\end{tabular}

Abbreviations: $\mathrm{BEV}=$ bevacizumab, $\mathrm{OS}=$ overall survival, $\mathrm{PFS}=$ progression free survival, $\mathrm{RR}=$ response rate, $\mathrm{PD}=$ progressive disease, $\mathrm{SD}=$ stable disease, $\mathrm{CR}=$ complete response, $\mathrm{PR}=$ partial response, $\mathrm{AE}=$ adverse event, $\mathrm{TMZ}$ = temozolomide, $\mathrm{GBM}=$ glioblastoma, $\mathrm{RT}$ = radiation therapy, $\mathrm{HTN}$ $=$ hypertension, $\mathrm{CHF}=$ congestive heart failure, $\mathrm{VTE}=$ venous thromboembolism, $\mathrm{CCNU}=$ lomustine, $\mathrm{PD}=$ disease progression, IRI = irinotecan 


\begin{tabular}{|c|c|c|c|}
\hline $\begin{array}{l}\text { Author } \\
\text { (year): }\end{array}$ & Description of study: & $\begin{array}{l}\text { Data } \\
\text { Class: }\end{array}$ & Conclusions: \\
\hline \multirow{11}{*}{$\begin{array}{l}\text { Wick et al } \\
\text { (2017) }\end{array}$} & Study Description: & 1 & Results: \\
\hline & Bev + Lomustine in rGBM - Phase 3 & & $\begin{array}{l}\text { Monotherapy: OS 8.6m, PFS } \\
1.5 \mathrm{~m}\end{array}$ \\
\hline & Patient Population: & & \\
\hline & $\begin{array}{l}437 \text { adult GBM patients randomized for } \\
\text { treatment in two arms of the study }\end{array}$ & & Toxicity: \\
\hline & Treatment Regimen: & & Grade 3 to 5 adverse events \\
\hline & $\begin{array}{l}\text { Patients in the monotherapy group } \\
\text { received lomustine at a dose of } 110 \mathrm{mg} \\
\text { per square meter of body surface area } \\
\text { every } 6 \text { weeks (maximum dose, } 200 \mathrm{mg} \text { ). } \\
\text { Patients in the combination group } \\
\text { received lomustine at a dose of } 90 \mathrm{mg} \text { per } \\
\text { square }\end{array}$ & & $\begin{array}{l}\text { patients in the monotherapy } \\
\text { group and in } 63.6 \% \text { of the } \\
\text { patients in the combination } \\
\text { group. Adverse events of grade } \\
3 \text { to } 5 \text { of special interest were } \\
\text { pulmonary embolism, arterial } \\
\text { hypertension, and hematologic } \\
\text { toxic effects. }\end{array}$ \\
\hline & $\begin{array}{l}\text { meter every } 6 \text { weeks (maximum dose, } 160 \\
\text { mg) }\end{array}$ & & Authors' Conclusions: \\
\hline & $\begin{array}{l}\text { plus bevacizumab at a dose of } 10 \mathrm{mg} \text { per } \\
\text { kilogram of body weight every } 2 \text { weeks. }\end{array}$ & & $\begin{array}{l}\text { Despite somewhat prolonged } \\
\text { progressionfree survival, } \\
\text { treatment with lomustine plus }\end{array}$ \\
\hline & & & $\begin{array}{l}\text { bevacizumab did not confer a } \\
\text { survival advantage over } \\
\text { treatment with lomustine alone } \\
\text { in patients with progressive } \\
\text { glioblastoma. }\end{array}$ \\
\hline & & & Comments and Conclusions: \\
\hline & & & $\begin{array}{l}\text { A large, prospective } \\
\text { randomized trial warrants } \\
\text { Class I designation. }\end{array}$ \\
\hline
\end{tabular}

Abbreviations: $\mathrm{BEV}=$ bevacizumab, $\mathrm{OS}=$ overall survival, $\mathrm{PFS}=$ progression free survival, $\mathrm{RR}=$ response rate, $\mathrm{PD}=$ progressive disease, $\mathrm{SD}=$ stable disease, $\mathrm{CR}=$ complete response, $\mathrm{PR}=$ partial response, $\mathrm{AE}$ = adverse event, $\mathrm{TMZ}$ = temozolomide, $\mathrm{GBM}=$ glioblastoma, $\mathrm{RT}$ = radiation therapy, $\mathrm{HTN}$ $=$ hypertension, $\mathrm{CHF}=$ congestive heart failure, $\mathrm{VTE}=$ venous thromboembolism, $\mathrm{CCNU}=$ lomustine, $\mathrm{PD}=$ disease progression, IRI = irinotecan 


\begin{tabular}{|c|c|c|c|}
\hline $\begin{array}{l}\text { Author } \\
\text { (year): }\end{array}$ & Description of study: & $\begin{array}{l}\text { Data } \\
\text { Class: }\end{array}$ & Conclusions: \\
\hline $\begin{array}{l}\text { Brandes et } \\
\text { al (2016) }\end{array}$ & $\begin{array}{l}\text { Study Description: } \\
\text { Phase II randomized, noncomparative trial } \\
\text { of fotemustine or bevacizumab in } \\
\text { progressive GBM. } \\
\text { Patient Population: } \\
91 \text { adult patients with progressive GBM } \\
\text { (59 BEV } 32 \text { fotemustine) } \\
\text { Treatment Regimen: } \\
\text { BEV: } 10 \mathrm{mg} / \mathrm{kg} \text { every } 2 \text { weeks; } \\
\text { fotemustine: } 75 \mathrm{mg} / \mathrm{m}^{\wedge} 2 \text { on days } 1,8 \text { and } \\
15 \text { then } 100 \mathrm{mg} / \mathrm{m}^{\wedge} 2 \text { every } 3 \text { weeks after a } \\
35 \text {-day interval }\end{array}$ & II & $\begin{array}{l}\text { Results: } \\
\text { Median OS: } 7.3 \text { mos BEV, } 8.7 \\
\text { mos fotemustine } \\
\text { Response to treatment: } \\
\text { Response rates by RANO were } \\
29 \% \text { for BEV and 9\% for } \\
\text { fotemustine. } \\
\text { Toxicity: } \\
\text { Toxicity profiles were in line } \\
\text { with known BEV and } \\
\text { fotemustine toxicities with } \\
\text { serious AE in } 11 \text { BEV (18.6\%) } \\
\text { patients and } 3 \text { (9.4\%) } \\
\text { fotemustine patients. } \\
\text { Authors' Conclusions: } \\
\text { single-agent BEV may have a } \\
\text { role in patients with } \\
\text { progressive GBM. } \\
\text { Comments and Conclusions: } \\
\text { A randomized controlled trial } \\
\text { with a moderate number of } \\
\text { patients warrants Class II } \\
\text { designation. }\end{array}$ \\
\hline
\end{tabular}

Abbreviations: $\mathrm{BEV}=$ bevacizumab, $\mathrm{OS}=$ overall survival, $\mathrm{PFS}=$ progression free survival, $\mathrm{RR}=$ response rate, $\mathrm{PD}=$ progressive disease, $\mathrm{SD}=$ stable disease, $\mathrm{CR}=$ complete response, $\mathrm{PR}=$ partial response, $\mathrm{AE}=$ adverse event, $\mathrm{TMZ}=$ temozolomide, $\mathrm{GBM}=$ glioblastoma, $\mathrm{RT}$ = radiation therapy, $\mathrm{HTN}$ $=$ hypertension, $\mathrm{CHF}=$ congestive heart failure, $\mathrm{VTE}=$ venous thromboembolism, $\mathrm{CCNU}=$ lomustine, $\mathrm{PD}=$ disease progression, IRI = irinotecan 


\begin{tabular}{|c|c|c|c|}
\hline $\begin{array}{l}\text { Author } \\
\text { (year): }\end{array}$ & Description of study: & $\begin{array}{l}\text { Data } \\
\text { Class: }\end{array}$ & Conclusions: \\
\hline \multirow{9}{*}{$\begin{array}{l}\text { Odia et al } \\
\text { (2016) }\end{array}$} & Study Description: & \multirow[t]{9}{*}{ III } & Results: \\
\hline & $\begin{array}{l}\text { Phase II trial of tandutinib plus BEV in } \\
\text { proaressive GBM }\end{array}$ & & Median OS: 11 mos \\
\hline & Patient Population: & & $\begin{array}{l}\text { Response to treatment: } 9 \text { had } \\
\text { PR. }\end{array}$ \\
\hline & $\begin{array}{l}41 \text { BEV-naïve progressive adult GBM } \\
\text { patients }\end{array}$ & & Toxicity: \\
\hline & $\begin{array}{l}\text { Treatment Regimen: tandutinib } 500 \mathrm{mg} \\
\text { twice daily and BEV } 10 \mathrm{mg} / \mathrm{kg} \text { every } 2 \\
\text { weeks starting day } 15 \text {. }\end{array}$ & & $\begin{array}{l}\text { All patients had treatment- } \\
\text { related toxicities; common } \\
\text { grade } 3 \text { or higher included HTN } \\
(17.1 \%) \text {, muscle weakness } \\
(17.1 \%), \text { lymphopenia }(14.6 \%) \text {, } \\
\text { hypophosphatemia }(9.8 \%) .\end{array}$ \\
\hline & & & Authors' Conclusions: \\
\hline & & & $\begin{array}{l}\text { Tandutinib with bevacizumab } \\
\text { was as effective but more } \\
\text { toxic than BEV monotherapy. }\end{array}$ \\
\hline & & & Comments and Conclusions: \\
\hline & & & $\begin{array}{l}\text { A study without control arm or } \\
\text { randomization warrants Class } \\
\text { III designation. }\end{array}$ \\
\hline
\end{tabular}

Abbreviations: $\mathrm{BEV}=$ bevacizumab, $\mathrm{OS}=$ overall survival, $\mathrm{PFS}=$ progression free survival, $\mathrm{RR}=$ response rate, $\mathrm{PD}=$ progressive disease, $\mathrm{SD}=$ stable disease, $\mathrm{CR}=$ complete response, $\mathrm{PR}=$ partial response, $\mathrm{AE}=$ adverse event, $\mathrm{TMZ}=$ temozolomide, $\mathrm{GBM}=$ glioblastoma, $\mathrm{RT}$ = radiation therapy, $\mathrm{HTN}$ $=$ hypertension, $\mathrm{CHF}=$ congestive heart failure, $\mathrm{VTE}=$ venous thromboembolism, $\mathrm{CCNU}=$ lomustine, $\mathrm{PD}=$ disease progression, $\mathrm{IRI}=$ irinotecan 


\begin{tabular}{|c|c|c|c|}
\hline $\begin{array}{l}\text { Author } \\
\text { (year): }\end{array}$ & Description of study: & $\begin{array}{l}\text { Data } \\
\text { Class: }\end{array}$ & Conclusions: \\
\hline $\begin{array}{l}\text { Weathers } \\
\text { et al (2016) }\end{array}$ & $\begin{array}{l}\text { Study Description: } \\
\text { Randomized phase } 2 \text { trial of standard } \\
\text { dose BEV vs low dose Bev plus lomustine } \\
\text { Patient Population: } \\
69 \text { adult patients with progressive GBM } \\
\text { Treatment Regimen: } \\
\text { BEV } 10 \mathrm{mg} / \mathrm{kg} \text { IV every two weeks } \\
\text { (standard dosing) or BEV } 5 \mathrm{mg} / \mathrm{kg} \text { IV every } \\
\text { three weeks in combination with } \\
\text { lomustine } 90 \mathrm{mg} / \mathrm{m}^{\wedge} 2 \text { every } 6 \text { weeks, } \\
\text { reduced to } 75 \mathrm{mg} / \mathrm{m}^{\wedge} 2 \text { following } 17 \text { grade } \\
3 \text { and } 7 \mathrm{grade} 4 \text { hematologic adverse } \\
\text { events in } 12 \text { patients and } 27 \text { cycles of } \\
\text { treatment. }\end{array}$ & II & $\begin{array}{l}\text { Results: } \\
\text { Median OS: BEV alone } 8.8 \\
\text { mos, BEV plus lomustine } 9.6 \\
\text { mos } \\
\text { Response to treatment: } \\
\text { Median PFS and OS was not } \\
\text { significantly longer in either } \\
\text { arm, with trial closed early for } \\
\text { futility. } \\
\text { Toxicity: } \\
\text { All toxicities are in accordance } \\
\text { with known toxicities of both } \\
\text { drugs (lomustine dose reduced } \\
\text { as under treatment regimen } \\
\text { due to hematologic toxicity). } \\
\text { Authors' Conclusions: } \\
\text { The combination of low dose } \\
\text { BEV plus lomustine was not } \\
\text { superior to standard dose BEV. } \\
\text { Comments and Conclusions: } \\
\text { A randomized phase } 2 \text { trial } \\
\text { with control warrants Class II } \\
\text { designation. }\end{array}$ \\
\hline
\end{tabular}

Abbreviations: $\mathrm{BEV}=$ bevacizumab, $\mathrm{OS}=$ overall survival, $\mathrm{PFS}=$ progression free survival, $\mathrm{RR}=$ response rate, $\mathrm{PD}=$ progressive disease, $\mathrm{SD}=$ stable disease, $\mathrm{CR}=$ complete response, $\mathrm{PR}=$ partial response, $\mathrm{AE}=$ adverse event, $\mathrm{TMZ}$ = temozolomide, $\mathrm{GBM}=$ glioblastoma, $\mathrm{RT}$ = radiation therapy, $\mathrm{HTN}$ $=$ hypertension, $\mathrm{CHF}=$ congestive heart failure, $\mathrm{VTE}=$ venous thromboembolism, $\mathrm{CCNU}=$ lomustine, $\mathrm{PD}=$ disease progression, IRI = irinotecan 


\begin{tabular}{llll}
\hline $\begin{array}{l}\text { Author } \\
\text { (year): }\end{array}$ & Description of study: & Data & Conclusions: \\
\end{tabular}

Field et al (2015)
Study Description:

multicenter, sequential, stratified, nonblinded, randomized phase 2 study in 2 parts, recruiting from 18 Australian studying carboplatin and bevacizumab

in progressive glioblastoma,

Patient Population:

122 adult patients with progressive GBM after receiving standard therapy. 106 patients were initially diagnosed with GBM, the rest with Grade I-III Gliomas that were confirmed Grade IV on recurrence

Treatment Regimen:

Eligible patients were randomized 1:1 to receive bevacizumab $10 \mathrm{mg} / \mathrm{kg}$ IV every 2 weeks plus carboplatin AUC 5 every 4 weeks (4 weeks was deemed to be the length of one cycle), or bevacizumab monotherapy at the same

dose (Part 1). Study therapy continued until progressive disease, unacceptable toxicity, participant withdrawal, noncompliance with protocol guidelines, or death.

\section{II}

Results:

PFS6 15\% for combination therapy, $18 \%$ monotherapy

median PFS $3.5 \mathrm{~m}$ for both

median OS $6.9 \mathrm{~m}$ combination, $7.5 \mathrm{~m}$ mono

Toxicity:

most common - fatigue, anemia, neurological symptoms/signs, hypertension, nausea, thrombocytopenia, constipation. 2 deaths, one to $\mathrm{ICH}$, another to bowel perforation, both on combo therapy.

Authors' Conclusions:

In summary, we did not find that the combination of bevacizumab and chemotherapy resulted in additional PFS or OS benefit compared with bevacizumab monotherapy in progressive

GBM. Hematologic toxicities were more common in the combination arm but were generally manageable, and preliminary analysis of QOL data suggests no differences between arms

while patients are on treatment.

Comments and Conclusions:

A randomized control trial warrants Class II designation.

Abbreviations: $\mathrm{BEV}=$ bevacizumab, $\mathrm{OS}=$ overall survival, $\mathrm{PFS}=$ progression free survival, $\mathrm{RR}=$ response rate, $\mathrm{PD}=$ progressive disease, $\mathrm{SD}=$ stable disease, $\mathrm{CR}=$ complete response, $\mathrm{PR}=$ partial response, $\mathrm{AE}=$ adverse event, $\mathrm{TMZ}$ = temozolomide, $\mathrm{GBM}=$ glioblastoma, $\mathrm{RT}$ = radiation therapy, $\mathrm{HTN}$ $=$ hypertension, $\mathrm{CHF}=$ congestive heart failure, $\mathrm{VTE}=$ venous thromboembolism, $\mathrm{CCNU}=$ lomustine, $\mathrm{PD}=$ disease progression, IRI = irinotecan 


\begin{tabular}{|c|c|c|c|}
\hline $\begin{array}{l}\text { Author } \\
\text { (year): }\end{array}$ & Description of study: & $\begin{array}{l}\text { Data } \\
\text { Class: }\end{array}$ & Conclusions: \\
\hline $\begin{array}{l}\text { Heiland et } \\
\text { al (2015) }\end{array}$ & $\begin{array}{l}\text { Study Description: } \\
\text { Retrospective evaluation of BEV vs BEV } \\
\text { with lomustine in progressive GBM } \\
\text { Patient Population: } \\
17 \text { patients received BEV monotherapy } \\
\text { and } 18 \text { patients received combination } \\
\text { BEV + CCNU. Retrospectively evaluated. } \\
\text { Treatment Regimen: } \\
\text { BEV } 10 \mathrm{mg} / \mathrm{kg} \mathrm{BW} \mathrm{IV} \mathrm{every} 2 \text { weeks, } \\
\text { BEV/CCNS had BEV } 5 \mathrm{mg} / \mathrm{kg} \text { BW IV every } \\
2 \text { weeks, CCNU } 90 \mathrm{mg} / \mathrm{m}^{\wedge} 2 \text { BSA every } 6 \\
\text { weeks. }\end{array}$ & III & $\begin{array}{l}\text { Results: } \\
\text { Median OS: } 6.59 \text { mos } \\
\text { Response to treatment: } \\
\text { BEV/CCNU showed improved } \\
\text { median PFS and OS than BEV } \\
\text { monotherapy. } \\
\text { Toxicity: } \\
\text { In general, BEV monotherapy } \\
\text { or BEV/CCNS were equally } \\
\text { tolerated with rare cses of } \\
\text { grade } 3 / 4 \text { and only } 1 \text { grade } 5 \\
\text { toxicity. } \\
\text { Authors' Conclusions: } \\
\text { Last line therapy with } \\
\text { BEV/CCNU results in a longer } \\
\text { PFS and OS compared to BEV } \\
\text { monotherapy and is well- } \\
\text { tolerated. } \\
\text { Comments and Conclusions: } \\
\text { A retrospective analysis } \\
\text { warrants Class III designation. }\end{array}$ \\
\hline
\end{tabular}

Abbreviations: $\mathrm{BEV}=$ bevacizumab, $\mathrm{OS}=$ overall survival, $\mathrm{PFS}=$ progression free survival, $\mathrm{RR}=$ response rate, $\mathrm{PD}=$ progressive disease, $\mathrm{SD}=$ stable disease, $\mathrm{CR}=$ complete response, $\mathrm{PR}=$ partial response, $\mathrm{AE}=$ adverse event, $\mathrm{TMZ}=$ temozolomide, $\mathrm{GBM}=$ glioblastoma, $\mathrm{RT}$ = radiation therapy, $\mathrm{HTN}$ $=$ hypertension, $\mathrm{CHF}=$ congestive heart failure, $\mathrm{VTE}=$ venous thromboembolism, $\mathrm{CCNU}=$ lomustine, $\mathrm{PD}=$ disease progression, IRI = irinotecan 


\begin{tabular}{|c|c|c|c|}
\hline $\begin{array}{l}\text { Author } \\
\text { (year): }\end{array}$ & Description of study: & $\begin{array}{l}\text { Data } \\
\text { Class: }\end{array}$ & Conclusions: \\
\hline $\begin{array}{l}\text { Odia et al } \\
\text { (2015) }\end{array}$ & $\begin{array}{l}\text { Study Description: } \\
\text { Phase II trial of enzastaurin (LY317615) } \\
\text { plus BEV in adults with progressive } \\
\text { malignant glioma } \\
\text { Patient Population: } \\
40 \text { adult patients with progressive GBM } \\
\text { were evaluable. } \\
\text { Treatment Regimen: Patients received } \\
\text { enzastaurin as a loading dose of } 1125 \mathrm{mg} \\
\text { followed by } 500 \text { or } 875 \mathrm{mg} \text { daily for } \\
\text { patients on non-enzyme-inducing or } \\
\text { enzyme-inducing antiepileptics, } \\
\text { respectively. BEV } 10 \mathrm{mg} / \mathrm{kg} \text { IV every two } \\
\text { weeks }\end{array}$ & III & $\begin{array}{l}\text { Results: } \\
\text { Median OS: } 7.5 \text { mos } \\
\text { Response to treatment: Three } \\
\text { GBM patients were not } \\
\text { evaluable, } 8 \text { had partial or } \\
\text { complete response and } 20 \text { had } \\
\text { stable disease for } 2+\text { mos. } \\
\text { Toxicity: } \\
\text { Most common grade } 3 / 4 \\
\text { toxicities were lymphopenia } \\
(15 \%) \text { hypophosphatemia } \\
(8.8 \%) \text { and thrombotic events } \\
(7.5 \%) . \text { Two GBM patients died } \\
\text { suddenly. } \\
\text { Authors' Conclusions: } \\
\text { Enzastaurin in combination } \\
\text { with BEV is well-tolerated, with } \\
\text { response and PFS similar to } \\
\text { BEV monotherapy. } \\
\text { Comments and Conclusions: } \\
\text { With no control arm or } \\
\text { randomization, this study } \\
\text { warrants Class Ill designation. }\end{array}$ \\
\hline
\end{tabular}

Abbreviations: $\mathrm{BEV}=$ bevacizumab, $\mathrm{OS}=$ overall survival, $\mathrm{PFS}=$ progression free survival, $\mathrm{RR}=$ response rate, $\mathrm{PD}=$ progressive disease, $\mathrm{SD}=$ stable disease, $\mathrm{CR}=$ complete response, $\mathrm{PR}=$ partial response, $\mathrm{AE}$ = adverse event, $\mathrm{TMZ}$ = temozolomide, $\mathrm{GBM}=$ glioblastoma, $\mathrm{RT}$ = radiation therapy, $\mathrm{HTN}$ $=$ hypertension, $\mathrm{CHF}=$ congestive heart failure, $\mathrm{VTE}=$ venous thromboembolism, $\mathrm{CCNU}=$ lomustine, $\mathrm{PD}=$ disease progression, $\mathrm{IRI}=$ irinotecan 


\begin{tabular}{|c|c|c|c|}
\hline $\begin{array}{l}\text { Author } \\
\text { (year): }\end{array}$ & Description of study: & $\begin{array}{l}\text { Data } \\
\text { Class: }\end{array}$ & Conclusions: \\
\hline \multirow{11}{*}{$\begin{array}{l}\text { Sepulveda } \\
\text { et al (2015) }\end{array}$} & Study Description: & \multirow[t]{11}{*}{ III } & Results: \\
\hline & A phase II study of BEV with TMZ in & & Median OS: 7.3 mos \\
\hline & 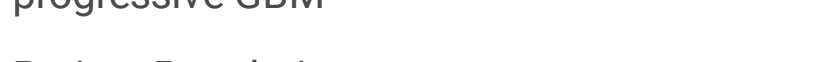 & & \multirow{3}{*}{$\begin{array}{l}\text { Response to treatment: PFS6 } \\
\text { rate of } 21.9 \%, 13 \text { patients with } \\
\text { objective response (OR), } 12 \\
\text { patients with SD. }\end{array}$} \\
\hline & Patient Population: & & \\
\hline & 32 adult patients with first recurrence GBM & & \\
\hline & Treatment Regimen: & & Toxicity: \\
\hline & \multirow[t]{5}{*}{$\begin{array}{l}\text { BEV } 10 \mathrm{mg} / \mathrm{kg} \text { IV every } 2 \text { weeks, TMZ } 150 \\
\mathrm{mg} / \mathrm{m}^{\wedge} 2 \text { days } 1-7 \text { and days } 15-21 \text { every } \\
28 \text { days. }\end{array}$} & & $\begin{array}{l}\text { Most common grade } 3 / 4 \\
\text { toxicities were lymphopenia } \\
\text { and fatigue. } 2 \text { patients had } \\
\text { grade } 3 / 4 \text { thrombosis. No } \\
\text { patient died from treatment } \\
\text { toxicity. }\end{array}$ \\
\hline & & & Authors' Conclusions: \\
\hline & & & $\begin{array}{l}\text { This regimen showed to be } \\
\text { feasible and well tolerated. } \\
\text { Further investigation is } \\
\text { warranted. }\end{array}$ \\
\hline & & & Comments and Conclusions: \\
\hline & & & $\begin{array}{l}\text { A small, nonrandomized study } \\
\text { without control warrants Class } \\
\text { III designation. }\end{array}$ \\
\hline
\end{tabular}

Abbreviations: $\mathrm{BEV}=$ bevacizumab, $\mathrm{OS}=$ overall survival, $\mathrm{PFS}=$ progression free survival, $\mathrm{RR}=$ response rate, $\mathrm{PD}=$ progressive disease, $\mathrm{SD}=$ stable disease, $\mathrm{CR}=$ complete response, $\mathrm{PR}=$ partial response, $\mathrm{AE}=$ adverse event, $\mathrm{TMZ}=$ temozolomide, $\mathrm{GBM}=$ glioblastoma, $\mathrm{RT}$ = radiation therapy, $\mathrm{HTN}$ $=$ hypertension, $\mathrm{CHF}=$ congestive heart failure, $\mathrm{VTE}=$ venous thromboembolism, $\mathrm{CCNU}=$ lomustine, $\mathrm{PD}=$ disease progression, IRI = irinotecan 


\begin{tabular}{|c|c|c|c|}
\hline $\begin{array}{l}\text { Author } \\
\text { (year): }\end{array}$ & Description of study: & $\begin{array}{l}\text { Data } \\
\text { Class: }\end{array}$ & Conclusions: \\
\hline $\begin{array}{l}\text { Rahman et } \\
\text { al (2014) }\end{array}$ & $\begin{array}{l}\text { Study Description: } \\
\text { Retrospective study of carmustine or } \\
\text { lomustine with bevacizumab in } \\
\text { progressive GBM who failed prior } \\
\text { bevacizumab } \\
\text { Patient Population: } \\
42 \text { adult patients with progressive GBM } \\
\text { who failed prior bevacizumab ( } 33 \\
\text { lomustine, } 9 \text { carmustine) } \\
\text { Treatment Regimen: lomustine doses } \\
\text { ranged from } 80-120 \mathrm{mg} / \mathrm{m}^{\wedge} 2 \text {, carmustine } \\
\text { doses ranged from } 150-200 \mathrm{mg} / \mathrm{m}^{\wedge} 2 \text {; one } \\
\text { patient on BEV and lomustine also on } \\
\text { erlotinib }\end{array}$ & III & $\begin{array}{l}\text { Results: } \\
\text { Median OS: } 18.7 \text { weeks } \\
\text { Response to treatment: RR } \\
\text { was } 44 \% \text { udring the initial BEV } \\
\text { regimen, but } 0 \% \text { during the } \\
\text { nitrosourea-containing } \\
\text { regimen. PFS6 rate was } 2.7 \% \\
\text { Toxicity: } \\
\text { Grade } 3 \text { or } 4 \text { toxicities were } \\
19 \% \text { during initial BEV regimen, } \\
\text { but } 45.2 \% \text { during the } \\
\text { combination with nitrosourea- } \\
\text { BEV regimen. } \\
\text { Authors' Conclusions: } \\
\text { The addition of lomustine or } \\
\text { carmustine to bevacizumab } \\
\text { after a patient has progressed } \\
\text { on a bevacizumab-containing } \\
\text { regimen does not appear to } \\
\text { provide benefit for most } \\
\text { patients and is associated with } \\
\text { additional toxicity with the } \\
\text { doses used in this cohort. } \\
\text { Comments and Conclusions: } \\
\text { A retrospective study warrants } \\
\text { Class III designation. }\end{array}$ \\
\hline
\end{tabular}

Abbreviations: $\mathrm{BEV}=$ bevacizumab, $\mathrm{OS}=$ overall survival, $\mathrm{PFS}=$ progression free survival, $\mathrm{RR}=$ response rate, $\mathrm{PD}=$ progressive disease, $\mathrm{SD}=$ stable disease, $\mathrm{CR}=$ complete response, $\mathrm{PR}=$ partial response, $\mathrm{AE}=$ adverse event, $\mathrm{TMZ}$ = temozolomide, $\mathrm{GBM}=$ glioblastoma, $\mathrm{RT}$ = radiation therapy, $\mathrm{HTN}$ $=$ hypertension, $\mathrm{CHF}=$ congestive heart failure, $\mathrm{VTE}=$ venous thromboembolism, $\mathrm{CCNU}=$ lomustine, $\mathrm{PD}=$ disease progression, IRI = irinotecan 


\begin{tabular}{|c|c|c|c|}
\hline $\begin{array}{l}\text { Author } \\
\text { (year): }\end{array}$ & Description of study: & $\begin{array}{l}\text { Data } \\
\text { Class: }\end{array}$ & Conclusions: \\
\hline \multirow{8}{*}{$\begin{array}{l}\text { Taal et al } \\
\text { (2014) }\end{array}$} & Study Description: & II & Results: \\
\hline & $\begin{array}{l}\text { bevacizumab or lomustine vs combination } \\
\text { of bevacizumab plus lomustine in patients } \\
\text { with progressive GBM (BELOB): } \\
\text { randomized controlled phase } 2 \text { trial }\end{array}$ & & $\begin{array}{l}\text { Median OS: } 8 \text { mos for BEV } \\
\text { alone, } 8 \text { mos for lomustine } \\
\text { alone, and } 12 \text { mos for } \\
\text { combination }\end{array}$ \\
\hline & Patient Population: & & \multirow{2}{*}{$\begin{array}{l}\text { Response to treatment: } 9 \text { mo } \\
\text { OS was } 43 \% \text { with lomustine, } \\
38 \% \text { in bevacizumab } 63 \% \text { for } \\
\text { bevacizumab and lomustine. }\end{array}$} \\
\hline & $\begin{array}{l}153 \text { adult patients from the Netherlands } \\
\text { with progressive GBM }\end{array}$ & & \\
\hline & \multirow{4}{*}{$\begin{array}{l}\text { Treatment Regimen: lomustine } 110 \\
\mathrm{mg} / \mathrm{m}^{\wedge} 2 \text { orally once every six weeks, IV } \\
\text { bevacizumab } 10 \mathrm{mg} / \mathrm{kg} \text { once every } 2 \\
\text { weeks, or combination at same doses. } \\
\text { Due to toxicity with combination } \\
\text { treatment, lomustine reduced to } 90 \\
\mathrm{mg} / \mathrm{m}^{\wedge} 2 \text { after first } 8 \text { patients. }\end{array}$} & & Authors' Conclusions: \\
\hline & & & $\begin{array}{l}\text { The combination of } \\
\text { bevacizumab and lomustine } \\
\text { met prespecified criteria for } \\
\text { assessment of this treatment } \\
\text { in further phase } 3 \text { studies. } \\
\text { However, the results in the } \\
\text { bevacizumab alone group do } \\
\text { not justify further studies of } \\
\text { this treatment. }\end{array}$ \\
\hline & & & Comments and Conclusions: \\
\hline & & & $\begin{array}{l}\text { A randomized trial with control } \\
\text { warrants Class II designation. }\end{array}$ \\
\hline
\end{tabular}

Abbreviations: $\mathrm{BEV}=$ bevacizumab, $\mathrm{OS}=$ overall survival, $\mathrm{PFS}=$ progression free survival, $\mathrm{RR}=$ response rate, $\mathrm{PD}=$ progressive disease, $\mathrm{SD}=$ stable disease, $\mathrm{CR}=$ complete response, $\mathrm{PR}=$ partial response, $\mathrm{AE}=$ adverse event, $\mathrm{TMZ}=$ temozolomide, $\mathrm{GBM}=$ glioblastoma, $\mathrm{RT}$ = radiation therapy, $\mathrm{HTN}$ $=$ hypertension, $\mathrm{CHF}=$ congestive heart failure, $\mathrm{VTE}=$ venous thromboembolism, $\mathrm{CCNU}=$ lomustine, $\mathrm{PD}=$ disease progression, IRI = irinotecan 


\begin{tabular}{|c|c|c|c|}
\hline $\begin{array}{l}\text { Author } \\
\text { (year): }\end{array}$ & Description of study: & $\begin{array}{l}\text { Data } \\
\text { Class: }\end{array}$ & Conclusions: \\
\hline \multirow{13}{*}{$\begin{array}{l}\text { Arakawa et } \\
\text { al (2013) }\end{array}$} & Study Description: & III & Results: \\
\hline & Bevacizumab in Combination & & Median OS: $6 \mathrm{~m}$ \\
\hline & with Ifosfamide, Carboplatin, and & & Toxicity: \\
\hline & $\begin{array}{l}\text { in Patients with Second Recurrence of } \\
\text { Glioblastoma }\end{array}$ & & $\begin{array}{l}3 \text { patients with grade } 3 \\
\text { lymphopenia, no other high- } \\
\text { grade events }\end{array}$ \\
\hline & Patient Population: & & Authors' Conclusions: \\
\hline & $\begin{array}{l}8 \text { adult patients with a second relapse of } \\
\text { glioblastoma }\end{array}$ & & \multirow{4}{*}{$\begin{array}{l}\text { We consider that the } \\
\text { combination of bevacizumab } \\
\text { and ice is well tolerated and } \\
\text { may derive some clinical } \\
\text { benefits in progressive } \\
\text { glioblastoma patients, in spite } \\
\text { of the limitations of our } \\
\text { analysis. Bevacizumab seems } \\
\text { to be more active with }\end{array}$} \\
\hline & Treatment Regimen: & & \\
\hline & All patients were & & \\
\hline & $\begin{array}{l}\text { diagnosed with second recurrence of } \\
\text { glioblastoma }\end{array}$ & & \\
\hline & $\begin{array}{l}\text { refractory to ice and received } 3 \text { cycles of } \\
10 \mathrm{mg} / \mathrm{kg}\end{array}$ & & $\begin{array}{l}\text { in patients with first recurrence } \\
\text { of glioblastoma }\end{array}$ \\
\hline & $\begin{array}{l}\text { bevacizumab, every two weeks, in } \\
\text { combination with }\end{array}$ & & $\begin{array}{l}\text { compared those with second } \\
\text { recurrence. }\end{array}$ \\
\hline & \multirow[t]{2}{*}{ the same regimen of ice as before. } & & Comments and Conclusions: \\
\hline & & & $\begin{array}{l}\text { A small case series without } \\
\text { control warrants Class III } \\
\text { designation. }\end{array}$ \\
\hline
\end{tabular}

Abbreviations: $\mathrm{BEV}=$ bevacizumab, $\mathrm{OS}=$ overall survival, $\mathrm{PFS}=$ progression free survival, $\mathrm{RR}=$ response rate, $\mathrm{PD}=$ progressive disease, $\mathrm{SD}=$ stable disease, $\mathrm{CR}=$ complete response, $\mathrm{PR}=$ partial response, $\mathrm{AE}=$ adverse event, $\mathrm{TMZ}$ = temozolomide, $\mathrm{GBM}=$ glioblastoma, $\mathrm{RT}$ = radiation therapy, $\mathrm{HTN}$ $=$ hypertension, $\mathrm{CHF}=$ congestive heart failure, $\mathrm{VTE}=$ venous thromboembolism, $\mathrm{CCNU}=$ lomustine, $\mathrm{PD}=$ disease progression, IRI = irinotecan 


\begin{tabular}{|c|c|c|c|}
\hline $\begin{array}{l}\text { Author } \\
\text { (year): }\end{array}$ & Description of study: & $\begin{array}{l}\text { Data } \\
\text { Class: }\end{array}$ & Conclusions: \\
\hline $\begin{array}{l}\text { Gil et al } \\
\text { (2012) }\end{array}$ & $\begin{array}{l}\text { Study Description: } \\
\text { Retrospective analysis of bevacizumab } \\
\text { plus irinotecan in progressive malignant } \\
\text { glioma. } \\
\text { Patient Population: Retrospective pooled } \\
\text { series of adult patients with progressive } \\
\text { malignant glioma ( } \mathrm{n}=87 \text { with GBM). } \\
\\
\text { Treatment Regimen: bevacizumab } 10 \\
\text { mg/kg IV + irinotecan } 125 \mathrm{mg} / \mathrm{m}^{\wedge} 2 \text { IV } \\
\text { every two weeks or } 340 \mathrm{mg} / \mathrm{m}^{\wedge} 2 \text { if } \\
\text { receiving enzyme-inducing antiepileptic } \\
\text { drugs. Treatment continued until } \\
\text { progression, unacceptable toxicity, or } 12 \\
\text { mos of treatment. }\end{array}$ & III & $\begin{array}{l}\text { Results: } \\
\text { Median OS: } 8.8 \text { mos (GBM) } \\
\text { Response to treatment: } 56 \% \text { of } \\
\text { GBM patients responded to } \\
\text { treatment. Median PFS for } \\
\text { GBM was } 5.1 \text { mos } \\
\text { Toxicity: } \\
\text { Most frequent grade } 3-4 \\
\text { toxicities were astenia (7\%), } \\
\text { diarrhea (6\%), thromboembolic } \\
\text { events (5\%). There were } 5 \text { toxic } \\
\text { deaths (4\%). } \\
\text { Authors' Conclusions: } \\
\text { Bevacizumab plus irinotecan } \\
\text { in progressive malignant } \\
\text { glioma improves responses, } \\
\text { PFS and OS compared with } \\
\text { historical data. } \\
\text { Comments and Conclusions: } \\
\text { A retrospective series warrants } \\
\text { Class IIl designation. }\end{array}$ \\
\hline
\end{tabular}

Abbreviations: $\mathrm{BEV}=$ bevacizumab, $\mathrm{OS}=$ overall survival, $\mathrm{PFS}=$ progression free survival, $\mathrm{RR}=$ response rate, $\mathrm{PD}=$ progressive disease, $\mathrm{SD}=$ stable disease, $\mathrm{CR}=$ complete response, $\mathrm{PR}=$ partial response, $\mathrm{AE}=$ adverse event, $\mathrm{TMZ}=$ temozolomide, $\mathrm{GBM}=$ glioblastoma, $\mathrm{RT}$ = radiation therapy, $\mathrm{HTN}$ $=$ hypertension, $\mathrm{CHF}=$ congestive heart failure, $\mathrm{VTE}=$ venous thromboembolism, $\mathrm{CCNU}=$ lomustine, $\mathrm{PD}=$ disease progression, IRI = irinotecan 


\begin{tabular}{|c|c|c|c|}
\hline $\begin{array}{l}\text { Author } \\
\text { (year): }\end{array}$ & Description of study: & $\begin{array}{l}\text { Data } \\
\text { Class: }\end{array}$ & Conclusions: \\
\hline \multirow{9}{*}{$\begin{array}{l}\text { Mrugala et } \\
\text { al (2012) }\end{array}$} & Study Description: & \multirow{9}{*}{$\begin{array}{l}\text { Class } \\
\text { III }\end{array}$} & Results: \\
\hline & \multirow{2}{*}{$\begin{array}{l}\text { Retrospective review of patients with } \\
\text { progressive glioblastoma treated with } \\
\text { carboplatin and Bevacizumab }\end{array}$} & & PFS-6: $40 \%$ \\
\hline & & & Mean Time to Progression: \\
\hline & Patient Population: & & \\
\hline & \multirow{2}{*}{$\begin{array}{l}14 \text { patients with progressive glioblastoma } \\
\text { treated at either first or second recurrence }\end{array}$} & & \multirow{3}{*}{$\begin{array}{l}\text { RR and Toxicity profiles for all } \\
\text { patients included, not only } \\
\text { glioblastoma recurrence }\end{array}$} \\
\hline & & & \\
\hline & Treatment Regimen: & & \\
\hline & \multirow[t]{2}{*}{$\begin{array}{l}\text { Bevacizumab } 10 \mathrm{mg} / \mathrm{kg} \text { every } 14 \text { days and } \\
\text { carboplatin at AUC of } 4-6 \mathrm{mg} / \mathrm{ml} / \mathrm{min} \text {, each } \\
\text { cycle } 6 \text { weeks long including } 3 \text { doses of } \\
\text { Bevacizumab and } 2 \text { doses of carboplatin } \\
\text { (every } 28 \text { days) }\end{array}$} & & $\begin{array}{l}\text { Author Conclusions: the } \\
\text { combination of carboplatin } \\
\text { and Bevacizumab is well } \\
\text { tolerated and active, in } \\
\text { progressive HGG patients. }\end{array}$ \\
\hline & & & $\begin{array}{l}\text { Comments and Conclusions: } \\
\text { Small cohort in a retrospective } \\
\text { review warrants a Class III } \\
\text { designation }\end{array}$ \\
\hline \multicolumn{4}{|c|}{$\begin{array}{l}\text { Abbreviations: } \mathrm{BEV}=\text { bevacizumab, } \mathrm{OS}=\text { overall survival, } \mathrm{PFS}=\text { progression free survival, } \mathrm{RR}= \\
\text { response rate, } \mathrm{PD}=\text { progressive disease, } \mathrm{SD}=\text { stable disease, } \mathrm{CR}=\text { complete response, } \mathrm{PR}=\text { partial } \\
\text { response, } \mathrm{AE}=\text { adverse event, } \mathrm{TMZ}=\mathrm{temozolomide}, \mathrm{GBM}=\text { glioblastoma, } \mathrm{RT}=\text { radiation therapy, } \mathrm{HTN} \\
=\text { hypertension, } \mathrm{CHF}=\text { congestive heart failure, } \mathrm{VTE}=\text { venous thromboembolism, } \mathrm{CCNU}=\text { lomustine, } \\
\mathrm{PD}=\text { disease progression, } \mathrm{IRI}=\text { irinotecan }\end{array}$} \\
\hline
\end{tabular}

\section{Bevacizumab with cytotoxic therapy}

There were six studies regarding BEV combined with cytotoxic therapy included in our search that met criteria for inclusion. In a small series, Arakawa et al evaluated combination therapy with ifosfamide, carboplatin, and etoposide at second recurrence, finding an mOS of 6 months.[25] In a similar study, Brenner et al added evofosfamide to BEV in BEV resistant patients compared to placebo, finding a mOS of 4.4 months with SD in $60.9 \%$ and a response in 17.4\%.[29] They found preliminary evidence of synergistic activity. Two further studies combined TMZ with BEV. Badruddoja et al combined BEV with TMZ and found a mOS of 11.0 months and PFS6 of 52\%.[26]. Sepulveda et al similarly studied BEV with TMZ and found a PFS6 of $21.9 \%$, finding the regimen was safe and possibly effective.[39] Another study by Peters et al combined Vorinostat, BEV, and TMZ at recurrence, but found their results limited by their cohort's heavy pretreatment prior to enrollment.[37] Mrugala et al retrospectively studied BEV with carboplatin at varying recurrences, finding a mOS of 9.3 months, determining some activity and tolerability of the combined therapy.[44] Ultimately, the data here regarding cytotoxic therapy with BEV at recurrence warranted Class III data designation as the studies were small and/or lacked randomization. 
However, there was one study that yielded class II evidence. Field et al randomized 122 patients with BEV and carboplatin versus BEV monotherapy.[30] PFS6 was $15 \%$ in combination therapy, $18 \%$ in monotherapy, thus they found no additional benefit with combination therapy.

\section{Nitrosoureas with Bevacizumab}

The only Class I designation was afforded to Wick et al for evaluating combination therapy with BEV and lomustine as a prospective, randomized phase III trial in 437 adult progressive glioblastoma patients.[43] Monotherapy OS was 8.6 months and PFS 1.5 months. Combination therapy OS was 9.1 months and PFS 4.2 months. The trial concluded there was not a survival advantage using combination therapy beyond that obtained with monotherapy.

Brandes et al performed a phase II randomized trial of 91 patients receiving fotemustine or BEV for progressive glioblastoma.[27] The authors concluded there may be a role for single agent BEV in progressive glioblastoma as median OS was 7.3 months with BEV and 8.7 months with fotemustine. RANO response rates were $29 \%$ with BEV and $9 \%$ with fotemustine. They had also completed a phase II randomized and double blinded study on 123 patients given BEV and Lomustine or Lomustine with placebo in first recurrence of glioblastoma.[28] At second recurrence or progression of disease, patients continued BEV or placebo. Results showed CCNU + BEV median overall survival ( $\mathrm{mOS}$ ) to be 6.4 months, PFS2 2.3 months, PFS3 2.0 months (PFS2 and PFS3 refer to the progression free survival at the second and third recurrence, respectively). There was no survival benefit and no detriment determined by the authors in continuing BEV through multiple lines of treatment. These were both designated Class II data as they were prospective, randomized trials with small cohorts.

In another randomized, controlled, Phase II study, Taal et al evaluated BEV with lomustine vs BEV monotherapy or lomustine monotherapy in 153 patients. [40] Combination therapy showed an improved OS and treatment response with 9 months OS in 63\%, surpassing the monotherapy groups. Authors concluded the combination treatment met their predetermined criteria for further evaluation. Another study by Weathers et al was a randomized phase II trial of BEV standard dose vs low dose BEV with lomustine, which found nonsuperiority of combination therapy.[42] These studies warranted Class II designation.

The remainder of the data was Class III as the cohorts were small, the data was retrospective, or the study lacked a control group. Heiland et al retrospectively reviewed BEV with lomustine against BEV monotherapy in 35 patients.[33] Median OS was 6.6 months with improved median PFS and OS in the $\mathrm{BEV}+\mathrm{CCNU}$ arm, yielding a conclusion that combination therapy as a last line therapy resulted in an improved PFS and OS compared to monotherapy. Two studies found results that showed no overall benefit. Jakobsen et al evaluated Bev + Lomustine against BEV + irinotecan. [34] They found there was no significant difference in regards to survival between the two groups. Rahman et al evaluated carmustine or lomustine with BEV after prior BEV failure and found there was no benefit in adding a nitrosourea agent to BEV treatment.[38] 
There were two studies designated Class III regarding combination therapy with fotemustine. Pasqualetti et al studied BEV with fotemustine retrospectively with varying doses of both drugs which concluded there was no rationale to exclude BEV in combination therapy after failure of second line therapies.[36] In another study that came to a similar conclusion, Vaccaro et al prospectively studied BEV with fotemustine in 13 patients.[41] Median OS was not reported in a fashion separable for only progressive glioblastoma patients, but RR showed no CR, 2 PR, 5 SD, with PFS of 3 months.

\section{ACE Inhibitors and Bevacizumab}

Gilbert et al performed the only prospective study on ACE Inhibitors combined with BEV in this group since the previous guidelines. This was a randomized phase 2 trial of BEV and irinotecan vs BEV with TMZ in 117 patients. [32] Response rate for the TMZ arm was 3\% CR and 16\% PR and for the irinotecan arm was $4 \%$ CR and $24 \%$ PR. The PFS6 for the TMZ group was $39 \%$ and for the Irinotecan group was $38.6 \%$. The PFS6 surpassed the efficacy threshold in both arms regardless of prior TMZ sensitization. As this was a prospective, randomized trial, this warrants

Class II designation.

Two retrospective studies involving irinotecan were performed. Johansen et al retrospectively reviewed 26 patients treated with BEV and Irinotecan and found a trend toward improved PFS and OS, although toxicity and mOS were not reported.[35] They did notice a beneficial effect giving irinotecan and BEV together. Gil et al completed another retrospective analysis of BEV with irinotecan in 87 patients pooling several series together.[31] Median OS was 8.8 months with Radiographic Response (RR) of $56 \%$ and a median PFS of 5.1 months. The authors concluded the combination therapy improved PFS and OS compared to historical data. These both warranted Class III designations as they were retrospective analyses.

\section{Synthesis:}

The data from the prior guidelines found a PFS6 between 18.8 and $50.3 \%$ in the included studies. Based on the update of data, the PFS6 ranged from 2.7 to $53.8 \%$, with survival data somewhat skewed in some cases using mixed populations of patients at first or second recurrence and beyond. This ultimately didn't show any significant improvement in either mOS or PFS6. The highest level data came from a Class I designated Phase III study combining nitrosoureas with BEV and ultimately finding no significant survival advantage over monotherapy with BEV.[43] Further Class II data on the topic revealed similar findings and one was actually closed early for futility. $[27 ; 28 ; 42]$ The data in general supported the utility of antiangiogenic therapy throughout multiple courses of treatment for recurrence, however there was no reliable and discernible benefit in providing combination therapies with cytotoxic agents.

Question 3: In adults with progressive glioblastoma is the use of bevacizumab as a combination therapy with targeted agents superior to standard salvage cytotoxic chemotherapy as measured by progression free survival and overall survival? 
Prior Recommendations:

In the previously published guidelines on the role of targeted therapies in the management of progressive glioblastoma in adults, bevacizumab combined with targeted therapies was reviewed and no specific recommendations were made based on a lack of strong evidence supporting a clearly defined benefit.

\section{Recommendation}

There is insufficient evidence to support a recommendation regarding this question.

\section{Study selection and characteristics of the updated search:}

The initial search strategy included 3513 candidate articles. A total of 65 articles remained for full text review. From these, 3 articles were included in the final review for question 3 and are included in Table 3 below. [45-47] 
Table 3

The role of bevacizumab with other targeted therapies.

\begin{tabular}{|c|c|c|c|}
\hline $\begin{array}{l}\text { Author } \\
\text { (year): }\end{array}$ & Description of study: & $\begin{array}{l}\text { Data } \\
\text { Class: }\end{array}$ & Conclusions: \\
\hline \multirow{11}{*}{$\begin{array}{l}\text { Lassen et al } \\
\text { (2015) }\end{array}$} & Study Description: & \multirow[t]{11}{*}{ III } & Results: \\
\hline & \multirow{2}{*}{$\begin{array}{l}\text { Phase } 1 \text { dose escalation study of } \\
\text { RO5323441 (novel antiplacental } \\
\text { growth factor monoclonal antibody) } \\
\text { in combination with bevacizumab in } \\
\text { progressive GBM. }\end{array}$} & & Median OS: 8.5 mos \\
\hline & & & \multirow{2}{*}{$\begin{array}{l}\text { Response to treatment: } 9 \text { mo os } \\
\text { was } 43 \% \text { with lomustine, } 38 \% \text { in } \\
\text { bevacizumab } 63 \% \text { for } \\
\text { bevacizumab and lomustine. }\end{array}$} \\
\hline & \multirow{3}{*}{$\begin{array}{l}\text { Patient Population: } \\
153 \text { adult patients from the } \\
\text { Netherlands with progressive GBM }\end{array}$} & & \\
\hline & & & Toxicity: \\
\hline & & & \multirow{2}{*}{$\begin{array}{l}\text { Common adverse events included } \\
\text { HTN, HA, dysphonia and fatigue. } \\
\text { Maximum tolerated dose was not } \\
\text { reached. Dose-limiting toxicities } \\
\text { occurred with two patients: grade } 3 \\
\text { miningitis with a spinal fluid leak at } \\
1250 \mathrm{mg} \text { and grade } 3 \text { cerebral } \\
\text { infarction at } 2500 \mathrm{mg} \text {. }\end{array}$} \\
\hline & \multirow[t]{5}{*}{$\begin{array}{l}\text { Treatment Regimen: Treatment of } \\
\text { R05323441 ( } 625 \mathrm{mg}, 1250 \mathrm{mg} \text {, or } \\
2500 \mathrm{mg}) \text { plus bevacizumab (10 } \\
\mathrm{mg} / \mathrm{kg} \text { ) both every two weeks. A } \\
\text { standard } 3+3 \text { dose-escalation trial } \\
\text { design was used. }\end{array}$} & & \\
\hline & & & Authors' Conclusions: \\
\hline & & & $\begin{array}{l}\text { The toxicity profile was acceptable } \\
\text { and manageable. The observed } \\
\text { clinical activity of the combination } \\
\text { does not appear to improve on that } \\
\text { obtained with single-agent } \\
\text { bevacizumab in patients with } \\
\text { progressive GBM. }\end{array}$ \\
\hline & & & Comments and Conclusions: \\
\hline & & & $\begin{array}{l}\text { An uncontrolled dose escalation } \\
\text { trial warrants Class III designation. }\end{array}$ \\
\hline
\end{tabular}

Abbreviations: $\mathrm{BEV}=$ bevacizumab, OS = overall survival, $\mathrm{PFS}=$ progression free survival, $\mathrm{PFS} 6=$ six month progression free survival, $\mathrm{RR}=$ response rate, $\mathrm{PD}=$ progressive disease, $\mathrm{SD}=$ stable disease, $\mathrm{CR}$ $=$ complete response, $\mathrm{PR}=$ partial response, $\mathrm{AE}=$ adverse event, $\mathrm{TMZ}=$ temozolomide, $\mathrm{GBM}=$ glioblastoma, $\mathrm{RT}=$ radiation therapy, $\mathrm{HTN}=$ hypertension, $\mathrm{CHF}=$ congestive heart failure, $\mathrm{VTE}=$ venous thromboembolism, $\mathrm{PE}=$ pulmonary embolism 


\begin{tabular}{|c|c|c|c|}
\hline $\begin{array}{l}\text { Author } \\
\text { (year): }\end{array}$ & Description of study: & $\begin{array}{l}\text { Data } \\
\text { Class: }\end{array}$ & Conclusions: \\
\hline \multirow{11}{*}{$\begin{array}{l}\text { Gallego et al } \\
\text { (2014) }\end{array}$} & Study Description: & III & Results: \\
\hline & \multirow{2}{*}{$\begin{array}{l}\text { Erlotinib in progressive GBM } \\
\text { patients }\end{array}$} & & 1 PR. 3 SD \\
\hline & & & PFS6-20\% \\
\hline & \multirow{2}{*}{$\begin{array}{l}\text { Patient Population: } \\
7 \text { patients within study (adult) with } \\
\text { progressive GBM }\end{array}$} & & median PFS 3.9m \\
\hline & & & Toxicity: \\
\hline & \multirow{6}{*}{$\begin{array}{l}\text { Treatment Regimen: } \\
\text { Patients treated with bevacizumab } \\
\text { received } 10 \mathrm{mg} / \mathrm{kg} \text { at days } 1 \text { and } 15 \\
\text { during radiotherapy. If applied in } \\
\text { patients who had no previous } \\
\text { progression after TMZ pre-treatment } \\
\text { a dosage of } 75 \mathrm{mg} / \mathrm{m} 2 \text { daily was } \\
\text { chosen. }\end{array}$} & & No Grade 3 or higher toxicity, no \\
\hline & & & toxicity was dermatitis. \\
\hline & & & Authors' Conclusions: \\
\hline & & & $\begin{array}{l}\text { In conclusion, we found that } \\
\text { erlotinib provided minimal } \\
\text { beneficial activity on relapse GBM } \\
\text { patients and therefore, we consider } \\
\text { that this drug is not cost-effective } \\
\text { in the treatment relapsed GMB } \\
\text { patients who express EGFRVIII and } \\
\text { PTEN as identified by IHC. }\end{array}$ \\
\hline & & & Comments and Conclusions: \\
\hline & & & $\begin{array}{l}\text { A small nonrandomized study } \\
\text { warrants Class III designation. }\end{array}$ \\
\hline
\end{tabular}

Abbreviations: $\mathrm{BEV}=$ bevacizumab, OS = overall survival, $\mathrm{PFS}=$ progression free survival, $\mathrm{PFS} 6=\mathrm{six}$ month progression free survival, $R R=$ response rate, $P D=$ progressive disease, $S D=$ stable disease, $C R$ $=$ complete response, $\mathrm{PR}=$ partial response, $\mathrm{AE}=$ adverse event, $\mathrm{TMZ}=$ temozolomide, $\mathrm{GBM}=$ glioblastoma, $\mathrm{RT}=$ radiation therapy, $\mathrm{HTN}=$ hypertension, $\mathrm{CHF}=$ congestive heart failure, $\mathrm{VTE}=$ venous thromboembolism, $\mathrm{PE}=$ pulmonary embolism 


\begin{tabular}{|c|c|c|c|}
\hline $\begin{array}{l}\text { Author } \\
\text { (year): }\end{array}$ & Description of study: & $\begin{array}{l}\text { Data } \\
\text { Class: }\end{array}$ & Conclusions: \\
\hline $\begin{array}{l}\text { Dalessandris } \\
\text { et al (2013) }\end{array}$ & $\begin{array}{l}\text { Study Description: } \\
\text { Prospective study at a single center } \\
\text { of targeted therapy based on } \\
\text { molecular profile of patients with } \\
\text { progressive GBM. } \\
\text { Patient Population: } \\
10 \text { adult patients included and } \\
\text { analyzed for VEGF overexpression } \\
\text { and EGFRvlll expression. } \\
\text { Treatment Regimen: Bevacizumab } \\
\text { was administered only to patients } \\
\text { harboring a VEGF overexpressing } \\
\text { GBM, and erlotinib was added only } \\
\text { in EGFRvIll positive GBM. } \\
\text { Bevacizumab was administered at a } \\
\text { dose of } 10 \text { mg/kg iv every } \\
2 \text { weeks in } 6 \text {-weekcycles. Erlotinib } \\
\text { was administered at a } \\
\text { dose of } 150 \text { mg/day orally (or } 300 \\
\text { mg/day in patients receiving } \\
\text { CYP3A4 enzyme-inducing anti- } \\
\text { epileptic drugs, ElAEDs). }\end{array}$ & $\begin{array}{l}\text { Class } \\
\text { III }\end{array}$ & $\begin{array}{l}\text { Results: } \\
\text { Erlotinib + BEV: } 3 \text { CR, 1PR. PFS6 } \\
\text { 100\%, OS 17m } \\
\text { Bev only: 1PR, 2CR ( } 50 \% \text { RR), PFS6 } \\
50 \% \text {, OS } 6.75 \mathrm{~m} \\
\text { Toxicity: } \\
\text { no Grade } 3 / 4 \text { events. } \\
\text { Authors' Conclusions: } \\
\text { Our results with the combination of } \\
\text { bevacizumab/erlotinib are } \\
\text { significantly better than those } \\
\text { reported by Sathornsumetee et al. } \\
\text { using bevacizumab and erlotinib in } \\
\text { molecularly unselected progressive } \\
\text { GBM. } \\
\text { Comments and Conclusions: } \\
\text { A small single-arm study without } \\
\text { controls warrants Class III } \\
\text { designation. }\end{array}$ \\
\hline $\begin{array}{l}\text { Abbreviations } \\
\text { month progre } \\
\text { = complete re } \\
\text { glioblastoma, } \\
\text { venous throm }\end{array}$ & $\begin{array}{l}\text { on free survival, } R R=\text { response rate, } \mathrm{P} \\
\text { nse, } \mathrm{PR}=\text { partial response, } \mathrm{AE}=\text { adver } \\
=\text { radiation therapy, } \mathrm{HTN}=\text { hypertensi } \\
\text { embolism, } \mathrm{PE}=\text { pulmonary embolism }\end{array}$ & $\mathrm{CHF}$ & $\begin{array}{l}\text { gression free survival, } \mathrm{PFS} 6=\text { six } \\
\text { ive disease, } \mathrm{SD}=\text { stable disease, } \mathrm{CR} \\
\mathrm{MZ}=\text { temozolomide, GBM = } \\
\text { ongestive heart failure, VTE = }\end{array}$ \\
\hline
\end{tabular}

There was only one study showing a survival benefit with combination targeted therapy and bevacizumab. D'alessandris et al performed a prospective trial evaluating erlotinib and BEV in combination vs BEV alone based on molecular profile of 10 patients with EGFRvIll expression or VEGF over expression.[47] Combination therapy showed a mOS 17 months and PFS6 of $100 \%$ while BEV monotherapy showed a PFS6 50\% and OS 6.75 months, at which point the authors concluded there was a significant survival benefit for combination therapy. As a small study lacking a control group, these were designated Class III data.

Lassen et al evaluated a novel antiplacental growth factor monoclonal antibody (R05323441) with BEV in 22 adult patients with progressive glioblastoma in a Phase I trial.[46] Median OS was 8.5 months with PFS 3.5 months in combination therapy, with the overall finding being that no significant improvement over BEV monotherapy was found in comparison to historical controls. Odia et al studied enzastaurin in combination with BEV in 40 adult patients.[45] Median OS was 7.5 months. The same group then evaluated tandutinib with BEV in 41 patients, finding nonsuperiority and slightly more toxicity than BEV 
alone.[48] All three of these studies found nonsuperiority and due to a lack of control arms in the latter two studies and the first being a dose-escalation trial, they were all deemed Class III data.

\section{Synthesis:}

In the prior guidelines published, only two trials were included that combined BEV with erlotinib or dasatinib, neither of which saw any PFS benefit, and both of which were not designated high enough class data to make a recommendation. The data reviewed since then include only Class III designations. Only one revealed significant survival benefit with erlotinib, albeit in a very small, highly specific study based on molecular profiling, while the rest showed only nonsuperiority. With the available studies and their limitations, there was insufficient high level data with consistent findings to make a treatment suggestion. This conclusion is not meant to suggest such combination studies are not worthy of further investigation and it is suggested that when available, and patients meet inclusion criteria, they be enrolled in properly designed studies of this issue.

Question 4: In adults with progressive glioblastoma is the use of targeted agents as monotherapy superior to standard salvage cytotoxic chemotherapy as measured by progression free survival and overall survival?

Prior Recommendations: In the previously published guidelines on the role of targeted therapies in the management of progressive glioblastoma in adults, targeted therapies other than BEV were reviewed and no specific recommendations were made based on a lack of strong evidence supporting a clearly defined benefit or detriment.

\section{Recommendation}

There is insufficient evidence to support a recommendation regarding this question.

\section{Study selection and characteristics of the updated search:}

The initial search strategy included 3513 candidate articles. A total of 65 articles remained for full text review. From these, 23 articles were included in the final review for question 4 and are included in Table 4 below.[49-71] 
Table 4

The role of targeted therapies other than bevacizumab in progressive GBM.

\begin{tabular}{|c|c|c|c|}
\hline $\begin{array}{l}\text { Author } \\
\text { (year): }\end{array}$ & Description of study: & $\begin{array}{l}\text { Data } \\
\text { Class: }\end{array}$ & Conclusions: \\
\hline \multirow{11}{*}{$\begin{array}{l}\text { Lassman et } \\
\text { al (2019) }\end{array}$} & Study Description: & III & Results: \\
\hline & \multirow{2}{*}{$\begin{array}{l}\text { Adult patients with progressive GBM were } \\
\text { entered in a multicenter, phase } 1 \text {, open- } \\
\text { label study of depatux-m alone or in } \\
\text { combination with other agents in GBM. }\end{array}$} & & Median OS: 7.4 mos \\
\hline & & & \multirow{3}{*}{$\begin{array}{l}\text { Response to treatment: } 58 / 60 \\
\text { patients had measurable } \\
\text { disease at baseline evaluable } \\
\text { for radiographic response. } 26 \\
\text { patients had SD, } 24 \text { PD with } \\
\text { median duration of response } \\
5.6 \text { mos, median PFS } 2.1 \text { mos. }\end{array}$} \\
\hline & Patient Population: & & \\
\hline & $\begin{array}{l}60 \text { adult patients with EGFR-amplified, } \\
\text { measurable recurreng GBM } \\
\text { (bevacizumab and nitrosourea naïve). }\end{array}$ & & \\
\hline & \multicolumn{2}{|l|}{ Treatment Regimen: } & \multirow[b]{2}{*}{$\begin{array}{l}\text { There were no new safety } \\
\text { events observed from } \\
\text { combined depatux-m and TMZ } \\
\text { compared to depatux-m } \\
\text { monotherapy or concurrent RT, } \\
\text { TMZ and depatux-m, and } \\
\text { represent common side effects } \\
\text { associated with TMZ including } \\
\text { rare thrombocytopenia. } \\
\text { Common AE include ocular } \\
\text { side effects, but no patient } \\
\text { permanently discontiunued } \\
\text { treatment while on study (nine } \\
\text { patients up to nine months) }\end{array}$} \\
\hline & \multirow[t]{5}{*}{$\begin{array}{l}\text { Depatux-m }(0.5-1.5 \mathrm{mg} / \mathrm{kg}) \text { on days } 1 \\
\text { and } 15 \text {, and TMZ }\left(150-200 \mathrm{mg} / \mathrm{m}^{\wedge} 2\right) \text { on } \\
\text { days } 1-5 \text { on a } 28 \text {-day cycle. }\end{array}$} & & \\
\hline & & & Authors' Conclusions: \\
\hline & & & $\begin{array}{l}\text { Depatux-m + TMZ displayed an } \\
\text { AE profile similar to what was } \\
\text { described previously. Antitumor } \\
\text { activity in this TMZ-refractory } \\
\text { population was encouraging. }\end{array}$ \\
\hline & & & Comments and Conclusions: \\
\hline & & & $\begin{array}{l}\text { A multicenter, nonrandomized } \\
\text { trial without control warrants } \\
\text { Class III designation. }\end{array}$ \\
\hline
\end{tabular}

Abbreviations: $\mathrm{BEV}=$ bevacizumab, OS = overall survival, $\mathrm{PFS}=$ progression free survival, $\mathrm{PFS} 6=$ six month progression free survival, $\mathrm{RR}=$ response rate, $\mathrm{PD}=$ progressive disease, $\mathrm{SD}=$ stable disease, $\mathrm{CR}$ $=$ complete response, $\mathrm{PR}=$ partial response, $\mathrm{AE}=$ adverse event, $\mathrm{TMZ}=$ temozolomide, $\mathrm{GBM}=$ glioblastoma, $\mathrm{RT}$ = radiation therapy, $\mathrm{HTN}$ = hypertension, $\mathrm{CHF}$ = congestive heart failure, $\mathrm{VTE}=$ venous thromboembolism, $\mathrm{PE}=$ pulmonary embolism, $\mathrm{ALT}=$ alanine aminotransferase, $\mathrm{AST}=$ aspartate aminotransferace, $\mathrm{GBq}=$ Gigabecquerel, $\mathrm{IHC}=$ immunohistochemistry, PD GF-R = platelet derived growth factor receptor, arg $=$ arginine 


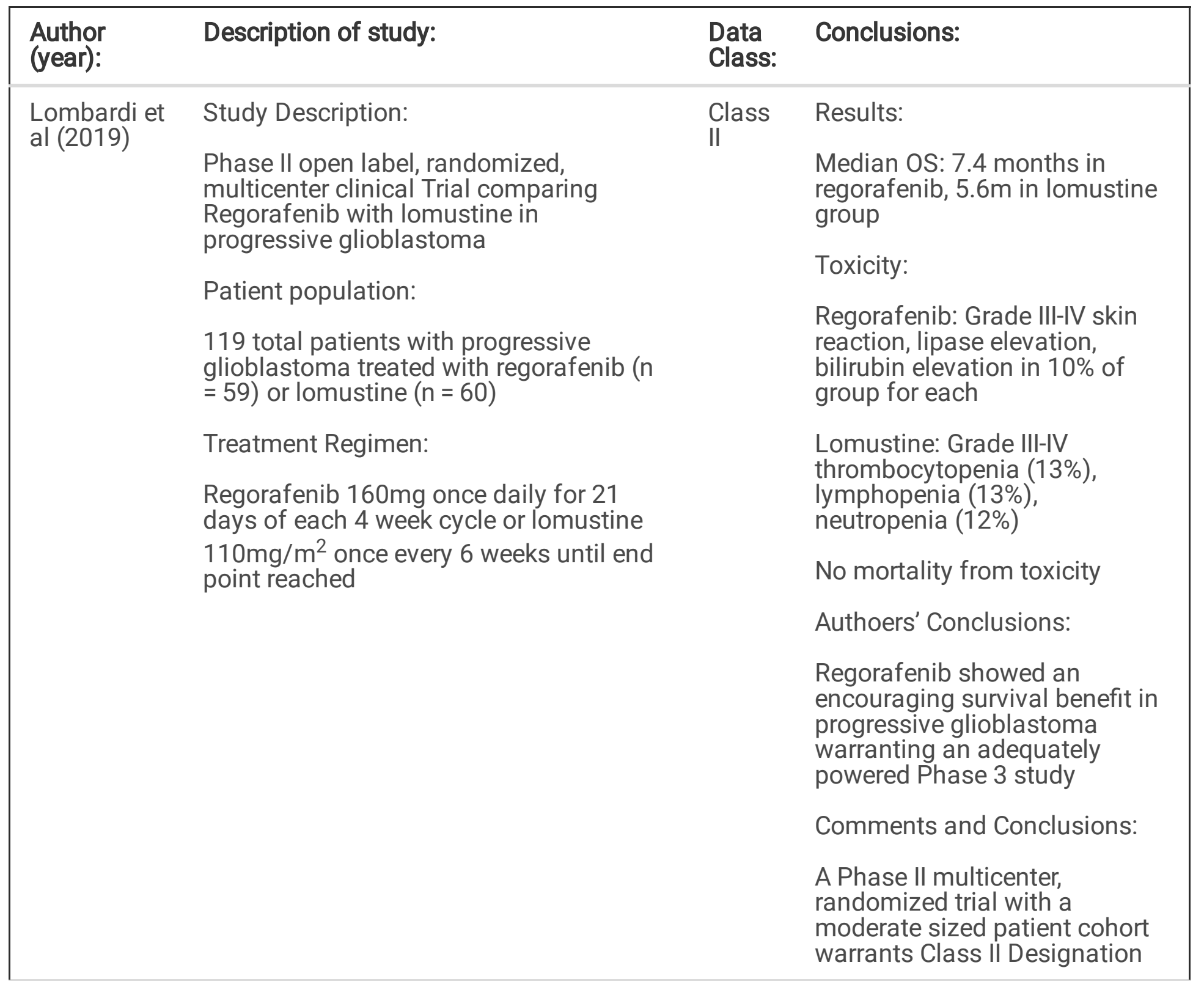

Abbreviations: $\mathrm{BEV}=$ bevacizumab, $\mathrm{OS}=$ overall survival, $\mathrm{PFS}=$ progression free survival, $\mathrm{PFS} 6=\mathrm{six}$ month progression free survival, $\mathrm{RR}=$ response rate, $\mathrm{PD}=$ progressive disease, $\mathrm{SD}=$ stable disease, $\mathrm{CR}$ = complete response, $\mathrm{PR}=$ partial response, $\mathrm{AE}=$ adverse event, $\mathrm{TMZ}=$ temozolomide, $\mathrm{GBM}=$ glioblastoma, $\mathrm{RT}$ = radiation therapy, $\mathrm{HTN}$ = hypertension, $\mathrm{CHF}$ = congestive heart failure, $\mathrm{VTE}=$ venous thromboembolism, $\mathrm{PE}=$ pulmonary embolism, $\mathrm{ALT}=$ alanine aminotransferase, $\mathrm{AST}=$ aspartate aminotransferace, $\mathrm{GBq}=$ Gigabecquerel, $\mathrm{IHC}=$ immunohistochemistry, PDGF-R = platelet derived growth factor receptor, arg $=$ arginine 


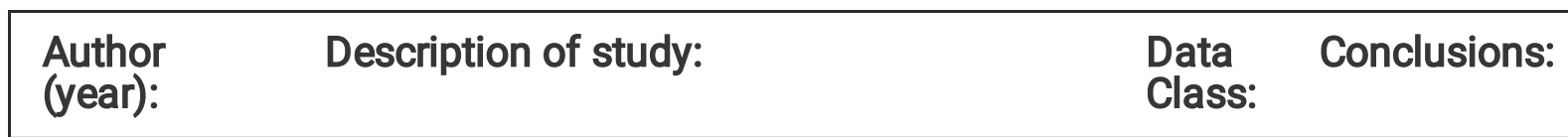

Wen et al (2019)
Study Description:

Buparlisib in Patients with Progressive

Glioblastoma Harboring

Phosphatidylinositol

3-Kinase Pathway Activation: An OpenLabel, Multicenter, Multi-Arm, Phase II

Trial

Patient Population:

65 total patients, adult with progressive GBM at first or second relapse.

Treatment Regimen:

Cohort 1-15 patients receiving pre-op buparlisib for 7-13d, received surgery, then resumed treatment. Cohort 2$100 \mathrm{mg}$ daily of buparlisib for every 28day cycle until progression of disease.

\section{Results:}

Response Rate: Cohort 1-40\% SD, $60 \%$ PD. Cohort 2-42\% SD, $54 \%$ PD, $4 \%$ not evaluable

PFS6 - Cohort $167 \%$, Cohort 2 $8 \%$

PFS $1.8 \mathrm{~m}$ v $1.7 \mathrm{~m}$. OS $17.9 \mathrm{~m}$ v $9.8 \mathrm{~m}$

Toxicity:

40\% with Grade 3-4 AE. 1.5\% $(n=1)$ with grade 4 event possibly related to treatment.3.1\% discontinued ( $\mathrm{n}$ $=2$ )

Authors' Conclusions:

This study shows that the brain-penetrant PI3K inhibitor buparlisib has minimal singleagent efficacy in patients with progressive

glioblastoma.5,20,21 Buparlisib did not meet the

primary pharmacodynamic and efficacy end points of this study. These findings are consistent with previous results wherein PI3K/mTOR inhibitors alone or in combination with cytotoxic or targeted therapies in patients with glioblastoma unselected for PI3K pathway activation showed no clinical

benefit.

Comments and Conclusions:

A multicenter trial without randomization or control warrants Class III designation.

Abbreviations: $\mathrm{BEV}=$ bevacizumab, $\mathrm{OS}=$ overall survival, $\mathrm{PFS}=$ progression free survival, $\mathrm{PFS} 6=\mathrm{six}$ month progression free survival, $\mathrm{RR}=$ response rate, $\mathrm{PD}=$ progressive disease, $\mathrm{SD}=$ stable disease, $\mathrm{CR}$ $=$ complete response, $\mathrm{PR}=$ partial response, $\mathrm{AE}=$ adverse event, $\mathrm{TMZ}=$ temozolomide, $\mathrm{GBM}=$ glioblastoma, $\mathrm{RT}=$ radiation therapy, $\mathrm{HTN}$ = hypertension, $\mathrm{CHF}=$ congestive heart failure, VTE = venous thromboembolism, $\mathrm{PE}=$ pulmonary embolism, $\mathrm{ALT}=$ alanine aminotransferase, $\mathrm{AST}=$ aspartate aminotransferace, $\mathrm{GBq}=$ Gigabecquerel, $\mathrm{IHC}=$ immunohistochemistry, PD GF-R = platelet derived growth factor receptor, arg = arginine 


\begin{tabular}{|c|c|c|c|}
\hline $\begin{array}{l}\text { Author } \\
\text { (year): }\end{array}$ & Description of study: & $\begin{array}{l}\text { Data } \\
\text { Class: }\end{array}$ & Conclusions: \\
\hline \multirow{11}{*}{$\begin{array}{l}\text { Gan et al } \\
(2018)\end{array}$} & Study Description: & \multirow[t]{11}{*}{ III } & Results: \\
\hline & $\begin{array}{l}\text { Multicenter, phase I dose escalation } \\
\text { study in patients with newly diagnosed } \\
\text { and progressive GBM }\end{array}$ & & $\begin{array}{l}\text { Median OS: } 10.7 \text { mos for } \\
\text { progressive GBM }\end{array}$ \\
\hline & Patient Population: & & \multirow{3}{*}{$\begin{array}{l}\text { Response to treatment: For } \\
\text { progressive patients, } 1 \text { had CR, } \\
2 \text { had PR, } 10 \text { had SD and } 11 \\
\text { and PD. }\end{array}$} \\
\hline & 38 adults with newly diagnosed or & & \\
\hline & 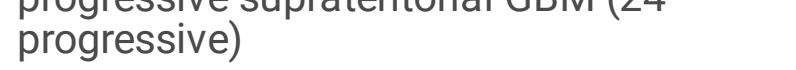 & & \\
\hline & Treatment Regimen: & & \multirow[b]{2}{*}{$\begin{array}{l}\text { The most important toxicities } \\
\text { were ocular, occuring in } 92 \% \text { of } \\
\text { patients, reducing with dose } \\
\text { reduction or interruption, } \\
\text { leading to only } 5 \% \text { study } \\
\text { discontinuation rate due to } \\
\text { toxicity ( } 5 \% \text { ). Additional } \\
\text { common AE (over } 25 \% \text { of } \\
\text { patients) included fatigue, } \\
\text { nausea, thrombocytopenia, } \\
\text { headache, and seizure. }\end{array}$} \\
\hline & \multirow{5}{*}{$\begin{array}{l}\text { A dose escalation model }(3+3) \text { was used } \\
\text { with depatux-m administered beginning } \\
\text { at } 0.5 \mathrm{mg} / \mathrm{kg} \text { with dose level increased by } \\
\text { no more than } 100 \% \text { until the first grade } \\
>/=2 \text { drug-related AE was observed. } \\
\text { Patients in one arm of recurrence } \\
\text { received TMZ }\left(150 \mathrm{mg} / \mathrm{m}^{\wedge} 2\right) \\
\text { concomitantly. Once arm C (progressive } \\
\text { GBM without TMZ) had started, RP2D of } \\
\text { depatux-m had been established at } 1.25 \\
\mathrm{mg} / \mathrm{kg} \text { with TMZ, so dosing began } \\
\text { without TMZ at this dose. Depatux-m } \\
\text { was given on days } 1 \text { and } 15 \text { of every } 28- \\
\text { day cycle. Dexamethasone }(0.1 \%) \text { eye } \\
\text { drops were administered prophylactically } \\
\text { to all patients with } 1.0 \mathrm{mg} / \mathrm{kg} \text { or higher } \\
\text { depatux-m. }\end{array}$} & & \\
\hline & & & Authors' Conclusions: \\
\hline & & & $\begin{array}{l}\text { We observed an encouraging } \\
30.8 \% \text { PFS6 in progressive } \\
\text { GBM patients treated with } \\
\text { depatux-m. Thus, further } \\
\text { evaluation of depatux-m versus } \\
\text { depatux-m + TMZ is warranted } \\
\text { in progressive GBM. }\end{array}$ \\
\hline & & & Comments and Conclusions: \\
\hline & & & $\begin{array}{l}\text { A phase } 1 \text { study in a small } \\
\text { cohort with no control warrants } \\
\text { Class III designation. }\end{array}$ \\
\hline
\end{tabular}

Abbreviations: $\mathrm{BEV}=$ bevacizumab, OS = overall survival, $\mathrm{PFS}=$ progression free survival, $\mathrm{PFS} 6=$ six month progression free survival, $\mathrm{RR}=$ response rate, $\mathrm{PD}=$ progressive disease, $\mathrm{SD}=$ stable disease, $\mathrm{CR}$ $=$ complete response, $\mathrm{PR}=$ partial response, $\mathrm{AE}=$ adverse event, $\mathrm{TMZ}=$ temozolomide, $\mathrm{GBM}=$ glioblastoma, $\mathrm{RT}$ = radiation therapy, $\mathrm{HTN}$ = hypertension, $\mathrm{CHF}$ = congestive heart failure, $\mathrm{VTE}=$ venous thromboembolism, $\mathrm{PE}=$ pulmonary embolism, $\mathrm{ALT}=$ alanine aminotransferase, $\mathrm{AST}=$ aspartate aminotransferace, $\mathrm{GBq}=$ Gigabecquerel, $\mathrm{IHC}=$ immunohistochemistry, PD GF-R = platelet derived growth factor receptor, arg $=$ arginine 


\begin{tabular}{|c|c|c|c|}
\hline $\begin{array}{l}\text { Author } \\
\text { (year): }\end{array}$ & Description of study: & $\begin{array}{l}\text { Data } \\
\text { Class: }\end{array}$ & Conclusions: \\
\hline $\begin{array}{l}\text { Krolicki, et } \\
\text { al., } 2018\end{array}$ & $\begin{array}{l}\text { Study Description: } \\
\text { Adult patients with progressive GBM in a } \\
\text { single-arm prospective trial of } 213 \mathrm{Bi}- \\
\text { DOTA-substance } \mathrm{P} \\
\text { Patient Population: } \\
\text { Twenty adult patients with histologically } \\
\text { confirmed progressive GBM, tumor } \\
\text { volume less than } 90 \mathrm{~mL} \text { without } \\
\text { hydrocephalus and KPS }>40 \text { were } \\
\text { included. } \\
\text { Treatment Regimen: } \\
\text { One or two catheters connected to a } \\
\text { subcutaneous port were placed into the } \\
\text { postsurgical cavity stereotactically or } \\
\text { intratumorally } 2-4 \text { weeks before } \\
\text { treatment. } 1 \text { to } 3 \text { injections (up to } 2.1 \\
\text { GBq) were performed depending on the } \\
\text { activity of } 213 \mathrm{Bi} \text { available from the } \\
225 \mathrm{Ac} / 213 \mathrm{Bi} \text { generator. Patients received } \\
\text { between } 1-7 \text { cycles, receiving } 213 \mathrm{Bi}- \\
\text { DOTA-SP every } 2 \text { mos. }\end{array}$ & III & $\begin{array}{l}\text { Results: } \\
\text { Median OS: } 10.9 \text { mos } \\
\text { Response to treatment: } 55 \% \text {, } \\
40 \% \text { and } 30 \% \text { of patients } \\
\text { remained alive during the } 6 \text { mo, } \\
12 \text { mo and } 18 \text { mo follow-up } \\
\text { from start of radioisotope } \\
\text { treatment. } \\
\text { Toxicity: } \\
\text { Two patients had facial } \\
\text { flushing, one had ventricular } \\
\text { enhancement on MRI without } \\
\text { symptoms (patient received } \\
\text { high dose steroids), } 10 \text { patients } \\
\text { had seizures within } 2-5 \text { days } \\
\text { of injection, one patient had } \\
\text { transient worsening of paresis. } \\
\text { Authors' Conclusions: } \\
\text { Median OS after recurrence of } \\
10.9 \text { mos compares favorably } \\
\text { to standard treatments. } \\
\text { Comments and Conclusions: } \\
\text { A small series without } \\
\text { randomization or control } \\
\text { warrants Class III designation. }\end{array}$ \\
\hline
\end{tabular}

Abbreviations: $\mathrm{BEV}=$ bevacizumab, $\mathrm{OS}=$ overall survival, $\mathrm{PFS}=$ progression free survival, $\mathrm{PFS} 6=\mathrm{six}$ month progression free survival, $\mathrm{RR}=$ response rate, $\mathrm{PD}=$ progressive disease, $\mathrm{SD}=$ stable disease, $\mathrm{CR}$ $=$ complete response, $\mathrm{PR}=$ partial response, $\mathrm{AE}=$ adverse event, $\mathrm{TMZ}=$ temozolomide, $\mathrm{GBM}=$ glioblastoma, $\mathrm{RT}$ = radiation therapy, $\mathrm{HTN}$ = hypertension, $\mathrm{CHF}$ = congestive heart failure, $\mathrm{VTE}=$ venous thromboembolism, $\mathrm{PE}=$ pulmonary embolism, $\mathrm{ALT}=$ alanine aminotransferase, $\mathrm{AST}=$ aspartate aminotransferace, $\mathrm{GBq}=$ Gigabecquerel, $\mathrm{IHC}=$ immunohistochemistry, PD GF-R = platelet derived growth factor receptor, arg $=$ arginine 


\begin{tabular}{|c|c|c|c|}
\hline $\begin{array}{l}\text { Author } \\
\text { (year): }\end{array}$ & Description of study: & $\begin{array}{l}\text { Data } \\
\text { Class: }\end{array}$ & Conclusions: \\
\hline \multirow{13}{*}{$\begin{array}{l}\text { Schiff et al } \\
(2018)\end{array}$} & Study Description: & \multirow[t]{13}{*}{ III } & Results: \\
\hline & $\begin{array}{l}\text { Phase I/II Trial of Temsirolimus and } \\
\text { Sorafenib in Treatment of }\end{array}$ & & $\begin{array}{l}\text { Arm B PFS6 } 17.1 \% \text {, PFS } 2.7 \mathrm{~m}, \\
\text { OS } 6.6 \mathrm{~m} 64 \% \text { SD, } 27 \% \text { PD, } 9 \% \\
\text { PR (3 regressed) }\end{array}$ \\
\hline & $\begin{array}{l}\text { Patients with Progressive Glioblastoma: } \\
\text { North Central Cancer Treatment Group } \\
\text { Study/Alliance N0572 }\end{array}$ & & $\begin{array}{l}\text { Arm C: PFS6 22.2\%, PFS 4.3m, } \\
\text { OS } 6.7 \mathrm{~m}\end{array}$ \\
\hline & Patient Population: & & \multirow{2}{*}{$\begin{array}{l}\text { Arm D: PFS6 9.1\%, PFS 1.9m, } \\
\text { OS } 3.9 \mathrm{~m}, 2 \% \text { regression, } 46 \% \\
\text { SD, } 51 \% \text { PD }\end{array}$} \\
\hline & \multirow{4}{*}{$\begin{array}{l}\text { Phase } 1 \text { arm A - } 12 \text { patients with } \\
\text { progressive GBM. Phase } 2 \text { arm B (VEGF } \\
\text { Naîve), } 50 \text { adult patients with progressive } \\
\text { GBM, } 46 \text { patients treated at Phase } 2 \\
\text { dose, } 3 \text { patients at phase } 2 \text { dose. Arm C } \\
-9 \text { patients treated at phase II MTD, } \\
\text { presurgical exposure. Arm D } 50 \text { patients } \\
\text { with prior VEGF treatment. }\end{array}$} & & \\
\hline & & & Toxicity: \\
\hline & & & $\begin{array}{l}\text { Grade } 3+\text { events Arm A 75.5\%, } \\
\text { B 73.9\%, C } 77.8 \%, \text { A } 66.7 \%\end{array}$ \\
\hline & & & Authors' Conclusions: \\
\hline & \multirow{5}{*}{$\begin{array}{l}\text { Treatment Regimen: } \\
\text { The phase I component (Arm A) utilized a } \\
\text { standard " } 3+3 \text { " dose escalation design. } \\
\text { The } \\
\text { starting dose was sorafenib } 200 \mathrm{mg} \\
\text { orally twice daily and temsirolimus } 25 \\
\text { mg intravenously (IV) weekly. Six } \\
\text { escalating dose levels were planned } \\
\text { beyond the starting dose (range: sorfenib } \\
200 \mathrm{mg}-400 \mathrm{mg} \text {, temsirolimus } 25 \mathrm{mg}- \\
250 \mathrm{mg} \text { - }\end{array}$} & & \multirow{4}{*}{$\begin{array}{l}\text { Limited activity of sorafenib } \\
\text { and temsirolimus in this dose } \\
\text { and schedule was observed } \\
\text { with considerable grade } 3+ \\
\text { toxicity. Significant dose } \\
\text { reductions required in this } \\
\text { treatment combination } \\
\text { compared to tolerated single- } \\
\text { agent doses may have } \\
\text { contributed to the lack of } \\
\text { efficacy. }\end{array}$} \\
\hline & & & \\
\hline & & & \\
\hline & & & \\
\hline & & & $\begin{array}{l}\text { A phase } 1 / \text { II study without } \\
\text { randomization or control } \\
\text { warrants Class III designation. }\end{array}$ \\
\hline
\end{tabular}

Abbreviations: $\mathrm{BEV}=$ bevacizumab, OS = overall survival, $\mathrm{PFS}=$ progression free survival, $\mathrm{PFS} 6=$ six month progression free survival, $\mathrm{RR}=$ response rate, $\mathrm{PD}=$ progressive disease, $\mathrm{SD}=$ stable disease, $\mathrm{CR}$ $=$ complete response, $\mathrm{PR}=$ partial response, $\mathrm{AE}=$ adverse event, $\mathrm{TMZ}=$ temozolomide, $\mathrm{GBM}=$ glioblastoma, $\mathrm{RT}$ = radiation therapy, $\mathrm{HTN}$ = hypertension, $\mathrm{CHF}$ = congestive heart failure, $\mathrm{VTE}=$ venous thromboembolism, $\mathrm{PE}=$ pulmonary embolism, $\mathrm{ALT}=$ alanine aminotransferase, $\mathrm{AST}=$ aspartate aminotransferace, $\mathrm{GBq}=$ Gigabecquerel, $\mathrm{IHC}=$ immunohistochemistry, PDGF-R = platelet derived growth factor receptor, arg $=$ arginine 


\begin{tabular}{|c|c|c|c|}
\hline $\begin{array}{l}\text { Author } \\
\text { (year): }\end{array}$ & Description of study: & $\begin{array}{l}\text { Data } \\
\text { Class: }\end{array}$ & Conclusions: \\
\hline \multirow{10}{*}{$\begin{array}{l}\text { Aiken et al. } \\
\text { (2017) }\end{array}$} & Study Description: & III & Results: \\
\hline & \multirow{2}{*}{$\begin{array}{l}\text { Phase I Clinical Trial of AXL1717 (small } \\
\text { molecule inhibitor of IGF-1b), open label, } \\
\text { single-center, with } 3+3 \text { dose escalation } \\
\text { schedule }\end{array}$} & & Median OS: 10.1m \\
\hline & & & Toxicity: \\
\hline & & & \multirow{3}{*}{$\begin{array}{l}5 \text { SAE. } 1 \text { patient with } 400 \mathrm{mg} \\
\text { BID dosing had neutropenia, } \\
\text { died of gram negative sepsis. } \\
\text { Grade } 3-4 \text { events included } 5 \\
\text { with neutropenia, } 1 \text { with } \\
\text { anemia, } 2 \text { with } \\
\text { thrombocytopenia. }\end{array}$} \\
\hline & Patient Population: & & \\
\hline & $\begin{array}{l}9 \text { adult patients with progressive } \\
\text { malignant glioma, one with gliosarcoma, } \\
\text { one with transition from AA to GBM, } 7 \\
\text { with GBM all treated with AXL1717 }\end{array}$ & & \\
\hline & Treatment Regimen: & & Authors' Conclusions: \\
\hline & \multirow[t]{3}{*}{$\begin{array}{l}\text { Patients dosed twice daily as an oral } \\
\text { suspension for cycles of } 28 \text { consecutive } \\
\text { days followed by a } 7 \text {-day holiday. }\end{array}$} & & $\begin{array}{l}\text { In conclusion, this phase I } \\
\text { clinical trial reveals that } \\
\text { AXL1717 is a promising drug } \\
\text { having the capability as a } \\
\text { single agent to produce } \\
\text { sustained clinical responses in } \\
\text { patients with relapsed } \\
\text { malignant astrocytomas. }\end{array}$ \\
\hline & & & Comments and Conclusions: \\
\hline & & & $\begin{array}{l}\text { A small, phase } 1 \text { study without } \\
\text { control warrants Class III } \\
\text { designation. }\end{array}$ \\
\hline
\end{tabular}

Abbreviations: $\mathrm{BEV}=$ bevacizumab, $\mathrm{OS}=$ overall survival, $\mathrm{PFS}=$ progression free survival, $\mathrm{PFS} 6=\mathrm{six}$ month progression free survival, $R R=$ response rate, $P D=$ progressive disease, $S D=$ stable disease, $C R$ = complete response, $\mathrm{PR}=$ partial response, $\mathrm{AE}=$ adverse event, $\mathrm{TMZ}=$ temozolomide, $\mathrm{GBM}=$ glioblastoma, $\mathrm{RT}$ = radiation therapy, $\mathrm{HTN}=$ hypertension, $\mathrm{CHF}=$ congestive heart failure, $\mathrm{VTE}=$ venous thromboembolism, $\mathrm{PE}=$ pulmonary embolism, $\mathrm{ALT}=$ alanine aminotransferase, $\mathrm{AST}=$ aspartate aminotransferace, $\mathrm{GBq}=$ Gigabecquerel, $\mathrm{IHC}=$ immunohistochemistry, PDGF-R = platelet derived growth factor receptor, arg = arginine 


\begin{tabular}{|c|c|c|c|}
\hline $\begin{array}{l}\text { Author } \\
\text { (year): }\end{array}$ & Description of study: & $\begin{array}{l}\text { Data } \\
\text { Class: }\end{array}$ & Conclusions: \\
\hline \multirow{9}{*}{$\begin{array}{l}\text { Kalpathy- } \\
\text { Cramer et al } \\
\text { (2017) }\end{array}$} & Study Description: & \multirow[t]{9}{*}{ III } & Results: \\
\hline & $\begin{array}{l}\text { Phase } 2 \text { study of tivozanib in progressive } \\
\text { GBM }\end{array}$ & & Median OS: 8.1 mos \\
\hline & Patient Population: & & $\begin{array}{l}\text { Response to treatment: } 1 \mathrm{CR}, 1 \\
\mathrm{PR}, 4 \mathrm{SD} \text { and } 4 \mathrm{PD}\end{array}$ \\
\hline & 10 adult patients with progressive GBM & & Toxicity: \\
\hline & Treatment Regimen: & & $\begin{array}{l}\text { Two patients were taken off } \\
\text { study for toxicity. }\end{array}$ \\
\hline & \multirow[t]{4}{*}{$\begin{array}{l}\text { Tivozanib } 1.5 \mathrm{mg} \text { daily, } 3 \text { weeks on } / 1 \\
\text { week off in } 28 \text {-day cycle }\end{array}$} & & Authors' Conclusions: \\
\hline & & & $\begin{array}{l}\text { Despite functional changes in } \\
\text { tumor vasculature, tivozanib } \\
\text { had limited anti-tumor activity. }\end{array}$ \\
\hline & & & Comments and Conclusions: \\
\hline & & & $\begin{array}{l}\text { A small cohort without } \\
\text { randomization or control } \\
\text { warrants Class III designation. }\end{array}$ \\
\hline
\end{tabular}

Abbreviations: $\mathrm{BEV}=$ bevacizumab, $\mathrm{OS}=$ overall survival, $\mathrm{PFS}=$ progression free survival, $\mathrm{PFS} 6=\mathrm{six}$ month progression free survival, $R R=$ response rate, $P D=$ progressive disease, $S D=$ stable disease, $C R$ = complete response, $\mathrm{PR}=$ partial response, $\mathrm{AE}=$ adverse event, $\mathrm{TMZ}=$ temozolomide, $\mathrm{GBM}=$ glioblastoma, $\mathrm{RT}$ = radiation therapy, $\mathrm{HTN}$ = hypertension, $\mathrm{CHF}$ = congestive heart failure, $\mathrm{VTE}=$ venous thromboembolism, $\mathrm{PE}=$ pulmonary embolism, $\mathrm{ALT}=$ alanine aminotransferase, $\mathrm{AST}=$ aspartate aminotransferace, $\mathrm{GBq}=$ Gigabecquerel, $\mathrm{IHC}=$ immunohistochemistry, PDGF-R = platelet derived growth factor receptor, arg = arginine 


\begin{tabular}{|c|c|c|c|}
\hline $\begin{array}{l}\text { Author } \\
\text { (year): }\end{array}$ & Description of study: & $\begin{array}{l}\text { Data } \\
\text { Class: }\end{array}$ & Conclusions: \\
\hline \multirow{11}{*}{$\begin{array}{l}\text { Phuphanich } \\
\text { et al (2017) }\end{array}$} & Study Description: & \multirow[t]{11}{*}{ III } & Results: \\
\hline & $\begin{array}{l}\text { phase II, multicenter, single-arm, open- } \\
\text { label study using MEDI-575 in } \\
\text { proqressive GBM }\end{array}$ & & $\begin{array}{l}\text { PFS6: } 15.4 \% \text {, median PFS: } \\
1.4 \mathrm{~m} \text {, median OS } 9.7 \mathrm{~m}\end{array}$ \\
\hline & Patient Population: & & $\begin{array}{l}\text { No complete/partial responses, } \\
41 \% \text { stable disease }\end{array}$ \\
\hline & $\begin{array}{l}56 \text { adult patients with progressive } \\
\text { malignant gliomas, } 51 \text { with GBM at first } \\
\text { diagnosis }\end{array}$ & & \multirow{3}{*}{$\begin{array}{l}\text { Toxicity: } \\
\text { most common - diarrhea (16\%), } \\
\text { nausea ( } 13 \% \text { ), fatigue }(13 \%) \text {. } \\
12 \text { patients with grade } 3 \text { or } \\
\text { higher, } 3 \text { hydrocephalus, } 2 \\
\text { dysphagia, } 2 \text { seizure. Serious } \\
\text { AE in } 17 \text { patients }(30 \%), 7 \\
\text { (13\%) discontinued due to } \\
\text { pneumonia, resp failure, sepsis } \\
\text { in one patient, } \\
\text { gait/aphasia/hemiparesis in } 1 \\
\text { patient, hydrocephalus and } \\
\text { AMS in } 1 \text { patient, seizure (1), } \\
\text { cerebral edema (1), confusion } \\
\text { (1), cardiac failure (1). }\end{array}$} \\
\hline & Treatment Regimen: & & \\
\hline & $\begin{array}{l}\text { Patients received intravenous MEDI- } 575 \\
25 \mathrm{mg} / \mathrm{kg} \text { over } 60 \mathrm{~min} \text { every } 21 \text { days until } \\
\text { disease progression, unacceptable } \\
\text { toxicity, or other reason for } \\
\text { discontinuation. }\end{array}$ & & \\
\hline & & & Authors' Conclusions: \\
\hline & & & $\begin{array}{l}\text { MEDI- } 575 \text { has an acceptable } \\
\text { tolerability profile but limited } \\
\text { activity in patients with a frst } \\
\text { recurrence }\end{array}$ \\
\hline & & & $\begin{array}{l}\text { of glioblastoma. Whether PDGF } \\
\text { is an appropriate target is } \\
\text { uncertain given other negative } \\
\text { studies using imatinib in } \\
\text { progressive glioblastoma }\end{array}$ \\
\hline & & & Comments and Conclusions: \\
\hline & & & $\begin{array}{l}\text { A single-arm nonrandomized } \\
\text { study without control warrants } \\
\text { Class III designation. }\end{array}$ \\
\hline
\end{tabular}

Abbreviations: $\mathrm{BEV}=$ bevacizumab, OS = overall survival, $\mathrm{PFS}=$ progression free survival, $\mathrm{PFS} 6=$ six month progression free survival, $\mathrm{RR}=$ response rate, $\mathrm{PD}=$ progressive disease, $\mathrm{SD}=$ stable disease, $\mathrm{CR}$ $=$ complete response, $\mathrm{PR}=$ partial response, $\mathrm{AE}=$ adverse event, $\mathrm{TMZ}=$ temozolomide, $\mathrm{GBM}=$ glioblastoma, $\mathrm{RT}$ = radiation therapy, $\mathrm{HTN}$ = hypertension, $\mathrm{CHF}$ = congestive heart failure, $\mathrm{VTE}=$ venous thromboembolism, $\mathrm{PE}=$ pulmonary embolism, $\mathrm{ALT}=$ alanine aminotransferase, $\mathrm{AST}=$ aspartate aminotransferace, $\mathrm{GBq}=$ Gigabecquerel, $\mathrm{IHC}=$ immunohistochemistry, PD GF-R = platelet derived growth factor receptor, arg $=$ arginine 


\begin{tabular}{|c|c|c|c|}
\hline $\begin{array}{l}\text { Author } \\
\text { (year): }\end{array}$ & Description of study: & $\begin{array}{l}\text { Data } \\
\text { Class: }\end{array}$ & Conclusions: \\
\hline \multirow{12}{*}{$\begin{array}{l}\text { Van Den } \\
\text { Bent et al } \\
\text { (2017) }\end{array}$} & Study Description: & III & Results: \\
\hline & $\begin{array}{l}\text { Efficacy of depatuxizumab mafodotin } \\
\text { (ABT-414) monotherapy }\end{array}$ & & $\begin{array}{l}\text { Response Rate: } 41 \% \text { SD, } 52 \% \\
\text { PD, }\end{array}$ \\
\hline & $\begin{array}{l}\text { in patients with EGFR-amplified, } \\
\text { progressive glioblastoma: results }\end{array}$ & & $\begin{array}{l}\text { PFS6 } 28.8 \%, \text { PFS } 1.7 \mathrm{~m}, \text { OS } \\
9.3 \mathrm{~m}\end{array}$ \\
\hline & $\begin{array}{l}\text { from a multi-center, international study } \\
\text { (Phase } 1 \text { ) }\end{array}$ & & $\begin{array}{l}\text { EGFRvIll mutation: PFS6 } 17.2 \% \text {, } \\
\text { PFS } 1.6 \mathrm{~m}\end{array}$ \\
\hline & Patient Population: & & Toxicity: \\
\hline & $\begin{array}{l}66 \text { adult patients with EGFR amplified } \\
\text { rGBM }\end{array}$ & & $\begin{array}{l}91 \% \text { experienced ocular } A E \\
42 \% \text { experienced Grade } 3 / 4 \mathrm{AE}\end{array}$ \\
\hline & Treatment Regimen: & & Authors' Conclusions: \\
\hline & $\begin{array}{l}\text { RPTD of depatux-m monotherapy was } \\
\text { determined previously as } 1.25 \mathrm{mg} / \mathrm{kg} \text { via } \\
\text { intravenous (IV) infusion every }\end{array}$ & & $\begin{array}{l}\text { We observed in this multicenter, } \\
\text { dose expansion study that } \\
\text { depatux-m monotherapy }\end{array}$ \\
\hline & $\begin{array}{l}2 \text { weeks [25]. All patients received } 1.25 \\
\mathrm{mg} / \mathrm{kg} \text { of depatuxm via intravenous } \\
\text { infusion over } 30-40 \text { min on Days } 1 \text { and } \\
15 \text { of a } 28 \text {-day cycle }\end{array}$ & & $\begin{array}{l}\text { patients with EGFR-amplified, } \\
\text { rGBM demonstrated promising } \\
\text { efficacy and manageable } \\
\text { toxicity, indicating that further } \\
\text { study of this novel targeted } \\
\text { therapy in GBM }\end{array}$ \\
\hline & & & is justified. \\
\hline & & & Comments and Conclusions: \\
\hline & & & $\begin{array}{l}\text { A nonrandomized study } \\
\text { without control warrants Class } \\
\text { IIl designation. }\end{array}$ \\
\hline
\end{tabular}

Abbreviations: $\mathrm{BEV}=$ bevacizumab, $\mathrm{OS}=$ overall survival, $\mathrm{PFS}=$ progression free survival, $\mathrm{PFS} 6=\mathrm{six}$ month progression free survival, $\mathrm{RR}=$ response rate, $\mathrm{PD}=$ progressive disease, $\mathrm{SD}=$ stable disease, $\mathrm{CR}$ = complete response, $\mathrm{PR}=$ partial response, $\mathrm{AE}=$ adverse event, $\mathrm{TMZ}=$ temozolomide, $\mathrm{GBM}=$ glioblastoma, $\mathrm{RT}$ = radiation therapy, $\mathrm{HTN}=$ hypertension, $\mathrm{CHF}=$ congestive heart failure, $\mathrm{VTE}=$ venous thromboembolism, $\mathrm{PE}=$ pulmonary embolism, $\mathrm{ALT}=$ alanine aminotransferase, $\mathrm{AST}=$ aspartate aminotransferace, $\mathrm{GBq}=$ Gigabecquerel, $\mathrm{IHC}=$ immunohistochemistry, PDGF-R = platelet derived growth factor receptor, arg = arginine 


\begin{tabular}{|c|c|c|c|}
\hline $\begin{array}{l}\text { Author } \\
\text { (year): }\end{array}$ & Description of study: & $\begin{array}{l}\text { Data } \\
\text { Class: }\end{array}$ & Conclusions: \\
\hline \multirow{12}{*}{$\begin{array}{l}\text { Batchelor et } \\
\text { al (2016) }\end{array}$} & Study Description: & \multirow[t]{12}{*}{ III } & Results: \\
\hline & Phase 1 and 2 studies of tandutinib in & & Median OS: 8.8 mos \\
\hline & & & \multirow{3}{*}{$\begin{array}{l}\text { Response to treatment: There } \\
\text { was one complete response } \\
\text { (3\%) and } 5 \text { patients reached } \\
\text { PFS6 (16\%). }\end{array}$} \\
\hline & Patient Population: & & \\
\hline & 19 adult patients with progressive GBM & & \\
\hline & 2. & & Toxicity: \\
\hline & Treatment Regimen: & & \multirow{2}{*}{$\begin{array}{l}\text { Dose limiting toxicity occurred } \\
\text { in } 1 / 6 \text { patients at } 500 \mathrm{mg}, 1 / 6 \\
\text { at } 600 \mathrm{mg} \text {, and } 2 / 3 \text { at } 700 \mathrm{mg} \text {. } \\
\text { Toxicities included grade } 3 \\
\text { phosphorus, fatigue, } \\
\text { somnolence or weakness. }\end{array}$} \\
\hline & $\begin{array}{l}\text { Tandutinib in phase } 1 \text { was given at } 500 \text {, } \\
600 \text { and } 700 \text { mg twice daily dosing, and } \\
600 \text { mg twice daily on phase } 2 \\
\text { (maximum tolerated dose). }\end{array}$ & & \\
\hline & & & Authors' Conclusions: \\
\hline & & & $\begin{array}{l}\text { The phase } 2 \text { study was closed } \\
\text { at interim analysis due to lack } \\
\text { of efficacy, despite relevant } \\
\text { intratumoral drug } \\
\text { concentrations. }\end{array}$ \\
\hline & & & Comments and Conclusions: \\
\hline & & & $\begin{array}{l}\text { A small study without a control } \\
\text { arm warrants Class III } \\
\text { designation. }\end{array}$ \\
\hline
\end{tabular}

Abbreviations: $\mathrm{BEV}=$ bevacizumab, $\mathrm{OS}=$ overall survival, $\mathrm{PFS}=$ progression free survival, $\mathrm{PFS} 6=\mathrm{six}$ month progression free survival, $R R=$ response rate, $P D=$ progressive disease, $S D=$ stable disease, $C R$ = complete response, $\mathrm{PR}=$ partial response, $\mathrm{AE}=$ adverse event, $\mathrm{TMZ}=$ temozolomide, $\mathrm{GBM}=$ glioblastoma, $\mathrm{RT}=$ radiation therapy, $\mathrm{HTN}=$ hypertension, $\mathrm{CHF}=$ congestive heart failure, VTE = venous thromboembolism, $\mathrm{PE}=$ pulmonary embolism, $\mathrm{ALT}=$ alanine aminotransferase, $\mathrm{AST}=$ aspartate aminotransferace, $\mathrm{GBq}=$ Gigabecquerel, $\mathrm{IHC}=$ immunohistochemistry, PDGF-R = platelet derived growth factor receptor, arg = arginine 


\begin{tabular}{|c|c|c|c|}
\hline $\begin{array}{l}\text { Author } \\
\text { (year): }\end{array}$ & Description of study: & $\begin{array}{l}\text { Data } \\
\text { Class: }\end{array}$ & Conclusions: \\
\hline \multirow{12}{*}{$\begin{array}{l}\text { Brown et al } \\
\text { (2016) }\end{array}$} & \multirow{4}{*}{$\begin{array}{l}\text { Study Description: } \\
\text { multi-center randomized, two-armed, } \\
\text { double-blinded phase II study comparing } \\
\text { cediranib plus gefitinib versus cediranib } \\
\text { plus placebo in subjects with first } \\
\text { relapse/first progression of glioblastoma } \\
\text { following surgery and } \\
\text { chemoradiotherapy. }\end{array}$} & \multirow[t]{12}{*}{ II } & Results: \\
\hline & & & $\begin{array}{l}\text { median OS: } 7.2 \mathrm{~m} \text { for } \mathrm{C}+\mathrm{G} \text {, } \\
5.5 \mathrm{~m} \text { for } \mathrm{C}+\text { Placebo }\end{array}$ \\
\hline & & & $\begin{array}{l}\text { PFS: } 3.6 \mathrm{~m} \text { for } \mathrm{C}+\mathrm{G}, 2.8 \mathrm{~m} \text { for } \mathrm{C} \\
+ \text { placebo. PFS6 for both was } \\
15.8 \%\end{array}$ \\
\hline & & & \multirow{2}{*}{$\begin{array}{l}\text { No complete responses, PR in } \\
42 \% \text { of } C+G, 26 \% \text { in } C+ \\
\text { Placebo }\end{array}$} \\
\hline & Patient Population: & & \\
\hline & \multirow{3}{*}{$\begin{array}{l}38 \text { adult patients with progressive GBM } \\
\text { (after standard first line therapy) were } \\
\text { randomized to cediranib + gefitinib or } \\
\text { cediranib + placebo, } 19 \text { in each group. } \\
\text { Cediranib development was discontinued } \\
\text { midstudy resulting in premature } \\
\text { termination of recruitment. }\end{array}$} & & Toxicity: \\
\hline & & & $\begin{array}{l}16 \text { patients on } C+G \text { reported } \\
\text { Grade } 3 \text { event, } 14 \text { in } C+ \\
\text { placebo }\end{array}$ \\
\hline & & & Authors' Conclusions: \\
\hline & \multirow{4}{*}{$\begin{array}{l}\text { Treatment Regimen: } \\
\text { Patients were randomized to receive } \\
\text { cediranib plus gefitinib or cediranib plus } \\
\text { placebo. All } \\
\text { patients received } 30 \mathrm{mg} \text { cediranib } \\
\text { (AZD2171) orally every day along with a } \\
\text { daily oral dose of either } 500 \mathrm{mg} \text { gefitinib } \\
\text { or a matched placebo. Dose selection } \\
\text { was based on reported toxicity and the } \\
\text { maximum tolerated dose in the phase } 1 \\
\text { study of cediranib in combination with } \\
\text { gefitinib. }\end{array}$} & & \multirow[b]{2}{*}{$\begin{array}{l}\text { Cediranib and gefitinib in } \\
\text { combination is tolerated in } \\
\text { patients with glioblastoma. } \\
\text { Incomplete recruitment led to } \\
\text { the study being underpowered. } \\
\text { However, a trend towards } \\
\text { improved survival and } \\
\text { response rates with the } \\
\text { addition of gefitinib to } \\
\text { cediranib was observed. } \\
\text { Further studies of the } \\
\text { combination incorporating } \\
\text { EGFR and VEGF inhibition are } \\
\text { warranted. }\end{array}$} \\
\hline & & & \\
\hline & & & Comments and Conclusions: \\
\hline & & & $\begin{array}{l}\text { This was a multicenter, double- } \\
\text { blind, randomized control trial } \\
\text { that reached only Class II } \\
\text { designation due to small } \\
\text { sample size. }\end{array}$ \\
\hline
\end{tabular}

Abbreviations: $\mathrm{BEV}=$ bevacizumab, OS = overall survival, $\mathrm{PFS}=$ progression free survival, $\mathrm{PFS} 6=$ six month progression free survival, $\mathrm{RR}=$ response rate, $\mathrm{PD}=$ progressive disease, $\mathrm{SD}=$ stable disease, $\mathrm{CR}$ = complete response, $\mathrm{PR}=$ partial response, $\mathrm{AE}=$ adverse event, $\mathrm{TMZ}=$ temozolomide, $\mathrm{GBM}=$ glioblastoma, $\mathrm{RT}=$ radiation therapy, $\mathrm{HTN}=$ hypertension, $\mathrm{CHF}=$ congestive heart failure, VTE = venous thromboembolism, $\mathrm{PE}=$ pulmonary embolism, $\mathrm{ALT}=$ alanine aminotransferase, $\mathrm{AST}=$ aspartate aminotransferace, $\mathrm{GBq}=$ Gigabecquerel, $\mathrm{IHC}=$ immunohistochemistry, PDGF-R = platelet derived growth factor receptor, arg = arginine 


\begin{tabular}{|c|c|c|c|}
\hline $\begin{array}{l}\text { Author } \\
\text { (year): }\end{array}$ & Description of study: & $\begin{array}{l}\text { Data } \\
\text { Class: }\end{array}$ & Conclusions: \\
\hline \multirow{13}{*}{$\begin{array}{l}\text { Butowski et } \\
\text { al (2016) }\end{array}$} & Study Description: & III & Results: \\
\hline & \multirow{2}{*}{$\begin{array}{l}\text { Orally administered colony stimulating } \\
\text { factor } 1 \text { receptor inhibitor PLX3397 in } \\
\text { progressive glioblastoma. }\end{array}$} & & Median OS: 9.4m \\
\hline & & & PFS6: 8.8\% \\
\hline & \multirow{3}{*}{$\begin{array}{l}\text { Patient Population: } \\
37 \text { patients were enrolled, with } 13 \text { treated } \\
\text { for } 7 \text { days prior to and after a planned } \\
\text { surgical resection (Cohort } 1 \text { ) and } 24 \\
\text { treated without surgery (Cohort } 2 \text { ). }\end{array}$} & & $\begin{array}{l}\text { No partial or complete } \\
\text { response on imaging }\end{array}$ \\
\hline & & & \multirow{4}{*}{$\begin{array}{l}\text { Toxicity: } \\
12 \text { patients with Grade } 3-4 \mathrm{AE} \\
\text { likely related to study drug, } \\
\text { most commonly alkaline } \\
\text { phosphatase elevation. Only } \\
\text { reported death was attributed } \\
\text { to tumor progression. }\end{array}$} \\
\hline & & & \\
\hline & Treatment Regimen: & & \\
\hline & \multirow[t]{6}{*}{$\begin{array}{l}\text { PLX3397 was given orally } 1000 \mathrm{mg} \text { daily } \\
\text { beginning } 7 \text { days prior to surgery (Cohort } \\
\text { 1) or without surgery (Cohort 2). }\end{array}$} & & \\
\hline & & & Authors' Conclusions: \\
\hline & & & $\begin{array}{l}\text { PLX3397 is a potent inhibitor } \\
\text { of tumor-associated }\end{array}$ \\
\hline & & & $\begin{array}{l}\text { macrophages and microglia, } \\
\text { readily entered GB tumor tissue, } \\
\text { and demonstrated PD effects } \\
\text { in some patients. However, } \\
\text { there was no significant } \\
\text { improvement in efficacy in the } \\
\text { present study compared with } \\
\text { historical controls. }\end{array}$ \\
\hline & & & Comments and Conclusions: \\
\hline & & & $\begin{array}{l}\text { This phase II study had a small } \\
\text { cohort without randomization } \\
\text { or control. This warrants Class } \\
\text { III designation. }\end{array}$ \\
\hline
\end{tabular}

Abbreviations: $\mathrm{BEV}=$ bevacizumab, OS = overall survival, $\mathrm{PFS}=$ progression free survival, $\mathrm{PFS} 6=$ six month progression free survival, $\mathrm{RR}=$ response rate, $\mathrm{PD}=$ progressive disease, $\mathrm{SD}=$ stable disease, $\mathrm{CR}$ $=$ complete response, $\mathrm{PR}=$ partial response, $\mathrm{AE}=$ adverse event, $\mathrm{TMZ}=$ temozolomide, $\mathrm{GBM}=$ glioblastoma, $\mathrm{RT}=$ radiation therapy, $\mathrm{HTN}=$ hypertension, $\mathrm{CHF}=$ congestive heart failure, VTE = venous thromboembolism, $\mathrm{PE}=$ pulmonary embolism, $\mathrm{ALT}=$ alanine aminotransferase, $\mathrm{AST}=$ aspartate aminotransferace, $\mathrm{GBq}=$ Gigabecquerel, $\mathrm{IHC}=$ immunohistochemistry, PD GF-R = platelet derived growth factor receptor, arg $=$ arginine 


\begin{tabular}{|c|c|c|c|}
\hline $\begin{array}{l}\text { Author } \\
\text { (year): }\end{array}$ & Description of study: & $\begin{array}{l}\text { Data } \\
\text { Class: }\end{array}$ & Conclusions: \\
\hline \multirow{11}{*}{$\begin{array}{l}\text { Gerstner et } \\
\text { al (2015) }\end{array}$} & Study Description: & \multirow[t]{11}{*}{ III } & Results: \\
\hline & Phase I study of cediranib in combination & & Median OS: 6.5 mos \\
\hline & progressive GBM & & Response to treatment: 2 CR, 2 \\
\hline & Patient Population: & & response rate of $8.9 \%$ \\
\hline & 45 adult patients with progressive GBM & & Toxicity: \\
\hline & Treatment Regimen: & & \multirow[b]{2}{*}{$\begin{array}{l}\text { No dose limiting toxicities were } \\
\text { observed, with grade } 3 / 4 \\
\text { toxicities including elevated } \\
\text { ALT/AST, cognitive disturbance, } \\
\text { diarrhea, duodenal hemorrhage, } \\
\text { HA, HTN, decreased } \\
\text { lymphocytes, } \\
\text { hypophosphatemia, } \\
\text { thrombocytopenia, seizures, } \\
\text { abdominal cramping and } \\
\text { fatigue. }\end{array}$} \\
\hline & $\begin{array}{l}40 \text { patients enrolled in a dose expansion } \\
\text { cohort with } 20 \text { being exposed to anti- } \\
\text { VEGF therapy and } 20 \text { patients naïve. } \\
\text { Cediranib was } 30 \mathrm{mg} \text { by mouth daily and } \\
\text { cilengitide was } 2000 \text { mg IV twice weekly } \\
\text { to determine MTD. No dose-limiting } \\
\text { toxicities were observed in the first five } \\
\text { patients, so dose reductions were not } \\
\text { required. }\end{array}$ & & \\
\hline & & & Authors' Conclusions: \\
\hline & & & $\begin{array}{l}\text { The combination of cediranib } \\
\text { with cilengitide was well } \\
\text { tolerated and associated with } \\
\text { pharmacodynamic blood and } \\
\text { imaging biomarkers. However, } \\
\text { the survival and response rates } \\
\text { do not warrant further } \\
\text { development of this } \\
\text { combination. }\end{array}$ \\
\hline & & & Comments and Conclusions: \\
\hline & & & $\begin{array}{l}\text { A phase } 1 \text { study without } \\
\text { randomization or control } \\
\text { warrants Class III designation. }\end{array}$ \\
\hline
\end{tabular}

Abbreviations: $\mathrm{BEV}=$ bevacizumab, $\mathrm{OS}=$ overall survival, $\mathrm{PFS}=$ progression free survival, $\mathrm{PFS} 6=\mathrm{six}$ month progression free survival, $\mathrm{RR}=$ response rate, $\mathrm{PD}=$ progressive disease, $\mathrm{SD}=$ stable disease, $\mathrm{CR}$ = complete response, $\mathrm{PR}=$ partial response, $\mathrm{AE}=$ adverse event, $\mathrm{TMZ}=$ temozolomide, $\mathrm{GBM}=$ glioblastoma, $\mathrm{RT}$ = radiation therapy, $\mathrm{HTN}=$ hypertension, $\mathrm{CHF}=$ congestive heart failure, VTE = venous thromboembolism, $\mathrm{PE}=$ pulmonary embolism, $\mathrm{ALT}=$ alanine aminotransferase, $\mathrm{AST}=$ aspartate aminotransferace, $\mathrm{GBq}=$ Gigabecquerel, $\mathrm{IHC}=$ immunohistochemistry, PDGF-R = platelet derived growth factor receptor, arg = arginine 


\begin{tabular}{|c|c|c|c|}
\hline $\begin{array}{l}\text { Author } \\
\text { (year): }\end{array}$ & Description of study: & $\begin{array}{l}\text { Data } \\
\text { Class: }\end{array}$ & Conclusions: \\
\hline $\begin{array}{l}\text { Jia et al } \\
\text { (2015) }\end{array}$ & $\begin{array}{l}\text { Study Description: } \\
\text { Prospective nonrandomized trial of adult } \\
\text { patients with progressive malignant } \\
\text { supratentorial glioma } \\
\text { Patient Population: } \\
\text { Progressive high-grade glioma patients } \\
\text { ( } 19 \text { with progressive GBM) } \\
\text { Treatment Regimen: } \\
\text { Retinoic acid naphthalene triazole was } \\
\text { given orally at a dosage of } 50 \text { or } 80 \\
\text { mg/m^ } 2 \text { once daily for } 3 \text { weeks followed } \\
\text { by no treatment for one week, three } \\
\text { patients received } 3 \text { days of } 100 \mathrm{mg} / \mathrm{m}^{\wedge} 2 \\
\text { but dose reduced to } 80 \text { due to toxicity. } \\
\text { Treatment continued until disease } \\
\text { progression, toxicity or withdrawal of } \\
\text { consent. }\end{array}$ & III & $\begin{array}{l}\text { Results: } \\
\text { Median OS: } 69 \text { weeks } \\
\text { Response to treatment: } 0 \text { PR } 5 \\
\text { minor response (less than } 25 \% \\
\text { decrease in lesion on imaging), } \\
6 \text { SD and } 8 \text { PD. Median PFS } 28 \\
\text { weeks. } \\
\text { Toxicity (all patients): } \\
\text { Skin erythema, cheilitis and } \\
\text { conjunctivitis in most patients, } \\
\text { requiring dose reduction in } \\
\text { patients over } 80 \text { mg/m² } \\
\text { Authors' Conclusions: } \\
\text { Retinoic acid naphthalene } \\
\text { triazole seems to have a role in } \\
\text { the treatment of progressive } \\
\text { malignant glioma by increasing } \\
\text { median survival and keeping } \\
45 \% \text { of patients progression- } \\
\text { free for six months. } \\
\text { Comments and Conclusions: } \\
\text { A nonrandomized trial without } \\
\text { control in a small cohort } \\
\text { warrants Class III designation. }\end{array}$ \\
\hline
\end{tabular}

Abbreviations: $\mathrm{BEV}=$ bevacizumab, $\mathrm{OS}=$ overall survival, $\mathrm{PFS}=$ progression free survival, $\mathrm{PFS} 6=\mathrm{six}$ month progression free survival, $R R=$ response rate, $P D=$ progressive disease, $S D=$ stable disease, $C R$ = complete response, $\mathrm{PR}=$ partial response, $\mathrm{AE}=$ adverse event, $\mathrm{TMZ}=$ temozolomide, $\mathrm{GBM}=$ glioblastoma, $\mathrm{RT}$ = radiation therapy, $\mathrm{HTN}$ = hypertension, $\mathrm{CHF}=$ congestive heart failure, VTE = venous thromboembolism, $\mathrm{PE}=$ pulmonary embolism, $\mathrm{ALT}=$ alanine aminotransferase, $\mathrm{AST}=$ aspartate aminotransferace, $\mathrm{GBq}=$ Gigabecquerel, $\mathrm{IHC}=$ immunohistochemistry, PDGF-R = platelet derived growth factor receptor, arg $=$ arginine 


\begin{tabular}{|c|c|c|c|}
\hline $\begin{array}{l}\text { Author } \\
\text { (year): }\end{array}$ & Description of study: & $\begin{array}{l}\text { Data } \\
\text { Class: }\end{array}$ & Conclusions: \\
\hline $\begin{array}{l}\text { Lassman et } \\
\text { al (2015) }\end{array}$ & $\begin{array}{l}\text { Study Description: } \\
\text { Adult patients with progressive GBM in a } \\
\text { single arm dose escalation Phase } 2 \text { trial. } \\
\text { Patient Population: } \\
50 \text { patients with bevacizumab-naïve } \\
\text { progressive GBM harboring } \\
\text { overexpression of SRC, PDGFR, EPHA2 } \\
\text { and/or c-KIT were treated in a single arm } \\
\text { Phase } 2 \text { trial of dasatinib as } \\
\text { monotherapy. } \\
\text { Treatment Regimen: } \\
\text { Dasatinib was initiated at } 100 \text { mg twice } \\
\text { daily until disease progression or } \\
\text { intolerable toxicity, cycle defined as } 28 \\
\text { days although treatment was continuous } \\
\text { for Stage } 1 \text { patients (21) until disease } \\
\text { progression or intolerable toxicity. Stage } \\
\text { 1B patients had dose escalation } \\
\text { escalation by } 50 \text { mg per day per cycle up } \\
\text { to a maximum of } 400 \text { mg total per day, } \\
\text { absent intolerable toxicity. }\end{array}$ & III & $\begin{array}{l}\text { Results: } \\
\text { Median OS: } 7.9 \text { mos } \\
\text { Response to treatment: Of } 50 \\
\text { patients, best response was } 12 \\
\text { SD while } 36 \text { had PD. There } \\
\text { were no responses. } \\
\text { Toxicity: } \\
\text { Grade } 3 \text { or higher toxicities } \\
\text { included: } 9 \text { patients with } \\
\text { hematologic toxicities, } 1 \\
\text { cardiac toxicity, } 6 \text { fatigue, } 6 \\
\text { insomnia, one pyrexia, } 3 \text { GI } \\
\text { toxicities, } 2 \text { hemorrhages, } 7 \\
\text { metabolic toxicities, } 2 \\
\text { musculoskeletal toxicities, } 2 \\
\text { neurological toxicities, and one } \\
\text { pain. } \\
\text { Authors' Conclusions: } \\
\text { Intraparticipant dose escalation } \\
\text { was feasible, but dasatinib was } \\
\text { ineffective in progressive GBM. } \\
\text { Comments and Conclusions: } \\
\text { A trial without randomization or } \\
\text { control arm warrants Class III } \\
\text { designation. }\end{array}$ \\
\hline
\end{tabular}

Abbreviations: $\mathrm{BEV}=$ bevacizumab, OS = overall survival, $\mathrm{PFS}=$ progression free survival, $\mathrm{PFS} 6=$ six month progression free survival, $R R=$ response rate, $P D=$ progressive disease, $S D=$ stable disease, $C R$ $=$ complete response, $\mathrm{PR}=$ partial response, $\mathrm{AE}=$ adverse event, $\mathrm{TMZ}=$ temozolomide, $\mathrm{GBM}=$ glioblastoma, $\mathrm{RT}$ = radiation therapy, $\mathrm{HTN}$ = hypertension, $\mathrm{CHF}=$ congestive heart failure, VTE = venous thromboembolism, $\mathrm{PE}=$ pulmonary embolism, $\mathrm{ALT}=$ alanine aminotransferase, $\mathrm{AST}=$ aspartate aminotransferace, $\mathrm{GBq}=$ Gigabecquerel, $\mathrm{IHC}=$ immunohistochemistry, PDGF-R = platelet derived growth factor receptor, arg $=$ arginine 


\begin{tabular}{|c|c|c|c|}
\hline $\begin{array}{l}\text { Author } \\
\text { (year): }\end{array}$ & Description of study: & $\begin{array}{l}\text { Data } \\
\text { Class: }\end{array}$ & Conclusions: \\
\hline $\begin{array}{l}\text { Pitz et al. } \\
\text { (2015) }\end{array}$ & $\begin{array}{l}\text { Study Description: } \\
\text { multicenter, open-label, single arm, phase } \\
\text { Il study using PX-866 in progressive GBM } \\
\text { Patient Population: } \\
33 \text { adult patients with progressive GBM } \\
\text { Treatment Regimen: } \\
\text { Eligible patients were given } 8 \text { mg of PX- } \\
866 \text { by mouth daily, } \\
\text { starting within } 2 \text { days of registration. } \\
\text { Each cycle was } 8 \text { weeks } \\
\text { long. }\end{array}$ & III & $\begin{array}{l}\text { Results: } \\
\text { Response: } 73 \% \text { progressive } \\
\text { disease, } 3 \% \text { partial response, } \\
24 \% \text { stable (maintained } 6.3 m \text { ) } \\
\text { PFS6 17\%, } \\
\text { Toxicity: } \\
6 \text { discontinued therapy for } \\
\text { disease toxicity (ALT elevation, } \\
1 \text { allergic rxn), } 27 \text { for disease } \\
\text { progression. Grade } 3-6 \text { with } \\
\text { lymphopenia, } 4 \text { with ALT } \\
\text { elevation, } 6 \text { with AST elevation, } \\
1 \text { with hyponatremia, } 5 \text { with } \\
\text { diarrhea, } 1 \text { with nausea, } 1 \text { with } \\
\text { vomiting, } 2 \text { with fatigue, } 1 \\
\text { weakness, } 1 \text { thromboembolic } \\
\text { event. Grade } 4: 1 \text { lymphopenia, } \\
4 \text { ALT, } 1 \text { AST } \\
\text { Authors' Conclusions: } \\
\text { This agent was reasonably well } \\
\text { tolerated but did not meet the } \\
\text { predefined efficacy endpoints. } \\
\text { Despite this, a notable portion } \\
\text { of the participants had } \\
\text { prolonged stable disease while } \\
\text { on PX-866. } \\
\text { Comments and Conclusions: } \\
\text { A single-arm nonrandomized } \\
\text { study without control warrants } \\
\text { Class III designation. }\end{array}$ \\
\hline
\end{tabular}

Abbreviations: $\mathrm{BEV}=$ bevacizumab, OS = overall survival, $\mathrm{PFS}=$ progression free survival, $\mathrm{PFS} 6=$ six month progression free survival, $\mathrm{RR}=$ response rate, $\mathrm{PD}=$ progressive disease, $\mathrm{SD}=$ stable disease, $\mathrm{CR}$ = complete response, $\mathrm{PR}=$ partial response, $\mathrm{AE}=$ adverse event, $\mathrm{TMZ}=$ temozolomide, $\mathrm{GBM}=$ glioblastoma, $\mathrm{RT}$ = radiation therapy, $\mathrm{HTN}=$ hypertension, $\mathrm{CHF}=$ congestive heart failure, $\mathrm{VTE}=$ venous thromboembolism, $\mathrm{PE}=$ pulmonary embolism, $\mathrm{ALT}=$ alanine aminotransferase, $\mathrm{AST}=$ aspartate aminotransferace, $\mathrm{GBq}=$ Gigabecquerel, $\mathrm{IHC}=$ immunohistochemistry, PDGF-R = platelet derived growth factor receptor, arg = arginine 


\begin{tabular}{|c|c|c|c|}
\hline $\begin{array}{l}\text { Author } \\
\text { (year): }\end{array}$ & Description of study: & $\begin{array}{l}\text { Data } \\
\text { Class: }\end{array}$ & Conclusions: \\
\hline $\begin{array}{l}\text { Hassler et } \\
\text { al (2014) }\end{array}$ & $\begin{array}{l}\text { Study Description: } \\
\text { Open label single center trial of patients } \\
\text { with progressive GBM treated with } \\
\text { imatinib if patient tumor IHC positive for } \\
\text { PDGF-R, c-abl, c-kit, arg, or c-fms } \\
\text { Patient Population: } \\
24 \text { Adult patients with progressive GBM } \\
\text { within at least three months of initial } \\
\text { treatment end with tissue available for } \\
\text { IHC, IHC had to be positive for one or } \\
\text { more imatinib targets, but any number of } \\
\text { recurrences or prior treatments were } \\
\text { allowed. } \\
\text { Treatment Regimen: } \\
\text { Imatinib was given } 400 \text { mg fixed dose per } \\
\text { day continuous oral dosing until tumor } \\
\text { progression, unacceptable toxicity or } \\
\text { consent withdrawal. }\end{array}$ & III & $\begin{array}{l}\text { Results: } \\
\text { Median OS: } 6 \text { mos } \\
\text { Response to treatment: Two } \\
\text { patients achieved PR, } 10 \\
\text { reached stable disease, } 12 \\
\text { showed progression on first } \\
\text { scan. } \\
\text { Toxicity: } \\
\text { Transient peripheral edema of } \\
\text { legs or eyelids in six patients, } \\
\text { abdominal pain in } 3 \text { patients } \\
\text { (until all started on PPI), } \\
\text { nausea and vertigo each in one } \\
\text { patient, all grade } 2 \text { or lower. No } \\
\text { patients stopped imatinib due } \\
\text { to doxicity and none withdrew } \\
\text { consent. } \\
\text { Authors' Conclusions: } \\
\text { Marginal benefit of imatinib } \\
\text { was shown in progressive } \\
\text { GBM. } \\
\text { Comments and Conclusions: } \\
\text { A single center trial without } \\
\text { controls in a small patient } \\
\text { population warrants Class III } \\
\text { designation. }\end{array}$ \\
\hline
\end{tabular}

Abbreviations: $\mathrm{BEV}=$ bevacizumab, OS = overall survival, $\mathrm{PFS}=$ progression free survival, $\mathrm{PFS} 6=$ six month progression free survival, $R R=$ response rate, $P D=$ progressive disease, $S D=$ stable disease, $C R$ = complete response, $\mathrm{PR}=$ partial response, $\mathrm{AE}=$ adverse event, $\mathrm{TMZ}=$ temozolomide, $\mathrm{GBM}=$ glioblastoma, $\mathrm{RT}$ = radiation therapy, $\mathrm{HTN}$ = hypertension, $\mathrm{CHF}=$ congestive heart failure, VTE = venous thromboembolism, $\mathrm{PE}=$ pulmonary embolism, $\mathrm{ALT}=$ alanine aminotransferase, $\mathrm{AST}=$ aspartate aminotransferace, $\mathrm{GBq}=$ Gigabecquerel, $\mathrm{IHC}=$ immunohistochemistry, PDGF-R = platelet derived growth factor receptor, arg = arginine 


\begin{tabular}{|c|c|c|c|}
\hline $\begin{array}{l}\text { Author } \\
\text { (year): }\end{array}$ & Description of study: & $\begin{array}{l}\text { Data } \\
\text { Class: }\end{array}$ & Conclusions: \\
\hline $\begin{array}{l}\text { Wick et al } \\
\text { (2014) }\end{array}$ & $\begin{array}{l}\text { Study Description: } \\
\text { A Phase II, Randomized, Study of Weekly } \\
\text { APG101 Reirradiation versus } \\
\text { Reirradiation in Progressive } \\
\text { Glioblastoma } \\
\text { Patient Population: } \\
91 \text { adult patients with } 1 \text { st or } 2 \text { nd } \\
\text { recurrence GBM } \\
\text { Treatment Regimen: } \\
\text { Patients were centrally randomized } 1: 2 \text { to } \\
\text { receive rRT ( } 36 \text { Gy) or rRT ( } 36 \text { Gy) } \\
+ \text { APG101 } 400 \text { mg weekly until } \\
\text { progression }\end{array}$ & II & $\begin{array}{l}\text { Results: } \\
\text { rRT PFS6 3.8\%< PFS 2.5m, OS } \\
\text { rRT + APG101: PFS6 20.7\%, } \\
\text { PFS 4.5m } \\
\text { OS } 11.5 \mathrm{~m} \text { for both } \\
\text { Toxicity: } \\
22 \text { patients with severe AE, } \\
\text { none discontinued treatment } \\
\text { Authors' Conclusions: } \\
\text { CD95 pathway inhibition in } \\
\text { combination with rRT is an } \\
\text { innovative concept with clinical } \\
\text { efficacy. It warrants further } \\
\text { clinical development. CD } 95 \mathrm{~L} \\
\text { promoter methylation in the } \\
\text { tumor may be } \\
\text { developed as a biomarker. } \\
\text { Comments and Conclusions: } \\
\text { A Phase Il trial with } \\
\text { randomization in a moderate } \\
\text { patient population warrants } \\
\text { Class II designation. }\end{array}$ \\
\hline
\end{tabular}

Abbreviations: $\mathrm{BEV}=$ bevacizumab, $\mathrm{OS}=$ overall survival, $\mathrm{PFS}=$ progression free survival, $\mathrm{PFS} 6=\mathrm{six}$ month progression free survival, $R R=$ response rate, $P D=$ progressive disease, $S D=$ stable disease, $C R$ = complete response, $\mathrm{PR}=$ partial response, $\mathrm{AE}=$ adverse event, $\mathrm{TMZ}=$ temozolomide, $\mathrm{GBM}=$ glioblastoma, $\mathrm{RT}$ = radiation therapy, $\mathrm{HTN}=$ hypertension, $\mathrm{CHF}=$ congestive heart failure, VTE = venous thromboembolism, $\mathrm{PE}=$ pulmonary embolism, $\mathrm{ALT}=$ alanine aminotransferase, $\mathrm{AST}=$ aspartate aminotransferace, $\mathrm{GBq}=$ Gigabecquerel, $\mathrm{IHC}=$ immunohistochemistry, PDGF-R = platelet derived growth factor receptor, arg = arginine 


\begin{tabular}{|c|c|c|c|}
\hline $\begin{array}{l}\text { Author } \\
\text { (year): }\end{array}$ & Description of study: & $\begin{array}{l}\text { Data } \\
\text { Class: }\end{array}$ & Conclusions: \\
\hline \multirow{12}{*}{$\begin{array}{l}\text { Wuthrick et } \\
\text { al (2014) }\end{array}$} & Study Description: & III & Results: \\
\hline & $\begin{array}{l}\text { Pilot Study of Hypofractionated } \\
\text { Stereotactic Radiation Therapy and } \\
\text { Sunitinib in Previously }\end{array}$ & & $\begin{array}{l}\text { OS GBM Only } 12.7 \mathrm{~m}, \text { PFS } \\
6.4 \mathrm{~m}, \mathrm{PFS} 650 \% \text {, RR - PR/CR } \\
10 \% \text {, SD } 60 \%, \text { PD } 30 \%\end{array}$ \\
\hline & $\begin{array}{l}\text { Irradiated Patients With Progressive High- } \\
\text { Grade }\end{array}$ & & \multirow{6}{*}{$\begin{array}{l}\text { Toxicity: } \\
\text { generalized data, not specific to } \\
\text { GBM: } 5 \text { patients had grade } 1 \\
\text { toxicity including } \\
\text { thrombocytopenia }(n=4) \text {, } \\
\text { leukopenia }(n=3) \text { and } \\
\text { hyponatremia }(n=3) \text {. Five } \\
\text { patients had grade } 2 \text { toxicity } \\
\text { including hematologic } \\
\text { disorders, fatigue, hypertension, } \\
\text { esophagitis and elevated liver } \\
\text { enzymes. One patient had a } \\
\text { grade } 4 \text { oral ulcer. }\end{array}$} \\
\hline & Glioma & & \\
\hline & Patient Population: & & \\
\hline & $\begin{array}{l}11 \text { adult patients with } \mathrm{HGG}, 7 \text { patients } \\
\text { with progressive GBM }\end{array}$ & & \\
\hline & Treatment Regimen: & & \\
\hline & \multirow{5}{*}{$\begin{array}{l}\text { During the treatment period, } 37.5 \mathrm{mg} \\
\text { sunitinib was given starting on RT day } 1 \\
\text { and then daily including weekends. }\end{array}$} & & \\
\hline & & & Authors' Conclusions: \\
\hline & & & $\begin{array}{l}\text { Sunitinib at a daily dose of } \\
37.5 \mathrm{mg} \text { given concurrently } \\
\text { with hypofractionated } \\
\text { stereotactic reirradiation for } \\
\text { rHGG yields acceptable } \\
\text { toxicities and an encouraging } \\
\text { 6-month progression-free } \\
\text { survival. }\end{array}$ \\
\hline & & & Comments and Conclusions: \\
\hline & & & $\begin{array}{l}\text { A phase } 1 \text { study in } 11 \text { patients } \\
\text { without control or } \\
\text { randomization warrants Class } \\
\text { Ill designation. }\end{array}$ \\
\hline
\end{tabular}

Abbreviations: $\mathrm{BEV}=$ bevacizumab, OS = overall survival, $\mathrm{PFS}=$ progression free survival, $\mathrm{PFS} 6=$ six month progression free survival, $\mathrm{RR}=$ response rate, $\mathrm{PD}=$ progressive disease, $\mathrm{SD}=$ stable disease, $\mathrm{CR}$ = complete response, $\mathrm{PR}=$ partial response, $\mathrm{AE}=$ adverse event, $\mathrm{TMZ}=$ temozolomide, $\mathrm{GBM}=$ glioblastoma, $\mathrm{RT}$ = radiation therapy, $\mathrm{HTN}=$ hypertension, $\mathrm{CHF}=$ congestive heart failure, $\mathrm{VTE}=$ venous thromboembolism, $\mathrm{PE}=$ pulmonary embolism, $\mathrm{ALT}=$ alanine aminotransferase, $\mathrm{AST}=$ aspartate aminotransferace, $\mathrm{GBq}=$ Gigabecquerel, $\mathrm{IHC}=$ immunohistochemistry, PDGF-R = platelet derived growth factor receptor, arg = arginine 


\begin{tabular}{|c|c|c|c|}
\hline $\begin{array}{l}\text { Author } \\
\text { (year): }\end{array}$ & Description of study: & $\begin{array}{l}\text { Data } \\
\text { Class: }\end{array}$ & Conclusions: \\
\hline $\begin{array}{l}\text { Muhic et al } \\
\text { (2013) }\end{array}$ & $\begin{array}{l}\text { Study Description: } \\
\text { An open-label, uncontrolled phase II study } \\
\text { of nintedanib in patients with progressive } \\
\text { GBM. } \\
\text { Patient Population: } \\
\text { Adult patients with progressive GBM who } \\
\text { failed either radiotherapy plus TMZ }(n= \\
\text { 13) or had failed radiotherapy and TMZ } \\
\text { as well as second-line BEV }(n=12) \text {. } \\
\text { Treatment Regimen: Nintedanib orally } \\
200 \text { mg twice daily. }\end{array}$ & III & $\begin{array}{l}\text { Results: } \\
\text { Median OS: } 6 \text { mos } \\
\text { Response to treatment: Best } \\
\text { response was stable disease in } \\
\text { three patients. All others } \\
\text { progressed within the first four } \\
\text { 28-day cycles. } \\
\text { Toxicity: } \\
\text { Grade 1-2 fatigue, loss of } \\
\text { appetite, diarrhea and nausea. } \\
\text { Authors' Conclusions: } \\
\text { Single-agent nintedanib } \\
\text { demonstrated limited, but } \\
\text { clinically non-relevant } \\
\text { antitumor activity in patients } \\
\text { with progressive GBM who had } \\
\text { failed 1-2 prior lines of } \\
\text { therapy. } \\
\text { Comments and Conclusions: } \\
\text { A nonrandomized study } \\
\text { without control in a small } \\
\text { cohort warrants Class III } \\
\text { designation. }\end{array}$ \\
\hline
\end{tabular}

Abbreviations: $\mathrm{BEV}=$ bevacizumab, $\mathrm{OS}=$ overall survival, $\mathrm{PFS}=$ progression free survival, $\mathrm{PFS} 6=\mathrm{six}$ month progression free survival, $R R=$ response rate, $P D=$ progressive disease, $S D=$ stable disease, $C R$ = complete response, $\mathrm{PR}=$ partial response, $\mathrm{AE}=$ adverse event, $\mathrm{TMZ}=$ temozolomide, $\mathrm{GBM}=$ glioblastoma, $\mathrm{RT}=$ radiation therapy, $\mathrm{HTN}=$ hypertension, $\mathrm{CHF}=$ congestive heart failure, VTE = venous thromboembolism, $\mathrm{PE}=$ pulmonary embolism, $\mathrm{ALT}=$ alanine aminotransferase, $\mathrm{AST}=$ aspartate aminotransferace, $\mathrm{GBq}=$ Gigabecquerel, $\mathrm{IHC}=$ immunohistochemistry, PDGF-R = platelet derived growth factor receptor, arg = arginine 


\begin{tabular}{|c|c|c|c|}
\hline $\begin{array}{l}\text { Author } \\
\text { (year): }\end{array}$ & Description of study: & $\begin{array}{l}\text { Data } \\
\text { Class: }\end{array}$ & Conclusions: \\
\hline \multirow{10}{*}{$\begin{array}{l}\text { Gilbert et al } \\
\text { (2012) }\end{array}$} & Study Description: & III & Results: \\
\hline & $\begin{array}{l}\text { Prospective phase I trial of post-re- } \\
\text { resection treatment with cilengitide. }\end{array}$ & & $\begin{array}{l}\text { The } 6 \text {-month progression free } \\
\text { survival rate was } 12 \% \text {. }\end{array}$ \\
\hline & Patient Population: & & Toxicity: \\
\hline & & & \multirow{3}{*}{$\begin{array}{l}\text { There were } 9 \text { grade } 3-4 \\
\text { toxicities, mainly lymphopenia, } \\
\text { likely related to prior cytotoxic } \\
\text { chemotherapy. There were no } \\
\text { dose reductions for toxicity and } \\
\text { no treatment related deaths. }\end{array}$} \\
\hline & Treatment Regimen: & & \\
\hline & Cilengitide 2000 mg i.v. twice weekly & & \\
\hline & & & Authors' Conclusions: \\
\hline & & & $\begin{array}{l}\text { This study provides evidence } \\
\text { that with established dosing, } \\
\text { cilengitide is adequately } \\
\text { delivered to the tumor, although } \\
\text { as a signle agent, efficacy in } \\
\text { progressive GBM is modest. }\end{array}$ \\
\hline & & & Comments and Conclusions: \\
\hline & & & $\begin{array}{l}\text { A prospective phase } 1 \text { trial in a } \\
\text { small patient cohort without a } \\
\text { control warrants class III } \\
\text { designation. }\end{array}$ \\
\hline
\end{tabular}

Abbreviations: $\mathrm{BEV}=$ bevacizumab, $\mathrm{OS}=$ overall survival, $\mathrm{PFS}=$ progression free survival, $\mathrm{PFS} 6=\mathrm{six}$ month progression free survival, $R R=$ response rate, $P D=$ progressive disease, $S D=$ stable disease, $C R$ = complete response, $\mathrm{PR}=$ partial response, $\mathrm{AE}=$ adverse event, $\mathrm{TMZ}=$ temozolomide, $\mathrm{GBM}=$ glioblastoma, $\mathrm{RT}$ = radiation therapy, $\mathrm{HTN}=$ hypertension, $\mathrm{CHF}=$ congestive heart failure, $\mathrm{VTE}=$ venous thromboembolism, $\mathrm{PE}=$ pulmonary embolism, $\mathrm{ALT}=$ alanine aminotransferase, $\mathrm{AST}=$ aspartate aminotransferace, $\mathrm{GBq}=$ Gigabecquerel, $\mathrm{IHC}=$ immunohistochemistry, PDGF-R = platelet derived growth factor receptor, arg = arginine 


\begin{tabular}{|c|c|c|c|}
\hline $\begin{array}{l}\text { Author } \\
\text { (year): }\end{array}$ & Description of study: & $\begin{array}{l}\text { Data } \\
\text { Class: }\end{array}$ & Conclusions: \\
\hline Pan (2012) & $\begin{array}{l}\text { Study Description: } \\
\text { A prospective phase II single-institution } \\
\text { trial of sunitinib for } \\
\text { progressive malignant glioma } \\
\text { Patient Population: } \\
16 \text { adult patients with progressive GBM } \\
\text { Treatment Regimen: } \\
\text { Trial patients received } \\
\text { sunitinib } 50 \text { mg daily for } 4 \text { weeks without } \\
\text { regard to meals, followed by a } 2 \text {-week } \\
\text { rest period. This } 6 \text {-week regimen } \\
\text { constituted } 1 \text { cycle. Patients were treated } \\
\text { for up to } 9 \text { cycles }(\sim 1 \text { year) or until } \\
\text { disease progression or death or if } \\
\text { persistent toxicities occurred. }\end{array}$ & III & $\begin{array}{l}\text { Results: } \\
\text { PFS6: } 12.5 \% \text {, PFS } 1.4 \mathrm{~m}, \text { OS } \\
12.6 \mathrm{~m} \\
\text { Response Rate: Stable Disease } \\
\text { or better: } 31.3 \% \\
\text { Toxicity: } \\
4 \text { patients had Grade } 3,1 \text { grade } \\
4 \\
\text { neutropenia/thrombocytopenia, } \\
56.3 \% \text { had fatigue, } 43.8 \% \\
\text { diarrhea, } 31.3 \% \text { neutropenia, } \\
25 \% \text { thrombocytopenia. } \\
\text { Authors' Conclusions: } \\
\text { Although sunitinib was deemed } \\
\text { to be a potentially effective } \\
\text { treatment for progressive MAG, } \\
\text { the current study is concordant } \\
\text { with prior studies confirming } \\
\text { lack of significant anti-glioma } \\
\text { activity. This may be due to the } \\
\text { possibility that the tolerated } \\
\text { dose of sunitinib may be } \\
\text { insufficient to significantly } \\
\text { affect tumor growth or induce } \\
\text { tumor responses. } \\
\text { Comments and Conclusions: } \\
\text { A small nonrandomized trial } \\
\text { without control warrants Class } \\
\text { Ill designation. }\end{array}$ \\
\hline $\begin{array}{l}\text { Abbreviation } \\
\text { month progr } \\
=\text { complete } r \\
\text { glioblastom } \\
\text { venous thro } \\
\text { aspartate an } \\
\text { derived gron }\end{array}$ & $\begin{array}{l}\mathrm{BEV}=\text { bevacizumab, } \mathrm{OS}=\text { overall survival, } \mathrm{P} \\
\text { sion free survival, } \mathrm{RR}=\text { response rate, } \mathrm{PD}= \\
\text { onse, } \mathrm{PR}=\text { partial response, } \mathrm{AE}=\text { adverse } \\
\mathrm{RT}=\text { radiation therapy, } \mathrm{HTN}=\text { hypertension, } \\
\text { oembolism, } \mathrm{PE}=\text { pulmonary embolism, } \mathrm{ALT} \\
\text { otransferace, } \mathrm{GBq}=\text { Gigabecquerel, } \mathrm{IHC}=\text { in } \\
\text { factor receptor, arg = arginine }\end{array}$ & $\begin{array}{l}S=\text { progi } \\
\text { ogressive } \\
\text { ent, TMZ } \\
\text { HF = con } \\
\text { =alanine } \\
\text { munohist }\end{array}$ & $\begin{array}{l}\text { ession free survival, PFS6 = six } \\
\text { disease, } \mathrm{SD}=\text { stable disease, } \mathrm{CR} \\
\text { = temozolomide, GBM = } \\
\text { estive heart failure, VTE = } \\
\text { aminotransferase, AST = } \\
\text { chemistry, PDGF-R = platelet }\end{array}$ \\
\hline
\end{tabular}

A total of 23 articles described the use of targeted therapies alone, not including BEV.[49-66;68; 69; 72] Two studies used a targeted therapy in conjunction with repeat radiation therapy.[49; 50] One study discussed the use of a cytotoxic agent (temsirolimus) in conjunction with Sorafenib.[72] Another study involved intracavity delivery of a targeted agent.[59] Retinoic acid naphthalene was given in another study, which was the only update discovered on the use of retinoids in progressive glioblastoma.[61] Combination of targeted agents (cediranib and cilengitide) were given in one study while cediranib and 
gefitinib were administered in combination in another study, providing the only two studies using combinations of targeted therapies.[63; 67] The remainder of studies were single agent targeted therapies.[51-58; 60; 62; 64-69]

\section{Single Agent Targeted Therapies}

Targeted therapies have been gaining attention recently, especially with the identification and characterization of several molecular variations among glioblastoma and the possibility of temozolomide resistance. Furthermore, there is a renewed vigor to find an effective, individualized molecular treatment for glioblastoma, especially in the progressive setting, beyond BEV.

Several small molecule targeted therapies were evaluated. Pitz et al evaluated the use of PX-866 in 33 adult patients with progressive glioblastoma.[52] The study found a PFS6 of $17 \%$. The authors concluded that although the drug was well tolerated, it did not meet the predetermined efficacy end points. Aiken et al provided a phase I clinical trial with dose escalation of a small molecule inhibitor of IGF1b in a small group of 7 patients.[69] They concluded there was a sustained clinical response. As it was a doseescalation trial and had no control group, it was given a designation of Class III evidence. PLX3397, a Colony Stimulating Factor 1 Receptor inhibitor was given to 13 patients, finding a mOS of 9.5 months with no radiographic responses.[66] This was also designated Class III as it was a small cohort without randomization.. Gilbert et al studied cilengitide along with resection after recurrence in 26 patients and established the efficacy was only modest, yielding a Class III designation as a small Phase I trial in a small number of patients.[71]

Depatux-m was studied by Gan et al as a multicenter, Phase I dose escalation study which combined newly diagnosed and progressive glioblastoma.[64] In the data separable for progressive patients, median OS was 10.7 months with $30.8 \%$ of patients reaching PFS6. Results were considered encouraging, the study was small without a control. Lassman et al also studied administration of depatux-m in 60 patients with EGFR amplification in progressive glioblastoma without prior BEV or nitrosourea administration.[57] Median OS was 7.4 months and median PFS 2.1 months, with authors concluding the TMZ refractory population showed encouraging results. Van Den Bent et al studied the efficacy of depatux-m in 66 patients.[70] All patients had EGFR amplified glioblastoma, and results showed a PFS6 of $28.7 \%$, PFS 1.7 months, mOS 9.3 months. The authors concluded that monotherapy in these patients showed some efficacy and tolerable toxicity requiring further study. These three trials lacked control groups and were nonrandomized, designating each as Class III evidence.

\section{Tyrosine Kinase Inhibitors}

Several studies also focused on tyrosine kinase inhibitors. Gallego et al evaluated erlotinib in 13 progressive glioblastoma patients harboring PTEN, EGFR, and EGFRvIll overexpression.[65] PFS6 was $20 \%$. Authors felt this was of no benefit and that it was not cost-effective in this patient population. Tivozanib was evaluated in a phase II study of 10 patients by Kalpathy-Cramer et al and showed a mOS of 8.1 months but discovered limited anti-tumor activity.[60] Lassman et al evaluated 50 patients with 
BEV naïve recurrence, overexpression of SRC, PDGFR, EPHA2, and/or c-kit and administration of dasatinib monotherapy, also without any benefit.[58]

Several of the included studies revolved around Tyrosine Kinase inhibitors with a focus on PDGFR interaction. Muhic et al evaluated the use of nintedanib in 25 progressive glioblastoma patients with similar findings of a lack of anti-tumor activity.[55] Phuphanich reviewed the utility of targeting PDGFRalpha with MEDI-575 in a Phase II, multi center, open-label study in 51 progressive glioblastoma patients.[53] PFS6 was $15.4 \%$ and mOS 9.7 months, but also showed limited activity in comparison to historical controls at first recurrence. Batchelor et al completed Phase I and II trials of the PDGFRa inhibitor tandutinib in 19 patients and 30 patients, respectively.[68] Median OS was 8.8 months and PFS6 was $16 \%$ and the study was closed early due to a lack of efficacy. Hassler et al studied the utilization of imatinib in 24 patients with PDGF-R, c-abl, c-kit, arg, or c-fms detected.[62] In a group that combined patients at varying numbers of recurrences, mOS was 6 months and only marginal benefit was seen.

Pan et al attempted sunitinib administration in a phase II single institution trial of 16 patients.[54] $12.5 \%$ of patients reached PFS6, PFS was 1.4 months, and mOS was 12.6 months. $31.3 \%$ of patients had stable disease or better. The authors concluded sunitinib could be a potentially effective treatment for progressive glioblastoma, although this and prior studies showed a lack of significant anti-glioma activity. This was designated Class III for a small, nonrandomized trial design without a control group.

Regorafenib, an oral receptor tyrosine kinase inhibitor targeting VEGFR-2, was compared with lomustine in a moderately sized, multi-center, randomized trial which showed an encouraging survival benefit with the use of regorafenib.[56] In about 119 patients trialed with progressive glioblastoma, the group given regorafenib saw mOS of 7.4 months compared to 5.6 months in the lomustine group. This study design warranted Class II designation.

\section{Retinoids}

Prior studies showed minimal to no activity of retinoids alone at recurrence, with a single example of a retinoid combined with $T M Z$ showing a survival benefit compared to $T M Z$ alone, but with only minimal radiographic response rates.[73] In our update, a study by Jia et al was a prospective nonrandomized trial with administration of retinoic acid naphthalene in 19 patients.[61] Median OS was 69 weeks (16.1 months), Median PFS was 28 weeks and the authors concluded retinoic acid naphthalene triazole may have a role in treatment of progressive glioblastoma with $45 \%$ of patients reaching PFS6.

\section{Stereotactic Intratumoral Delivery}

Krolicki et al evaluated the efficacy of placement of a subcutaneous port with catheters stereotactically driven into the tumor cavity for future administration of 213Bi-DOTA-substance $P$ in a single arm prospective study.[59] Median OS was 10.9 months, 55\% of patients remained alive at 6 months, $40 \%$ at 12 months, and $30 \%$ were surviving at 18 months of follow up from the start of treatment. The authors concluded the mOS of 10.9 months compared favorably to standard treatments. This was also designated Class III as the study was a small sample size without a control group. 


\section{Buparlisib (PI3K inhibition)}

Wen et al used buparlisib to target phosphatidylinositol-3-kinase in 65 patients with progressive glioblastoma at their first or second relapse.[51] Results showed PFS6 of $67 \%$ in cohort 1, 8\% in cohort 2. PFS was 1.8 months in Cohort 1 and 1.7 months in cohort 2 with OS of 17.9 versus 9.8 months, respectively. The authors concluded the PI3K inhibitor, known to penetrate the blood brain barrier, had efficacy as a single agent but did not meet pharmacodynamic and efficacy end points and the findings were consistent with prior studies showing no clinical benefit in patients unselected for PI3K pathway activation. This was designated Class III as the trial lacked randomization and there was no control group.

\section{Dual Agent Targeted Therapy}

We encountered two studies using a combination of targeted therapies. [63; 67] One, a study by Gerstner et al, gave cilengitide, an anti-angiogenic small molecule targeting integrins, and cediranib, an oral VEGF inhibitor, in a phase I trial, warranting class III designation.[63] Forty patients were treated and results showed a mOS of 6.5 months and response rates at $8.9 \%$, with a conclusion that although the regimen was well tolerated, there was no overall benefit discerned to warrant further study. Brown et al compared cediranib and gefitinib to cediranib and placebo with 19 patients in each group.[67] Response rates were $42 \% \mathrm{PR}$ in the combination group and $26 \%$ in the placebo arm and mOS of 7.2 months in the combination group and 5.5 months in placebo arm. PFS was 3.6 months in the combination therapy group and 2.8 months in the placebo group. The study suffered from incomplete recruitment due to discontinuation of cediranib production mid-study, but concluded there was a trend toward improved survival and response rates. This was designated Class II data as it was a multicenter, double-blind, randomized, control trial with a small sample size.

\section{Radiation and Targeted Therapies}

We found two studies regarding targeted therapies specifically and intentionally used in combination with repeat radiation therapy.[49; 50] Wuthrick et al completed a pilot study of hypofractionated stereotactic radiation therapy in conjunction with sunitinib.[49] Eleven patients were studied, 7 of which were progressive glioblastoma previously treated with radiotherapy. Results specifically for progressive glioblastoma patients included an OS of 12.7 months, PFS of 6.4 months, PFS 6 of $50 \%$, and response rates including $10 \% \mathrm{PR} / \mathrm{CR}, 60 \%$ with SD and $30 \%$ with $\mathrm{PD}$. The authors concluded the results were encouraging in terms of PFS6 and safety and warrant further study. This was designated Class III for a small, nonrandomized cohort without a control group.

Wick et al studied the effect of APG101 (CD95/CD95L inhibitor) with reirradiation (rRT) versus only reirradiation.[50] 91 patients at the first or second recurrence were randomized and the irradiation only group had a PFS6 of $3.8 \%$ and PFS 2.5 months, while the combination treatment group had a PFS6 of $20.7 \%$ and PFS 4.5 months. They concluded CD95 pathway inhibition with rRT had clinical efficacy and 
needed further study and potentially more identification of patients with CD95L promoter methylation as a biomarker. This was designated Class II evidence with a moderate size population and randomization.

\section{Synthesis:}

The prior guidelines on targeted therapy included studies on a wide array of targeted therapies. The only new studies providing encouraging results but without significant discernible benefit were the studies regarding Depatux-m, showing mOS of 7.4 to 10.7 months in early phase trials, and radiation with targeted therapies with one Class II study showing a significant benefit compared to RT alone at recurrence. Another promising Class II study showed only a trend toward a survival benefit when combining Gefitinib and cediranib, improving slightly upon the data in the prior guidelines showing a gefitinib with at most a potential efficacy in monotherapy. Regorafenib, another set of class II data, saw a survival benefit compared to cytotoxic treatment. The rest of the evidence was Class III evidence with significant limitations in trial and study designs, with no new data showing improved clinical benefit with tyrosine kinase inhibitors, buparlisib, or retinoids. Thus, there was no significant evidence to provide a clear

recommendation at this time. This conclusion is not meant to suggest that studies of targeted agents alone or in combination are not worthy of further investigation and it is suggested that when available, and patients meet inclusion criteria, they be enrolled in properly designed studies that address these modalities.

Question 5: In adults with progressive glioblastoma is the use of targeted agents in combination with cytotoxic therapies superior to standard salvage cytotoxic chemotherapy as measured by progression free survival and overall survival?

Prior Recommendations: In the previously published guidelines on the role of targeted therapies in management of progressive glioblastoma in adults, targeted therapies other than bevacizumab in combination with cytotoxic therapies were reviewed and no specific recommendations were made based on a lack of strong evidence supporting a clearly defined benefit or detriment.

\section{Recommendation}

There is insufficient evidence to support a recommendation regarding this question.

\section{Study selection and characteristics of the updated search:}

The initial search strategy included 3513 candidate articles. A total of 65 articles remained for full text review. From these, 8 articles were included in the final review for question 5 and are included in Table 5 below.[74-81] 
Table 5

The role of targeted therapies combined with cytotoxic therapies in progressive GBM.

\begin{tabular}{|c|c|c|c|}
\hline $\begin{array}{l}\text { Author } \\
\text { (year): }\end{array}$ & Description of study: & $\begin{array}{l}\text { Data } \\
\text { Class: }\end{array}$ & Conclusions: \\
\hline $\begin{array}{l}\text { Grisanti et } \\
\text { al (2019) }\end{array}$ & $\begin{array}{l}\text { Study Description: } \\
\text { single-center, prospective, open- } \\
\text { label, non-ran- domized phase } 2 \\
\text { trial evaluating activity of } \\
\text { sunitinib plus CPT-11 in } \\
\text { progressive GBM } \\
\text { Patient Population: } \\
6 \text { Adult patients with first relapse } \\
\text { of GBM or progression after } \\
\text { surgical resection and } \\
\text { radiotherapy plus concomitant } \\
\text { and adjuvant TMZ } \\
\text { Treatment Regimen: } \\
\text { CPT-11 was administered at } 125 \\
\text { mg/sqm over } 90 \text { min IV infusion } \\
\text { repeated every } 14 \text { days on } 28 \text { day } \\
\text { cycle. Sunitinib was given at a } \\
\text { dose of } 37.5 \text { mg orally once a day } \\
\text { for } 14 \text { days followed by } 14 \text { day } \\
\text { sunitinib rescue on each } 28 \text { day } \\
\text { cycle. Cycle was repeated until } \\
\text { disease progression or } \\
\text { unacceptable toxicity. }\end{array}$ & III & $\begin{array}{l}\text { Results: } \\
\text { Median OS: not reported since trial } \\
\text { aborted early due to lack of efficacy. } \\
\text { Response to treatment: Among the first } \\
\text { six patients enrolled in the Stage I of } \\
\text { the trial, only one had stable disease } \\
\text { with a response rate of } 17 \% \text {. Trial was } \\
\text { aborted early and 6-PFS was not } \\
\text { reached. } \\
\text { Toxicity: } \\
\text { All toxicities were grade 1-2. All } \\
\text { patients required steroid therapy and } \\
5 / 6 \text { required acetazolamide for } \\
\text { symptomatic cerebral edema and } \\
\text { prophylactic levetiracetam as anti- } \\
\text { epileptic prophylaxis. Skin atrophy and } \\
\text { decoloration was most common, with } \\
\text { fatigue, nausea and leukopenia also } \\
\text { common. } \\
\text { Authors' Conclusions: } \\
\text { The combination of carboplatin and } \\
\text { bevacizumab is active and well- } \\
\text { tolerated in progressive HGG } \\
\text { Comments and Conclusions: } \\
\text { A small, nonrandomized series } \\
\text { warrants Class III designation. }\end{array}$ \\
\hline
\end{tabular}

Abbreviations: $\mathrm{BEV}$ = bevacizumab, OS = overall survival, $\mathrm{PFS}=$ progression free survival, $\mathrm{PFS} 6$ = six month progression free survival, $\mathrm{RR}=$ response rate, $\mathrm{PD}=$ progressive disease, $\mathrm{SD}=$ stable disease, $\mathrm{CR}$ = complete response, $\mathrm{PR}=$ partial response, $\mathrm{AE}=$ adverse event, $\mathrm{TMZ}=$ temozolomide, $\mathrm{GBM}=$ glioblastoma, $\mathrm{RT}=$ radiation therapy, $\mathrm{HTN}$ = hypertension, $\mathrm{CHF}=$ congestive heart failure, $\mathrm{VTE}=$ venous thromboembolism, $\mathrm{PE}=$ pulmonary embolism, $\mathrm{ALT}$ = alanine aminotransferase, $\mathrm{AST}=$ aspartate aminotransferace, 


\begin{tabular}{|c|c|c|c|}
\hline $\begin{array}{l}\text { Author } \\
\text { (year): }\end{array}$ & Description of study: & $\begin{array}{l}\text { Data } \\
\text { Class: }\end{array}$ & Conclusions: \\
\hline $\begin{array}{l}\text { Di } \\
\text { Cristofori } \\
\text { et al (2017) }\end{array}$ & $\begin{array}{l}\text { Study Description: } \\
\text { TMZ + Tamoxifen in progressive } \\
\text { glioblastoma } \\
\text { Patient Population: } \\
32 \text { adult patients with progressive } \\
\text { GBM after standard first line } \\
\text { therapy } \\
\text { Treatment Regimen: } \\
\text { The treatment at tumor relapse } \\
\text { consisted of TMZ dose-dense at } \\
75-150 \mathrm{mg} / \mathrm{m} 2 \text { one week on/one } \\
\text { week off plus daily tamoxifen at } \\
80 \mathrm{mg} / \mathrm{m}^{\wedge} 2 \text {. }\end{array}$ & III & $\begin{array}{l}\text { Results: } \\
\text { RR: No response in } 18 \text { patients }(56.2 \%) \text {, } \\
\text { PR or Stable in } 13(40.6 \%) \text {, CR in } 1 \\
\text { (3.1\%) } \\
\text { median OS: } 17.5 \mathrm{~m} \text {, methylated MGMT } \\
-20.5 \mathrm{~m} \text {, unmethylated } 15 \mathrm{~m} \\
\text { median TTP 9.5m, MGMT methylated } \\
\text { 11m, unmethylated } 7.5 \mathrm{~m} \\
\text { TTP2 (after tamoxifen + TMZ) 7m } \\
\text { Toxicity: } \\
\text { No toxicity was observed in the } 32 \\
\text { patients } \\
\text { Authors' Conclusions: } \\
\text { Our experience in second-line treatment } \\
\text { of progressive GBM with dose-dense } \\
\text { TMZ plus tamoxifen confirmed that } \\
\text { oral high-dose administration of } \\
\text { tamoxifen was well-tolerated and easily } \\
\text { used. Moreover, this study confirms the } \\
\text { hypothesis that oral high-dose } \\
\text { tamoxifen associated with dose-dense } \\
\text { TMZ can increase OS and TTP in } \\
\text { patients with progressive GBM. } \\
\text { Patients with unmethylated MGMT } \\
\text { might benefit } \\
\text { more from this combined regimen. } \\
\text { Comments and Conclusions: } \\
\text { A small study without a control group } \\
\text { warrants Class III designation. }\end{array}$ \\
\hline
\end{tabular}

Abbreviations: $\mathrm{BEV}=$ bevacizumab, OS = overall survival, $\mathrm{PFS}=$ progression free survival, $\mathrm{PFS} 6=$ six month progression free survival, $R R=$ response rate, $P D=$ progressive disease, $S D=$ stable disease, $C R$ = complete response, $\mathrm{PR}=$ partial response, $\mathrm{AE}=$ adverse event, $\mathrm{TMZ}=$ temozolomide, $\mathrm{GBM}=$ glioblastoma, $\mathrm{RT}=$ radiation therapy, $\mathrm{HTN}$ = hypertension, $\mathrm{CHF}=$ congestive heart failure, $\mathrm{VTE}=$ venous thromboembolism, $\mathrm{PE}=$ pulmonary embolism, $\mathrm{ALT}$ = alanine aminotransferase, $\mathrm{AST}=$ aspartate aminotransferace, 


\begin{tabular}{|c|c|c|c|}
\hline $\begin{array}{l}\text { Author } \\
\text { (year): }\end{array}$ & Description of study: & $\begin{array}{l}\text { Data } \\
\text { Class: }\end{array}$ & Conclusions: \\
\hline $\begin{array}{l}\text { Duerinck et } \\
\text { al (2017) }\end{array}$ & $\begin{array}{l}\text { Study Description: } \\
\text { Randomized phase } 2 \text { trial of } \\
\text { axitinib monotherapy vs axitinib } \\
\text { and lomustine in progressive } \\
\text { GBM } \\
\text { Patient Population: } \\
79 \text { patients were randomized to } \\
\text { axitinib monotherapy }(n=50) \text { or } \\
\text { axitinib + lomustine }(n=29) \text { with } \\
\text { crossover to the combination arm } \\
\text { allowed at disease progression (n } \\
=19) \text {. } \\
\text { Treatment Regimen: } \\
\text { Axitinib } 5 \text { mg twice daily } \\
\text { increased as tolerated to } 7 \text { or } 10 \\
\text { mg BID, or dose reduced to } 3 \text { or } 2 \\
\text { mg BID for toxicity. Axitinib same } \\
\text { dosing in combination with } \\
\text { lomustine. Lomustine } 90 \mathrm{mg} / \mathrm{m}^{\wedge} 2 \\
\text { every } 6 \text { weeks. }\end{array}$ & III & $\begin{array}{l}\text { Results: } \\
\text { Median OS: } 29 \text { weeks in axitinib } \\
\text { monotherapy and } 27.4 \text { weeks in } \\
\text { combination with lomustine } \\
\text { Response to treatment: Best overall } \\
\text { response rate was } 28 \% \text { for axinitib } \\
\text { monotherapy and } 38 \% \text { for combination, } \\
\text { with disease control rates of } 52 \text { and } \\
45 \% \text {, respectively. } \\
\text { Toxicity: } \\
\text { Axitinib monotherapy had } 36 \% \text { develop } \\
\text { grade } 3 \text { or higher toxicity, } 39 \% \text { with } \\
\text { combination and included } \\
\text { thrombocytopenia, HTN, neutropenia } \\
\text { (only lomustine arm), lymphopenia, } \\
\text { and anorexia. } \\
\text { Authors' Conclusions: } \\
\text { The authors conclude that axitinib } \\
\text { improves response rate and PFS in } \\
\text { patients with progressive GBM in } \\
\text { comparison to historical controls. } \\
\text { There is no indication that combination } \\
\text { of axitinib with lomustine improves } \\
\text { results. } \\
\text { Comments and Conclusions: } \\
\text { A randomized control trial with a } \\
\text { modest number of patients, but with } \\
\text { significant crossover, warrants Class III } \\
\text { designation. }\end{array}$ \\
\hline
\end{tabular}

Abbreviations: $\mathrm{BEV}=$ bevacizumab, OS = overall survival, $\mathrm{PFS}=$ progression free survival, $\mathrm{PFS} 6=$ six month progression free survival, $\mathrm{RR}=$ response rate, $\mathrm{PD}=$ progressive disease, $\mathrm{SD}=$ stable disease, $\mathrm{CR}$ = complete response, $\mathrm{PR}=$ partial response, $\mathrm{AE}=$ adverse event, $\mathrm{TMZ}=$ temozolomide, $\mathrm{GBM}=$ glioblastoma, $\mathrm{RT}=$ radiation therapy, $\mathrm{HTN}$ = hypertension, $\mathrm{CHF}=$ congestive heart failure, $\mathrm{VTE}=$ venous thromboembolism, $\mathrm{PE}=$ pulmonary embolism, $\mathrm{ALT}$ = alanine aminotransferase, $\mathrm{AST}=$ aspartate aminotransferace, 


\begin{tabular}{|c|c|c|c|}
\hline $\begin{array}{l}\text { Author } \\
\text { (year): }\end{array}$ & Description of study: & $\begin{array}{l}\text { Data } \\
\text { Class: }\end{array}$ & Conclusions: \\
\hline \multirow{10}{*}{$\begin{array}{l}\text { Wang et al } \\
(2017)\end{array}$} & Study Description: & III & Results: \\
\hline & \multirow{2}{*}{\multicolumn{2}{|c|}{$\begin{array}{l}\text { Pilot study of apatinib plus } \\
\text { irinotecan in high-grade glioma }\end{array}$}} & Median OS: $12.8 \mathrm{mos}$ \\
\hline & \multirow{2}{*}{\multicolumn{2}{|c|}{ Patient Population: }} & Response to treatment: PR in 2 \\
\hline & & & $\begin{array}{l}\text { patients, SD in } 2 \text {, PD in } 1 \text { and } 1 \text { not } \\
\text { assessed }\end{array}$ \\
\hline & \multicolumn{2}{|l|}{$\begin{array}{l}10 \text { adult patients with progressive } \\
\text { high-grade glioma ( } 6 \text { with GBM) }\end{array}$} & Toxicity: \\
\hline & \multirow{5}{*}{$\begin{array}{l}\text { Treatment Regimen: Irinotecan } \\
125 \mathrm{mg} / \mathrm{m}^{\wedge} 2 \text { or } 340 \mathrm{mg} / \mathrm{m}^{\wedge} 2 \\
\text { depending on use of enzyme- } \\
\text { inducing antiepileptic druges } \\
\text { every } 21 \text {-day cycle concurrently } \\
\text { with oral apatinib } 500 \mathrm{mg} \text { daily } \\
\text { for first } 6 \text { cycles (dose dropped to } \\
250 \mathrm{mg} \text { if grade } 3 \text { or } 4 \text { toxicity). }\end{array}$} & & $\begin{array}{l}\text { Grade } 3 \text { or higher myelosuppression } \\
\text { (1), GI (2), HTN (1) hand-foot syndrome } \\
\text { (2) for all } 10 \text { patients. }\end{array}$ \\
\hline & & & Authors' Conclusions: \\
\hline & & & $\begin{array}{l}\text { Apatinib combined with irinotecan } \\
\text { seems to be a promising therapeutic } \\
\text { option for progressive malignant } \\
\text { glioma patients. }\end{array}$ \\
\hline & & & Comments and Conclusions: \\
\hline & & & $\begin{array}{l}\text { A small patient cohort without } \\
\text { randomization or control warrants } \\
\text { Class III designation. }\end{array}$ \\
\hline
\end{tabular}

Abbreviations: $\mathrm{BEV}=$ bevacizumab, OS = overall survival, $\mathrm{PFS}=$ progression free survival, $\mathrm{PFS} 6=$ six month progression free survival, $R R=$ response rate, $P D=$ progressive disease, $S D=$ stable disease, $C R$ = complete response, $\mathrm{PR}=$ partial response, $\mathrm{AE}=$ adverse event, $\mathrm{TMZ}=$ temozolomide, $\mathrm{GBM}=$ glioblastoma, $\mathrm{RT}=$ radiation therapy, $\mathrm{HTN}$ = hypertension, $\mathrm{CHF}=$ congestive heart failure, $\mathrm{VTE}=$ venous thromboembolism, $\mathrm{PE}=$ pulmonary embolism, $\mathrm{ALT}$ = alanine aminotransferase, $\mathrm{AST}=$ aspartate aminotransferace, 


\begin{tabular}{|c|c|c|c|}
\hline $\begin{array}{l}\text { Author } \\
\text { (year): }\end{array}$ & Description of study: & $\begin{array}{l}\text { Data } \\
\text { Class: }\end{array}$ & Conclusions: \\
\hline \multirow{10}{*}{$\begin{array}{l}\text { Brandes et } \\
\text { al (2016) }\end{array}$} & Study Description: & II & Results: \\
\hline & $\begin{array}{l}\text { A phase } 2 \text { randomized study of } \\
\text { galunisertib monotherapy vs } \\
\text { galunisertib plus lomustine vs } \\
\text { lomustine monotherapy in }\end{array}$ & & $\begin{array}{l}\text { Median OS: galunisertib + lomustine } \\
\text { was } 6.7 \text { mos, } 8.0 \text { mos for galunisertib } \\
\text { alone and } 7.5 \text { mos for lomustine+ } \\
\text { placebo }\end{array}$ \\
\hline & Patient Population: & & \multirow{2}{*}{$\begin{array}{l}\text { Response to treatment: One patient had } \\
\text { CR in galunisertib + lomustine (1.3\%), } \\
\text { and } 2 \text { patients had PR in the } \\
\text { galunisertib monotherapy arm ( } 5.1 \%) \text {. } \\
\text { Clinical responses occurred in } 21.5 \% \text { of } \\
\text { combination, } 30.8 \% \text { in galunisertib } \\
\text { monotherapy and } 30.0 \% \text { of lomustine } \\
+ \text { placebo. }\end{array}$} \\
\hline & $\begin{array}{l}158 \text { patients with progressive } \\
\text { GBM randomized to galunisertib } \\
(n=39) \text {, lomustine }+ \text { placebo }(n= \\
40) \text { or lomustine plus galunisertib } \\
(n=79) \text {. }\end{array}$ & & \\
\hline & \multirow{6}{*}{$\begin{array}{l}\text { Treatment Regimen: galunisertib } \\
\text { ( } 300 \mathrm{mg} / \mathrm{day} \text { ) orally } 14 \text { days } \\
\text { on/ } 14 \text { days off, lomustine at } \\
\text { standard dosing ( } 100 \mathrm{mg} / \mathrm{m}^{\wedge} 2 \\
\text { after } 7 \text { days of galunisertib } \\
\text { followed by } 100-130 \mathrm{mg} / \mathrm{m}^{\wedge} 2 \\
\text { orally once every } 6 \text { weeks) }\end{array}$} & & Toxicity: \\
\hline & & & $\begin{array}{l}91.1 \% \text { of patients had an adverse } \\
\text { event. Drug-related Grade } 3 / 4 \text { events } \\
\text { occurred in } 10 \% \text { of galunisertib alone } \\
\text { arm, } 26 \% \text { of galunisertib + lomustine } \\
\text { and } 26 \% \text { for lomustine + placebo. }\end{array}$ \\
\hline & & & Authors' Conclusions: \\
\hline & & & $\begin{array}{l}\text { Galunisertib + lomustine failed to } \\
\text { demonstrate improved OS relative to } \\
\text { placebo + lomustine. }\end{array}$ \\
\hline & & & Comments and Conclusions: \\
\hline & & & $\begin{array}{l}\text { A randomized controlled trial with a } \\
\text { modest number of patients warrants } \\
\text { Class II designation. }\end{array}$ \\
\hline
\end{tabular}

Abbreviations: $\mathrm{BEV}=$ bevacizumab, OS = overall survival, $\mathrm{PFS}=$ progression free survival, $\mathrm{PFS} 6=$ six month progression free survival, $R R=$ response rate, $P D=$ progressive disease, $S D=$ stable disease, $C R$ = complete response, $\mathrm{PR}=$ partial response, $\mathrm{AE}=$ adverse event, $\mathrm{TMZ}=$ temozolomide, $\mathrm{GBM}=$ glioblastoma, $\mathrm{RT}=$ radiation therapy, $\mathrm{HTN}$ = hypertension, $\mathrm{CHF}=$ congestive heart failure, $\mathrm{VTE}=$ venous thromboembolism, $\mathrm{PE}=$ pulmonary embolism, $\mathrm{ALT}$ = alanine aminotransferase, $\mathrm{AST}=$ aspartate aminotransferace, 


\begin{tabular}{|c|c|c|c|}
\hline $\begin{array}{l}\text { Author } \\
\text { (year): }\end{array}$ & Description of study: & $\begin{array}{l}\text { Data } \\
\text { Class: }\end{array}$ & Conclusions: \\
\hline \multirow{15}{*}{$\begin{array}{l}\text { Blumenthal } \\
\text { et al (2015) }\end{array}$} & \multirow{4}{*}{$\begin{array}{l}\text { Study Description: } \\
\text { phase III study of radiation } \\
\text { therapy (RT) and O6- } \\
\text { benzylguanine, (O6-BG) plus } \\
\text { BCNU versus RT and BCNU alone } \\
\text { and methylation status in newly- } \\
\text { diagnosed glioblastoma (GBM) } \\
\text { and gliosarcoma. }\end{array}$} & \multirow[t]{15}{*}{ II } & Results: \\
\hline & & & PFS-6 with O6BG: $4 \mathrm{~m}$, without: $4 \mathrm{~m}$ \\
\hline & & & OS with $06: 11 \mathrm{~m}$, without: $10 \mathrm{~m}$ \\
\hline & & & $\begin{array}{l}\text { Methylated patients: } 13 \mathrm{~m} \text { OS, PFS- } 6 \\
4 \mathrm{~m} \text {. Unmethylated OS } 11 \mathrm{~m}, \text { PFS6 } 3 \mathrm{~m}\end{array}$ \\
\hline & \multirow{7}{*}{$\begin{array}{l}\text { Patient Population: } \\
88 \text { patients enrolled in the O6BG } \\
+ \text { BCNU + RT group, } 88 \text { in the } \\
\text { BCNU + RT alone group, all adult } \\
\text { Treatment Regimen: } \\
\text { Patients were randomized to Arm } \\
1: \text { O6-BG + BCNU plus radiation } \\
\text { therapy or Arm } 2 \text { : BCNU plus } \\
\text { radiation therapy. Chemotherapy } \\
\text { began concurrently with radiation } \\
\text { therapy. The Arm } 1 \text { treatment } \\
\text { group received } 40 \mathrm{mg} / \mathrm{m} 2 \text { BCNU } \\
\text { six hours after the administration } \\
\text { of }\end{array}$} & & Toxicity: \\
\hline & & & \multirow{3}{*}{$\begin{array}{l}45 \text { grade } 4 \text { events, mostly hematologic. } \\
3 \text { treatment related deaths (renal } \\
\text { failure, sepsis, febrile neutropenia, } \\
\text { ARDS). } 10 \text { patients removed due to } \\
\text { SAE. Non O6BG patients - } 4 \text { treatment } \\
\text { related deaths (infection, ARDS, sudden } \\
\text { death), } 18 \text { with Grade } 4 \text { toxicities, } 9 \\
\text { removed due to toxicity. }\end{array}$} \\
\hline & & & \\
\hline & & & \\
\hline & & & Authors' Conclusions: \\
\hline & & & $\begin{array}{l}\text { Based on the doses and treatments } \\
\text { given to this cohort of patients, the } \\
\text { results of SWOG }\end{array}$ \\
\hline & & & S0001 do not support the hypothesis \\
\hline & \multirow{3}{*}{$\begin{array}{l}120 \mathrm{mg} / \mathrm{m} 2 \text { O6-BG intravenously } \\
\text { over one hour every six weeks. } \\
\text { The Arm } 2 \text { group received BCNU } \\
200 \mathrm{mg} / \mathrm{m} 2 \text { intravenously over } 1 \\
\text { hour every six weeks. A maximum } \\
\text { of seven cycles }\end{array}$} & & renders GBM more \\
\hline & & & $\begin{array}{l}\text { sensitive to alkylating therapy with } \\
\text { BCNU }\end{array}$ \\
\hline & & & Comments and Conclusions: \\
\hline & were allowed. & & $\begin{array}{l}\text { A randomized, control trial, but in a } \\
\text { smaller patient cohort, warrants Class II } \\
\text { designation. }\end{array}$ \\
\hline
\end{tabular}

Abbreviations: $\mathrm{BEV}=$ bevacizumab, OS = overall survival, $\mathrm{PFS}=$ progression free survival, $\mathrm{PFS} 6=$ six month progression free survival, $R R=$ response rate, $P D=$ progressive disease, $S D=$ stable disease, $C R$ = complete response, $\mathrm{PR}=$ partial response, $\mathrm{AE}=$ adverse event, $\mathrm{TMZ}=$ temozolomide, $\mathrm{GBM}=$ glioblastoma, $\mathrm{RT}=$ radiation therapy, $\mathrm{HTN}$ = hypertension, $\mathrm{CHF}=$ congestive heart failure, $\mathrm{VTE}=$ venous thromboembolism, $\mathrm{PE}=$ pulmonary embolism, $\mathrm{ALT}$ = alanine aminotransferase, $\mathrm{AST}=$ aspartate aminotransferace, 


\begin{tabular}{|c|c|c|c|}
\hline $\begin{array}{l}\text { Author } \\
\text { (year): }\end{array}$ & Description of study: & $\begin{array}{l}\text { Data } \\
\text { Class: }\end{array}$ & Conclusions: \\
\hline \multirow{10}{*}{$\begin{array}{l}\text { Odia et al } \\
(2015)\end{array}$} & Study Description: & III & Results: \\
\hline & \multirow{2}{*}{$\begin{array}{l}\text { Phase II trial of tamoxifen and } \\
\text { bortezomib in progressive } \\
\text { malignant glioma }\end{array}$} & & Median OS: 14.7 weeks \\
\hline & & & \multirow{2}{*}{$\begin{array}{l}\text { Response to treatment: No patients had } \\
\text { response at } 12 \text { weeks, and no patients } \\
\text { had stable disease. Three patients were } \\
\text { treated beyond six weeks. }\end{array}$} \\
\hline & Patient Population: & & \\
\hline & \multicolumn{2}{|l|}{$\begin{array}{l}30 \text { adult patients with progressive } \\
\text { GBM }\end{array}$} & . \\
\hline & \multirow[t]{5}{*}{$\begin{array}{l}\text { Treatment Regimen: Tamoxifen } \\
120 \mathrm{mg} \text { PO twice daily, } \\
\text { bortezomib } 1.3 \mathrm{mg} / \mathrm{m}^{\wedge} 2 \mathrm{IV} \text { on } \\
\text { days } 3,6,10,13,24,27,31 \text {, and } \\
34 \text { per six-week cycle. }\end{array}$} & & $\begin{array}{l}\text { Grouped toxicity for all malignant } \\
\text { glioma included lymphopenia (9.5\%), } \\
\text { hypophosphatemia (7.1\%), } \\
\text { thrombocytopenia (4.8\%), and } 2.4 \% \\
\text { each of hyponatremia, HA, dyspnea, } \\
\text { infection, somnolence, and DVT. Two } \\
\text { GBM patients were removed for } \\
\text { toxicities, the rest for disease } \\
\text { progression. }\end{array}$ \\
\hline & & & Authors' Conclusions: \\
\hline & & & $\begin{array}{l}\text { The study was closed due to poor } \\
\text { accrual and therapeutic futility. Poor } \\
\text { penetration across BBB of bortezomib } \\
\text { likely limited efficacy. }\end{array}$ \\
\hline & & & Comments and Conclusions: \\
\hline & & & $\begin{array}{l}\text { A nonrandomized trial in a moderate } \\
\text { cohort without control warrants Class } \\
\text { III designation. }\end{array}$ \\
\hline
\end{tabular}

Abbreviations: $\mathrm{BEV}=$ bevacizumab, OS = overall survival, $\mathrm{PFS}=$ progression free survival, $\mathrm{PFS} 6=$ six month progression free survival, $R R=$ response rate, $P D=$ progressive disease, $S D=$ stable disease, $C R$ = complete response, $\mathrm{PR}=$ partial response, $\mathrm{AE}=$ adverse event, $\mathrm{TMZ}=$ temozolomide, $\mathrm{GBM}=$ glioblastoma, $\mathrm{RT}=$ radiation therapy, $\mathrm{HTN}$ = hypertension, $\mathrm{CHF}=$ congestive heart failure, $\mathrm{VTE}=$ venous thromboembolism, $\mathrm{PE}=$ pulmonary embolism, $\mathrm{ALT}$ = alanine aminotransferase, $\mathrm{AST}=$ aspartate aminotransferace, 


\begin{tabular}{|c|c|c|c|}
\hline $\begin{array}{l}\text { Author } \\
\text { (year): }\end{array}$ & Description of study: & $\begin{array}{l}\text { Data } \\
\text { Class: }\end{array}$ & Conclusions: \\
\hline \multirow{10}{*}{$\begin{array}{l}\text { Batchelor } \\
\text { et al (2013) }\end{array}$} & Study Description: & I & Results: \\
\hline & \multirow{2}{*}{$\begin{array}{l}\text { Phase III randomized trial of } \\
\text { cediranib monotherapy vs } \\
\text { combination with lomustine vs } \\
\text { lomustine alone in progressive } \\
\text { GBM. }\end{array}$} & & $\begin{array}{l}\text { Median OS: cediranib monotherapy } 8 \\
\text { mos, cediranib plus lomustine } 9.4 \text { mos, } \\
\text { lomustine alone } 9.8 \text { mos }\end{array}$ \\
\hline & & & \multirow{2}{*}{$\begin{array}{l}\text { Response to treatment: Primary end } \\
\text { point of progression-free survival was } \\
\text { not significantly different in any group. }\end{array}$} \\
\hline & Patient Population: & & \\
\hline & \multicolumn{2}{|l|}{$\begin{array}{l}325 \text { adulta patients with } \\
\text { progressive GBM }\end{array}$} & Toxicity: \\
\hline & \multirow{5}{*}{$\begin{array}{l}\text { Treatment Regimen: Randomly } \\
\text { assigned }(2: 2: 1) \text { to }(1) \text { cediranib } \\
30 \mathrm{mg} \text { monotherapy, }(2) \text { cediranib } \\
20 \mathrm{mg} \text { plus lomustine } 110 \\
\mathrm{mg} / \mathrm{m}^{\wedge} 2 \text { or (3) lomustine } 110 \\
\mathrm{mg} / \mathrm{m}^{\wedge} 2 \text { plus placebo. }\end{array}$} & & $\begin{array}{l}\text { Grade } 3 \text { or } 4 \text { thrombocytopenia and } \\
\text { neutropenia in } 38 \% \text { and } 20 \% \text { of cases, } \\
\text { respectively, in combination arm, } 2 \% \\
\text { and } 1 \% \text { in cediranib alone arm, and } \\
22 \% \text { and } 3 \% \text { in lomustine alone arm. }\end{array}$ \\
\hline & & & Authors' Conclusions: \\
\hline & & & $\begin{array}{l}\text { This study did not meet its primary end } \\
\text { point of PFS prolongation with } \\
\text { cediranib either as monotherapy or in } \\
\text { combination with lomustine vs } \\
\text { lomustine in patients with progressive } \\
\text { GBM. }\end{array}$ \\
\hline & & & Comments and Conclusions: \\
\hline & & & $\begin{array}{l}\text { A large, prospectively randomized } \\
\text { study warrants Class I designation. }\end{array}$ \\
\hline \multicolumn{4}{|c|}{$\begin{array}{l}\text { Abbreviations: } \mathrm{BEV}=\text { bevacizumab, } \mathrm{OS}=\text { overall survival, } \mathrm{PFS}=\text { progression free survival, } \mathrm{PFS} 6=\mathrm{six} \\
\text { month progression free survival, } \mathrm{RR}=\text { response rate, } \mathrm{PD}=\text { progressive disease, } \mathrm{SD}=\text { stable disease, } \mathrm{CR} \\
=\text { complete response, } \mathrm{PR}=\text { partial response, } \mathrm{AE}=\text { adverse event, } \mathrm{TMZ}=\text { temozolomide, } \mathrm{GBM}= \\
\text { glioblastoma, } \mathrm{RT}=\text { radiation therapy, } \mathrm{HTN}=\text { hypertension, } \mathrm{CHF}=\text { congestive heart failure, } \mathrm{VTE}= \\
\text { venous thromboembolism, } \mathrm{PE}=\text { pulmonary embolism, } \mathrm{ALT}=\text { alanine aminotransferase, } \mathrm{AST}= \\
\text { aspartate aminotransferace, }\end{array}$} \\
\hline
\end{tabular}

A total of 8 papers were reviewed describing combination therapy with targeted therapy and cytotoxic therapy.[74-81] Two studies included the use of tamoxifen.[75; 81] Four of the studies included the use of nitrosoureas like lomustine and BCNU.[77-80] The remainder of studies evaluated the use of single agent targeted therapies with other cytotoxic chemotherapies.[72; 74; 76]

\section{Tamoxifen}

Tamoxifen is a selective estrogen-receptor modulator that has been shown to have some effect in glioblastoma patients.[82-84] Di Cristofori et al studied 32 adult patients receiving TMZ and tamoxifen. [81] Median OS was 17.5 months, with methylated MGMT patients showing a 20.5 month mOS and 15 months in unmethylated patients. Methylated patients had a time to progression interval of 11 months 
and 7.5 months in unmethylated patients, with a median time to progression of 9.5 months. The second time to progression (after TMZ + tamoxifen) was another 7 months. Authors concluded there was a benefit to the dual treatment regimen in both patient groups. This was designated Class III evidence as the study was small and without a control group. Next, Odia et al combined tamoxifen with bortezomib (inhibits the mammalian 26S proteasome involved in the ubiquitin-proteasome pathway) in 30 patients. [75] They closed their study early and deemed bortezomib to be of limited efficacy due to poor crossing of the blood brain barrier, with minimal comment on tamoxifen. This was designated Class III as well with lack of a control group and a nonrandomized design.

\section{Nitrosoureas}

Batchelor et al performed a phase III randomized trial using cediranib monotherapy, cediranib and lomustine,lomustine or lomustine alone in 325 patients.[80] The authors concluded the study did not produce a prolongation of mOS PFS either in combination therapies or as monotherapy of either lomustine or cediranib. As it was a large, prospective, randomized study, this warranted Class I designation. Blumenthal et al performed a phase III study of RT with 06-benzylguanine with BCNU versus radiotherapy and BCNU alone with comparison to methylation status.[79] Results in 88 patients showed no significant difference between the treatment arms and methylation status. They concluded that extrinsic depletion of MGMT does not necessarily make glioblastoma more susceptible to BCNU alkylation therapy. The moderate size and randomized, control trial design portended a Class II designation

Brandes et al performed a phase II randomized study evaluating galunisertib (TGF-b inhibitor) monotherapy vs combination therapy with lomustine versus lomustine monotherapy in 158 patients.[78] mOS was 6.7 months in the combination group, 8 months with galunisertib monotherapy, and 7.5 months in lomustine with placebo. The authors concluded that combination therapy failed to show any overall improvement of OS relative to the placebo plus lomustine group. This warranted Class II designation for the randomized, control trial design with a moderate sizedpatient cohort. Duerinck et al evaluated axitinib (a small molecule tyrosine kinase inhibitor) monotherapy in comparison to combination with lomustine in 79 patients.[77] The authors concluded that axitinib improved response rate but there was no overall benefit as combination therapy, with the small case series design designating the data Class III.

\section{Kinase Inhibitors}

Grisanti et al evaluated Irinotecan in conjunction with sunitinib.[76] They evaluated a small number of patients $(n=6)$ and never reached their PFS6 endpoint before terminating the trial early, generating Class III data. Schiff et al evaluated temsirolimus with sorafenib (protein kinase inhibitor with activity against VEGFR, PDGFR, RAF kinases).[72] The study found toxicity prominent among all arms of the trial requiring dose reductions, resulting in a lack of efficacy compared to single agent administration. The combined Phase I and II trial was without randomization and there was no control group, generating a Class III designation. 
Wang at al evaluated irinotecan with apatinib (Tyrosine Kinase inhibitor selective for VEGFR2) in 10 patients, 6 of which had glioblastoma.[74] The conclusion was that the combination may be promising, but results were limited due to a small patient cohort without randomization or control group, giving it Class III designation.

\section{Synthesis:}

In the prior guidelines, there were mixed reviews regarding combined targeted and cytotoxic therapy regimens, without any studies showing reproducible proof of positive PFS or OS benefit. In this update, tamoxifen studies yielded Class III data and no overall benefit. In the data for nitrosoureas, all the Class I and Class II evidence available revealed there was no benefit beyond monotherapy with a targeted agent and at times with the nitrosourea alone, thus not identifying any synergistic effect. The same held true for the kinase inhibitors combined with cytotoxic agents where all data was Class III showing no overall efficacy beyond monotherapies. This did not provide sufficient evidence to make a recommendation regarding targeted therapies in combination with cytotoxic agents. This conclusion is not meant to suggest such combination studies are not worthy of further investigation and it is suggested that when available, and patients meet inclusion criteria, they be enrolled in properly designed studies of targeted agents combined with cytotoxic agents.

Question 6: In adults with progressive glioblastoma is the use of immunotherapy alone superior to standard salvage cytotoxic chemotherapy as measured by progression free survival and overall survival?

Prior Recommendations: In the previously published guidelines on the role of targeted therapies in the management of progressive glioblastoma in adults, immunotherapeutic agents were not reviewed.

\section{Recommendation}

There is insufficient evidence to support a recommendation regarding this question.

\section{Study selection and characteristics of the updated search:}

The initial search strategy included 904 candidate articles. A total of 31 articles qualified for full text review. From these, 26 articles met eligibility criteria and were included in the final review for question 6 and are included in Table 6 below. [71; 85-111] 
The role of immunotherapy in progressive GBM

Author (year): Description of study:

Cloughesy et al (2019)

Study Description:
Multi-institution, randomized, open-label pilot study of pembrolizumab in patients with progressive, surgically resectable glioblastoma

Patient Population:

35 adult patients with progressive GBM, 16 in neoadjuvant and 19 in adjuvant only

Treatment Regimen:

Patients randomized to the neoadjuvant + adjuvant treatment group received pembrolizumab 200

mg intravenous infusions $14 \pm 5$ days prior to scheduled surgical resection. Tumor resection was performed according to institutional standards. After recovery from surgery, patients

received pembrolizumab $200 \mathrm{mg}$ intravenous infusions every 3 weeks until tumor

progression or an adverse event requiring study drug discontinuation. The adjuvant only group received the same regimen only after surgery.
Data Class:

III

Results:

Neoadjuvant OS: 13.7m, Adjuvant OS: $7.5 \mathrm{~m}$

median PFS-6: 3.3m neoadjuvant, $2.4 \mathrm{~m}$ adjuvant

Toxicity:

10 patients with grade $3 / 4$ toxicity in neoadjuvant, 7 in adjuvant. No neoadjuvant patients had surgery delayed due to toxicity. Two patients in neoadjuvant group required discontinuation of pembrolizumab, one for ALT elevation, another for pneumonitis.

\section{Authors'}

Conclusions:

In this study, PD-1 monoclonal antibody blockade was associated with statistically

significant improvements in overall survival and progression-free survival when administered in the neoadjuvant setting to patients with progressive glioblastoma, in

Abbreviations: BEV = bevacizumab, OS = overall survival, PFS = progression free survival, PFS6 = six month progression free survival, $R R=$ response rate, $P D=$ progressive disease, $S D=$ stable disease, $C R$ = complete response, $\mathrm{PR}=$ partial response, $\mathrm{AE}=$ adverse event, $\mathrm{TMZ}=$ temozolomide, $\mathrm{GBM}=$ glioblastoma, $\mathrm{RT}$ = radiation therapy, $\mathrm{HTN}=$ hypertension, $\mathrm{CHF}=$ congestive heart failure, VTE = venous thromboembolism, PE = pulmonary embolism, ALT = alanine aminotransferase, $A S T$ = aspartate aminotransferace, 
Data Conclusions:

Class:
Narita et al (2019)

\section{Study Description:}

Prospective randomized, double-blind Phase III trial for personalized peptide vaccine

Patient Population:

Adult HLA-A24 positive patients with supratentorial progressive GBM with positive IgG responses to at least 2 of 12 warehouse peptides in pre-vaccination plasma and good functional status randomized to vaccination $(n=58)$ or placebo $(n=30)$.

Treatment Regimen:

Four of the 12 warehouse peptides selected based on the patient's pre-existing peptide-specific IgG levels or corresponding placebos were injected subcutaneously once weekly for 12 weeks, followed by biweekly vaccinations until disease progression. comparison to the adjuvant only group.

Comments and Conclusions:

Classified as Class II due to its multiinstitutional randomized design with a larger patient population.

Results:

Median OS: 8.4 months

Response to treatment: immune related response (IR) of 3 vs 0 IR partial response, 21 vs 9 IR stable disease and 33 vs 19 IR progressive disease for 57 PPV and 27 placebo patients, respectively.

Toxicity:

In the 58 PPV and 30 placebo patients there were 340 or 120 events in 54 or 26 patients $(93.11 \%$ or $86.7 \%)$. There was one grade 3 PPVrelated pulmonary embolism in the trial.

Authors'

Conclusions:

This phase III trial met neither the primary nor secondary endpoints or OS from day of

Abbreviations: $\mathrm{BEV}=$ bevacizumab, $\mathrm{OS}=$ overall survival, $\mathrm{PFS}=$ progression free survival, $\mathrm{PFS} 6=\mathrm{six}$ month progression free survival, $\mathrm{RR}=$ response rate, $\mathrm{PD}=$ progressive disease, $\mathrm{SD}=$ stable disease, $\mathrm{CR}$ = complete response, $\mathrm{PR}=$ partial response, $\mathrm{AE}$ = adverse event, $\mathrm{TMZ}=$ temozolomide, $\mathrm{GBM}=$ glioblastoma, $\mathrm{RT}=$ radiation therapy, $\mathrm{HTN}=$ hypertension, $\mathrm{CHF}=$ congestive heart failure, $\mathrm{VTE}=$ venous thromboembolism, $\mathrm{PE}=$ pulmonary embolism, $\mathrm{ALT}$ = alanine aminotransferase, $\mathrm{AST}=$ aspartate aminotransferace, 


\begin{tabular}{|c|c|c|c|}
\hline Author (year): & Description of study: & $\begin{array}{l}\text { Data } \\
\text { Class: }\end{array}$ & Conclusions: \\
\hline & & & $\begin{array}{l}\text { randomization } \\
\text { (primary), } 1 \text {-year } \\
\text { survival rate, } \\
\text { antitumor responses, } \\
\text { PFS, PFS at 6 } \\
\text { months, peptide- } \\
\text { specific lgG } \\
\text { responses and } \\
\text { cytotoxic T } \\
\text { lymphocyte (CTL) } \\
\text { activity (all } \\
\text { secondary). }\end{array}$ \\
\hline & & & $\begin{array}{l}\text { Comments and } \\
\text { Conclusions: }\end{array}$ \\
\hline & & & $\begin{array}{l}\text { A prospective, } \\
\text { randomized phase III, } \\
\text { double blinded trial } \\
\text { meets criteria for } \\
\text { Class I designation. }\end{array}$ \\
\hline \multirow{8}{*}{$\begin{array}{l}\text { Schalper et al } \\
(2019)\end{array}$} & Study Description: & \multirow[t]{8}{*}{ III } & Results: \\
\hline & $\begin{array}{l}\text { Prospective, single-arm phase II trial of nivolumab } \\
\text { in resectable glioblastoma }\end{array}$ & & \multirow{2}{*}{$\begin{array}{l}\text { Median OS: } 7.3 \text { mos } \\
\text { (mixed patient } \\
\text { cohort, progressive } \\
\text { GBM patients not } \\
\text { extractable) }\end{array}$} \\
\hline & Patient Population: & & \\
\hline & $\begin{array}{l}\text { Adult patients undergoing surgery for primary ( } 3 \\
\text { patients) or progressive ( } 27 \text { patients) } \\
\text { glioblastoma }\end{array}$ & & \multirow{3}{*}{$\begin{array}{l}\text { Response to } \\
\text { treatment: Samples } \\
\text { from patients treated } \\
\text { with nivolumab } \\
\text { showed upregulation } \\
\text { of numerous } \\
\text { immune-related } \\
\text { transcripts, indicating } \\
\text { prominent } \\
\text { immunomodulatory } \\
\text { effects that were } \\
\text { elicited by adjuvant } \\
\text { treat- ment. }\end{array}$} \\
\hline & Treatment Regimen: & & \\
\hline & \multirow[t]{3}{*}{$\begin{array}{l}3 \mathrm{mg} \mathrm{kg} \mathrm{k}^{\wedge}-1 \text { dose of nivolumab given } 2 \text { weeks } \\
(+/-3 \text { days) before surgery and then postsurgical } \\
\text { doses of nivolumab every two weeks until } \\
\text { radiologic progression or unacceptable toxicity. }\end{array}$} & & \\
\hline & & & Toxicity: \\
\hline & & & $\begin{array}{l}\text { For the whole cohort, } \\
\text { only one patient } \\
\text { experienced a grade } \\
>2 \text { immune-related }\end{array}$ \\
\hline \multicolumn{4}{|c|}{$\begin{array}{l}\text { Abbreviations: } \mathrm{BEV}=\text { bevacizumab, } \mathrm{OS}=\text { overall survival, } \mathrm{PFS}=\text { progression free survival, } \mathrm{PFS} 6=\mathrm{six} \\
\text { month progression free survival, } \mathrm{RR}=\text { response rate, } \mathrm{PD}=\text { progressive disea se, } \mathrm{SD}=\text { stable disease, } \mathrm{CR} \\
=\text { complete response, } \mathrm{PR}=\text { partial response, } \mathrm{AE}=\text { adverse event, } \mathrm{TMZ}=\text { temozolomide, } \mathrm{GBM}= \\
\text { glioblastoma, } \mathrm{RT}=\text { radiation therapy, } \mathrm{HTN}=\text { hypertension, } \mathrm{CHF}=\text { congestive heart failure, } \mathrm{VTE}= \\
\text { venous thromboembolism, } \mathrm{PE}=\text { pulmonary embolism, } \mathrm{ALT}=\text { alanine aminotransferase, } \mathrm{AST}= \\
\text { aspartate aminotransferace, }\end{array}$} \\
\hline
\end{tabular}




\begin{tabular}{|c|c|c|c|}
\hline Author (year): & Description of study: & $\begin{array}{l}\text { Data } \\
\text { Class: }\end{array}$ & Conclusions: \\
\hline & & & $\begin{array}{l}\text { adverse event } \\
\text { (elevated serum } \\
\text { alanine } \\
\text { aminotransferase } \\
\text { and aspartate } \\
\text { aminotransferase) } \\
\text { and one patient with } \\
\text { grade } 2 \\
\text { hyperthyroidism. Two } \\
\text { patients had bleeding } \\
\text { episodes after } \\
\text { nivolomab while } \\
\text { waiting for surgery. } \\
\text { An additional patient } \\
\text { had a bleeding } \\
\text { episode after surgery, } \\
\text { two months later in } \\
\text { the context of } \\
\text { documented disease } \\
\text { progression. }\end{array}$ \\
\hline & & & $\begin{array}{l}\text { Authors' } \\
\text { Conclusions: }\end{array}$ \\
\hline & & & $\begin{array}{l}\text { There was no } \\
\text { obvious clinical } \\
\text { benefit substantiated } \\
\text { following salvage } \\
\text { surgery at recurrence. }\end{array}$ \\
\hline & & & $\begin{array}{l}\text { Comments and } \\
\text { Conclusions: }\end{array}$ \\
\hline & & & $\begin{array}{l}\text { A single-arm study in } \\
\text { a small group of } \\
\text { patients without } \\
\text { control warrants } \\
\text { Class III designation. }\end{array}$ \\
\hline
\end{tabular}

Abbreviations: $\mathrm{BEV}=$ bevacizumab, OS = overall survival, $\mathrm{PFS}=$ progression free survival, $\mathrm{PFS} 6=$ six month progression free survival, $R R=$ response rate, $P D=$ progressive disease, $S D=$ stable disease, $C R$ = complete response, $\mathrm{PR}=$ partial response, $\mathrm{AE}$ = adverse event, $\mathrm{TMZ}=$ temozolomide, $\mathrm{GBM}=$ glioblastoma, $\mathrm{RT}=$ radiation therapy, $\mathrm{HTN}$ = hypertension, $\mathrm{CHF}=$ congestive heart failure, $\mathrm{VTE}=$ venous thromboembolism, $\mathrm{PE}=$ pulmonary embolism, $\mathrm{ALT}$ = alanine aminotransferase, $\mathrm{AST}=$ aspartate aminotransferace, 
Tsuboi et al (2019)
Study Description:

Phase I trial of Wilms' tumor 1 (WT1) HLA I and II peptides for progressive malignant glioma

Patient population:

12 adult patients with progressive glioblastoma were treated with WT1 HLA I and II peptides.

Treatment Regimen:

WT1 HLA class II peptide was dose escalated from 0.75 to 1.5 and then to $3.0 \mathrm{mg} /$ body while doses of WT1 HLA class I peptide remained at 3.0 mg. $3+3$ cohort design was used. Patients received intradermal administration of a coctail peptide and one of WT1 HLA class II peptides as the vaccine, followed by a vaccine containing only the WT1 HLA class I peptide the second week.

These two regimens were alternated every week. If safety was determined at 6 weeks, then vaccination continued at 2-4-week intervals until dose-limiting toxicity. vaccine comprising $3 \mathrm{mg}$ of WT1 HLA class I

III

\section{Results:}

Median OS of the 9 patients with progressive GBM: 24.7 weeks $(6.175$ mos)

Response to treatment: Three patients had SD and 6 had PD at 12 weeks.

Toxicity:

All patients developed Grade 1 skin reactions at the injection site. No grade 3 or 4 toxicity or dose-limiting toxicity was observed.

Authors' Conclusions:

The safety of WT1 HLA class I and II peptide for malignant gliomas was verified.

Comments and Conclusions:

A phase 1 trial with few patients and no controls warrants Class III designation.

Desjardins et Study Description: al (2018)
Phase I dose escalation trial of intratumoral CED of recombinant nonpathogenic polio-rhinovirus chimera (PVSRIPO)
Patient Population:

III

Results:

OS reached a plateau of $21 \%$ at 24 months that was sustained at 36 months.

Toxicity:

Abbreviations: $\mathrm{BEV}$ = bevacizumab, OS = overall survival, $\mathrm{PFS}=$ progression free survival, $\mathrm{PFS} 6$ = six month progression free survival, $\mathrm{RR}=$ response rate, $\mathrm{PD}=$ progressive disease, $\mathrm{SD}=$ stable disease, $\mathrm{CR}$ = complete response, $\mathrm{PR}=$ partial response, $\mathrm{AE}=$ adverse event, $\mathrm{TMZ}=$ temozolomide, $\mathrm{GBM}=$ glioblastoma, $\mathrm{RT}=$ radiation therapy, $\mathrm{HTN}$ = hypertension, $\mathrm{CHF}=$ congestive heart failure, $\mathrm{VTE}=$ venous thromboembolism, $\mathrm{PE}=$ pulmonary embolism, $\mathrm{ALT}$ = alanine aminotransferase, $\mathrm{AST}=$ aspartate aminotransferace, 


\begin{tabular}{|c|c|c|c|}
\hline Author (year): & Description of study: & $\begin{array}{l}\text { Data } \\
\text { Class: }\end{array}$ & Conclusions: \\
\hline & 61 progressive GBM pts & & \multirow{3}{*}{$\begin{array}{l}9 \% \text { of the patients } \\
\text { had a PVSRIPO- } \\
\text { related adverse event } \\
\text { of grade } 3 \text { or higher. } \\
\text { Dose level }-1 \\
\text { ( } 5.0 \times 107 \text { TCID } 50) \\
\text { was identified as the } \\
\text { phase II dose. }\end{array}$} \\
\hline & Treatment Regimen: & & \\
\hline & \multirow{5}{*}{$\begin{array}{l}\text { Dose escalation followed by dose expansion } \\
\text { evaluating seven doses ranging between } 10^{\wedge} 7 \\
\text { and } 10^{\wedge} 1050 \% \text { tissue-culture infectious doses } \\
\text { (TCID 50) with intratumoral CED of the } \\
\text { recombinant nonpathogenic polio-rhinovirus } \\
\text { chimera (PVSRIPO). }\end{array}$} & & \\
\hline & & & $\begin{array}{l}\text { Authors' } \\
\text { Conclusions: }\end{array}$ \\
\hline & & & $\begin{array}{l}\text { Intratumoral infusion } \\
\text { of PVSRIPO in } \\
\text { patients with } \\
\text { progressive WHO } \\
\text { Grade IV malignant } \\
\text { glioma confirmed the } \\
\text { absence of } \\
\text { neurovirulent } \\
\text { potential. The } \\
\text { survival rate among } \\
\text { patients with } \\
\text { PVSRIPO } \\
\text { immunotherapy was } \\
\text { higher at } 24 \text { and } 36 \\
\text { months than the rate } \\
\text { among historical } \\
\text { controls. }\end{array}$ \\
\hline & & & $\begin{array}{l}\text { Comments and } \\
\text { Conclusions: }\end{array}$ \\
\hline & & & $\begin{array}{l}\text { While this study } \\
\text { included a moderate } \\
\text { number of patients, it } \\
\text { was designed as a } \\
\text { dose-escalation and } \\
\text { dose-expansion } \\
\text { phase I trial without a } \\
\text { control. }\end{array}$ \\
\hline
\end{tabular}

Abbreviations: $\mathrm{BEV}=$ bevacizumab, OS = overall survival, $\mathrm{PFS}=$ progression free survival, $\mathrm{PFS} 6=$ six month progression free survival, $\mathrm{RR}=$ response rate, $\mathrm{PD}=$ progressive disease, $\mathrm{SD}=$ stable disease, $\mathrm{CR}$ = complete response, $\mathrm{PR}=$ partial response, $\mathrm{AE}=$ adverse event, $\mathrm{TMZ}=$ temozolomide, $\mathrm{GBM}=$ glioblastoma, $\mathrm{RT}=$ radiation therapy, $\mathrm{HTN}$ = hypertension, $\mathrm{CHF}=$ congestive heart failure, $\mathrm{VTE}=$ venous thromboembolism, $\mathrm{PE}=$ pulmonary embolism, $\mathrm{ALT}$ = alanine aminotransferase, $\mathrm{AST}=$ aspartate aminotransferace, 


\begin{tabular}{llll}
\hline Author (year): & Description of study: & Data & Conclusions: \\
& Class: &
\end{tabular}

Lukas et al Study Description:

(2018)
Open-label phase 1 dose-escalation study in pts treated with Atezolizumab.

Patient Population:

16 patients with progressive GBM.

Treatment Regimen:

Atezolizumab was administered $1200 \mathrm{mg}$ IV every 3 weeks until progression/toxicity.
III

Results:

One patient experienced a PR, 3 had SD.

Median OS: 4.2 mos

Toxicity:

All 16 patients had at least $1 \mathrm{AE}$. 3 patients had grade 3 asthenia, increased aspartate aminotransferase and brain edema. All patients discontinued due to PD.

Authors'

Conclusions:

Atezolizumab was safe and well tolerated.

Comments and Conclusions:

A phase 1 dose escalation trial in a limited number of patients warrants class III designation.

Mantica et al Study Description: (2018)

Retrospective, single institution trial of nivolumab

Patient Population:

Adult patients with progressive high-grade glioma with any prior therapy receiving greater than one cycle of nivolumab with at least one posttreatment radiographic follow-up. $(n=37$ with progressive GBM)

Treatment Regimen:
Results:

Median PFS: 4.6 months

Median OS: 6.5 months

Response to treatment: CR: 0 PR: 0 SD: not specific for Grade IV but $72 \%$ of full cohort at 2-

Abbreviations: $\mathrm{BEV}=$ bevacizumab, $\mathrm{OS}=$ overall survival, $\mathrm{PFS}=$ progression free survival, $\mathrm{PFS} 6=\mathrm{six}$ month progression free survival, $R R=$ response rate, $P D=$ progressive disease, $S D=$ stable disease, $C R$ = complete response, $\mathrm{PR}=$ partial response, $\mathrm{AE}$ = adverse event, $\mathrm{TMZ}=$ temozolomide, $\mathrm{GBM}=$ glioblastoma, $\mathrm{RT}=$ radiation therapy, $\mathrm{HTN}$ = hypertension, $\mathrm{CHF}=$ congestive heart failure, $\mathrm{VTE}=$ venous thromboembolism, $\mathrm{PE}=$ pulmonary embolism, $\mathrm{ALT}$ = alanine aminotransferase, $\mathrm{AST}=$ aspartate aminotransferace, 


\begin{tabular}{|c|c|c|c|}
\hline Author (year): & Description of study: & $\begin{array}{l}\text { Data } \\
\text { Class: }\end{array}$ & Conclusions: \\
\hline & \multirow[t]{7}{*}{$\begin{array}{l}\text { Patients received nivolumab IV } 3 \mathrm{mg} / \mathrm{kg} \text { over } 60 \\
\text { min once every } 2 \text { weeks. }\end{array}$} & & $\begin{array}{l}\text { month assessment } \\
(36 / 50) \text {. }\end{array}$ \\
\hline & & & Toxicity: \\
\hline & & & $\begin{array}{l}\text { Includes data on } \\
\text { Grade III and IV } \\
\text { combined, including } \\
39 \text { treatment-related } \\
\text { AE, and included } \\
\text { fatigue }(n=8), \\
\text { constipation }(n=5), \\
\text { Grade } 3-4 \mathrm{AE}(\mathrm{n}=4), \\
3 \text { autoimmune } \\
\text { toxicities and several } \\
\text { varied neurological } \\
\text { complications }\end{array}$ \\
\hline & & & $\begin{array}{l}\text { Authors' } \\
\text { Conclusions: }\end{array}$ \\
\hline & & & $\begin{array}{l}\text { Treatment with } \\
\text { nivolumab has a } \\
\text { manageable safety } \\
\text { profile consistent } \\
\text { with that of other PD- } \\
1 \text { agents, with } \\
\text { disease stabilization } \\
\text { in a small subset of } \\
\text { patients including in } \\
\text { the bevacizumab } \\
\text { refractory setting. }\end{array}$ \\
\hline & & & $\begin{array}{l}\text { Comments and } \\
\text { Conclusions: }\end{array}$ \\
\hline & & & $\begin{array}{l}\text { A single-center } \\
\text { nonrandomized trial } \\
\text { warrants Class III } \\
\text { designation. }\end{array}$ \\
\hline
\end{tabular}

Abbreviations: $\mathrm{BEV}=$ bevacizumab, OS = overall survival, $\mathrm{PFS}=$ progression free survival, $\mathrm{PFS} 6=$ six month progression free survival, $R R=$ response rate, $P D=$ progressive disease, $S D=$ stable disease, $C R$ = complete response, $\mathrm{PR}=$ partial response, $\mathrm{AE}=$ adverse event, $\mathrm{TMZ}=$ temozolomide, $\mathrm{GBM}=$ glioblastoma, $\mathrm{RT}=$ radiation therapy, $\mathrm{HTN}$ = hypertension, $\mathrm{CHF}=$ congestive heart failure, $\mathrm{VTE}=$ venous thromboembolism, $\mathrm{PE}=$ pulmonary embolism, $\mathrm{ALT}$ = alanine aminotransferase, $\mathrm{AST}=$ aspartate aminotransferace, 


\begin{tabular}{|c|c|c|c|}
\hline Author (year): & Description of study: & $\begin{array}{l}\text { Data } \\
\text { Class: }\end{array}$ & Conclusions: \\
\hline \multirow{11}{*}{$\begin{array}{l}\text { Shibao et al } \\
\text { (2018) }\end{array}$} & Study Description: & III & Results: \\
\hline & $\begin{array}{l}\text { Prospective, Phase I trial of vaccine targeting } \\
\text { angiogenesis factors in progressive GBM. }\end{array}$ & & $\begin{array}{l}\text { Median OS: not } \\
\text { reported }\end{array}$ \\
\hline & Patient Population: & & \multirow{3}{*}{$\begin{array}{l}\text { Response to } \\
\text { treatment: Patient } \\
\text { received a mean of } \\
11.5(+/-3.46) \\
\text { peptide vaccination. } \\
\text { Two patient achieved } \\
\text { SD and six had PD at } \\
\text { the end of eight } \\
\text { vaccinations. }\end{array}$} \\
\hline & $\begin{array}{l}\text { Nine adult ( } 16-80 \text { years) patients with } \\
\text { progressive high-grade glioma including GBM } \\
\text { with HLA-A* } 2402 \text { genotyping, good performance } \\
\text { status, and at least four weeks since last } \\
\text { treatment. }\end{array}$ & & \\
\hline & Treatment Regimen: & & \\
\hline & \multirow{6}{*}{$\begin{array}{l}2 \mathrm{mg} / \mathrm{kg} \text { body weight (previously determined } \\
\text { preferred dose) of VEGFR1 and VEGFR2 were } \\
\text { emulsified in incomplete Freund's adjuvant and } \\
\text { admi9nistered subcutaneously close to axillary or } \\
\text { inguinal lymph node } 8 \text { times weekly. }\end{array}$} & & Toxicity: \\
\hline & & & $\begin{array}{l}\text { No major toxicity } \\
\text { was fouhd. All eight } \\
\text { patents developed a } \\
\text { skin reaction at the } \\
\text { injection site, and } \\
\text { one patient } \\
\text { developed an ulcer at } \\
\text { the injection site. }\end{array}$ \\
\hline & & & $\begin{array}{l}\text { Authors' } \\
\text { Conclusions: }\end{array}$ \\
\hline & & & $\begin{array}{l}\text { Our findings } \\
\text { demonstrated the } \\
\text { safety and } \\
\text { immunogenicity, as } \\
\text { well as preliminary } \\
\text { efficacy, of this } \\
\text { approach. }\end{array}$ \\
\hline & & & $\begin{array}{l}\text { Comments and } \\
\text { Conclusions: }\end{array}$ \\
\hline & & & $\begin{array}{l}\text { A small, } \\
\text { nonrandomized } \\
\text { cohort without } \\
\text { control warrants } \\
\text { Class III designation. }\end{array}$ \\
\hline
\end{tabular}

Abbreviations: $\mathrm{BEV}=$ bevacizumab, OS = overall survival, $\mathrm{PFS}=$ progression free survival, $\mathrm{PFS} 6=$ six month progression free survival, $\mathrm{RR}=$ response rate, $\mathrm{PD}=$ progressive disease, $\mathrm{SD}=$ stable disease, $\mathrm{CR}$ = complete response, $\mathrm{PR}=$ partial response, $\mathrm{AE}=$ adverse event, $\mathrm{TMZ}=$ temozolomide, $\mathrm{GBM}=$ glioblastoma, $\mathrm{RT}=$ radiation therapy, $\mathrm{HTN}$ = hypertension, $\mathrm{CHF}=$ congestive heart failure, $\mathrm{VTE}=$ venous thromboembolism, $\mathrm{PE}=$ pulmonary embolism, $\mathrm{ALT}$ = alanine aminotransferase, $\mathrm{AST}=$ aspartate aminotransferace, 


\begin{tabular}{|c|c|c|c|}
\hline Author (year): & Description of study: & $\begin{array}{l}\text { Data } \\
\text { Class: }\end{array}$ & Conclusions: \\
\hline $\begin{array}{l}\text { Ahmed et al } \\
\text { (2017) }\end{array}$ & $\begin{array}{l}\text { Study Description: } \\
\text { Phase } 1 \text { open-label dose-escalation study testing } \\
\text { HER2-specific chimeric antigen receptor-modified } \\
\text { virus-specific T Cells for safety and anti-GBM } \\
\text { activity. } \\
\text { Patient Population: Progressive HER2-positive } \\
\text { GBM ( } \mathrm{n}=17 \text {, but only } 10 \text { patients }>18 \mathrm{y}) \text {. } \\
\text { Treatment Regimen: received one or more } \\
\text { infusions of HER2-CAR VSTs }\left(1 \times 10^{\wedge} 6 / \mathrm{m}^{\wedge} 2 \text { to }\right. \\
\left.1 \times 10^{\wedge} 8 / \mathrm{m}^{\wedge} 2\right) \text { without prior lymphodepletion }\end{array}$ & III & $\begin{array}{l}\text { Results: } \\
\text { Median time to } \\
\text { progression: } 3.5 \\
\text { months. } \\
\text { Median OS: } 11.1 \\
\text { months after } \\
\text { infusion, } 24.5 \\
\text { months after } \\
\text { diagnosis. } \\
\text { Toxicity: No dose- } \\
\text { limiting toxicity. } 2 \\
\text { patients had seizures } \\
\text { and headaches } \\
\text { Authors' } \\
\text { Conclusions: } \\
\text { Infusion of } \\
\text { autologous HER2- } \\
\text { CAR VSTs is safe } \\
\text { and can be } \\
\text { associated with } \\
\text { clinical benefit for } \\
\text { patients with } \\
\text { progressive } \\
\text { glioblastoma. } \\
\text { Comments and } \\
\text { Conclusions: } \\
\text { This study was } \\
\text { classified as Class III } \\
\text { due to a small } \\
\text { sample size and it } \\
\text { was a Phase I, dose- } \\
\text { escalation, } \\
\text { nonrandomized } \\
\text { sample. }\end{array}$ \\
\hline
\end{tabular}

Abbreviations: $\mathrm{BEV}=$ bevacizumab, OS = overall survival, $\mathrm{PFS}=$ progression free survival, $\mathrm{PFS} 6=$ six month progression free survival, $\mathrm{RR}=$ response rate, $\mathrm{PD}=$ progressive disease, $\mathrm{SD}=$ stable disease, $\mathrm{CR}$ = complete response, $\mathrm{PR}=$ partial response, $\mathrm{AE}=$ adverse event, $\mathrm{TMZ}=$ temozolomide, $\mathrm{GBM}=$ glioblastoma, $\mathrm{RT}=$ radiation therapy, $\mathrm{HTN}$ = hypertension, $\mathrm{CHF}=$ congestive heart failure, $\mathrm{VTE}=$ venous thromboembolism, $\mathrm{PE}=$ pulmonary embolism, $\mathrm{ALT}$ = alanine aminotransferase, $\mathrm{AST}=$ aspartate aminotransferace, 
Chamberlain Study Description:

et al (2017)
Nivolumab for patients with progressive glioblastoma progressing on bevacizumab: a retrospective case series

Patient Population:

16 adult patients with progressive GBM were treated

Treatment Regimen:

Nivolumab was administered intravenously

to all patients at a dose of $3 \mathrm{mg} / \mathrm{kg}$ over $60 \mathrm{~min}$ once every

2 weeks. Low dose $(<2 \mathrm{mg} /$ day) concurrent dexamethasone was permitted for control of neurologic signs and

symptoms. A cycle of therapy was operationally defined as 28 days, during which nivolumab was administered on day 1 and 14 . Treatment was repeated every 14 days.
III

OS: median OS from nivolumab initiation $3.5 \mathrm{~m}$

PFS: $2 m$

Toxicity:

2 grade 3 events in 2 patients (fatigue and infection). No grade 4 or 5 events.

Authors'

Conclusions:

This small retrospective study suggests minimal benefit with nivolumab following disease progression on bevacizumab in patients with progressive GBM, a finding not previously documented in the literature, and begs the question of whether any current therapy warrants employment in this setting

Comments and Conclusions:

A small study without control arm warrants Class III designation.

Fenstermaker

Study Description:

III

Prospective phase I trial of subcutaneous

injections of SurVaxM (500 mug) in Montanide
Results:

Median progressionfree survival was 17.6 weeks, and

Abbreviations: $\mathrm{BEV}=$ bevacizumab, OS = overall survival, $\mathrm{PFS}=$ progression free survival, $\mathrm{PFS} 6=$ six month progression free survival, $\mathrm{RR}=$ response rate, $\mathrm{PD}=$ progressive disease, $\mathrm{SD}=$ stable disease, $\mathrm{CR}$ = complete response, $\mathrm{PR}=$ partial response, $\mathrm{AE}=$ adverse event, $\mathrm{TMZ}=$ temozolomide, $\mathrm{GBM}=$ glioblastoma, $\mathrm{RT}=$ radiation therapy, $\mathrm{HTN}$ = hypertension, $\mathrm{CHF}=$ congestive heart failure, $\mathrm{VTE}=$ venous thromboembolism, $\mathrm{PE}=$ pulmonary embolism, $\mathrm{ALT}$ = alanine aminotransferase, $\mathrm{AST}=$ aspartate aminotransferace, 


$\begin{array}{lll}\text { Author (year): } & \text { Description of study: } & \text { Data } \\ \text { Class: } & \text { Conclusions: }\end{array}$

ISA 51 with sargramostim (100 mug) at 2-week intervals

Patient Population:

9 pts with progressive GBM and survivin-positive, who had either HLA-A*02 or HLA-A*03 MHC class I allele-positivity.

\section{Treatment Regimen:}

Patients received SurVaxM (500 ug) in emulsion with Montanide ISA 51 with sargromostim (100 ug) every 2 weeks for a total of four doses per patient (prime-boost phase). Patients who survived 6 months without tumor progression or adverse events were eligible to receive additional vaccine every 3 months (booster phase).

Sakai et al (2015) median overall survival was 86.6 weeks from study entry with seven of nine patients surviving more than 12 months.

Toxicity:

No serious adverse events during the prime-boost phase. Six of 9 patients had at least one injection site reaction (grade 1 ), others with grade 1 or 2 fatigue, myalgias, lymphopenia and leukopenia. No vaccine-related grade 3 or 4 toxicity.

Authors'

Conclusions:

This first-in-human study demonstrated the safety, tolerability and immunogenicity of SurVaxM in patients with progressive malignant glioma following failure of standard therapy.

Comments and Conclusions:

A prospective phase 1 trial in nine patients without a control warrants class III designation.

III Results:

Median OS: 8.3 mos

Abbreviations: $\mathrm{BEV}$ = bevacizumab, OS = overall survival, $\mathrm{PFS}=$ progression free survival, $\mathrm{PFS} 6$ = six month progression free survival, $R R=$ response rate, $P D=$ progressive disease, $S D=$ stable disease, $C R$ = complete response, $\mathrm{PR}=$ partial response, $\mathrm{AE}=$ adverse event, $\mathrm{TMZ}=$ temozolomide, $\mathrm{GBM}=$ glioblastoma, $\mathrm{RT}=$ radiation therapy, $\mathrm{HTN}=$ hypertension, $\mathrm{CHF}$ = congestive heart failure, $\mathrm{VTE}=$ venous thromboembolism, $\mathrm{PE}=$ pulmonary embolism, $\mathrm{ALT}$ = alanine aminotransferase, $\mathrm{AST}=$ aspartate aminotransferace, 


\section{Data Conclusions:}

Class:

Prospective phase I study of Wilms' tumor 1 dendritic cell vaccine in progressive malignant glioma

\section{Patient Population:}

Adult patients with progressive malignant glioma (6 with glioblastoma)

Treatment Regimen:

$1 \times 10^{\wedge} 7$ to $2 \times 10^{\wedge} 7$ WT1-pulsed and/or autologous tumor lysate-pulsed DC were injected into the axillary region with OK-432 every two weeks for at least 5-7 sessions.

\section{Response to} treatment: Among the six patients with progressive glioblastoma (one converted from AA to GBM) one patient had stable disease after first course and the remainder had progressive disease. Overall response after final session was progressive disease in all patients.

Toxicity:

For the whole cohort, there were no grade 3 or higher toxicities. Common toxicities incldued erythema at the injection site, postvaccination fever and fatigue.

Authors'

Conclusions:

DC-based

immunotherapy targeting WT1 was safe and feasible for the management of advanced malignant gliomas.

Comments and Conclusions:

A phase I study in a small number of patients without controls warrants Class III designation.

Abbreviations: $\mathrm{BEV}=$ bevacizumab, $\mathrm{OS}=$ overall survival, $\mathrm{PFS}=$ progression free survival, $\mathrm{PFS} 6=$ six month progression free survival, $R R=$ response rate, $P D=$ progressive disease, $S D=$ stable disease, $C R$ = complete response, $\mathrm{PR}=$ partial response, $\mathrm{AE}$ = adverse event, $\mathrm{TMZ}=$ temozolomide, $\mathrm{GBM}=$ glioblastoma, $\mathrm{RT}=$ radiation therapy, $\mathrm{HTN}=$ hypertension, $\mathrm{CHF}=$ congestive heart failure, $\mathrm{VTE}=$ venous thromboembolism, $\mathrm{PE}=$ pulmonary embolism, $\mathrm{ALT}$ = alanine aminotransferase, $\mathrm{AST}=$ aspartate aminotransferace, 


$\begin{array}{lll}\text { Author (year): } & \text { Description of study: } & \text { Data } \\ \text { Class: } & \text { Conclusions: }\end{array}$

Schijns et al Study Description:

(2015)
III

Prospective Phase I trial of Gliovac vaccine in progressive GBM.

Patient Population:

9 adult patients with second recurrence of GBM after failure of surgery, TMZ chemoradiation and/or bevacizumab who qualify for surgical intervention to obtain an operable tumor mass.

\section{Treatment Regimen:}

Six cycles of five intradermally administered treatment doses of Gliovac. Each dose includes a cellular component and a lysate component prepared from freshly, surgically removed, GBM tumor tissue. Cell vial has $250 \mathrm{uL}$ of a suspension of $1 \times 10^{\wedge} 5-1 \times 10^{\wedge} 6$ irradiated DNFB-modified tumor cells and lysate vial has equivalent lysate of $a$ similar number of cells. Allogeneic A, B and C product doses are prepared from three different GBM donors, while autologous Gliovac $D$ dose is from the patient's own tumor. Gliovac treatment is administered with GM-CSF following 3 days of low dose cyclophosphamide. Six treatment cycles were repeated every 28 days.
Bloch et al (2014)
Results:

Median OS: not achieved over followup period, but 40 week OS was $77 \%$.

Response to treatment: Survival was improved in comparison to historical controls, with 40 week OS $77 \%$ and little toxicity.

Toxicity:

Two patients had grade 2 headaches, 4 had grade 2 local erythema at the injection site, other mild systemic reactions including self-limiting fever and chills.

\section{Authors'}

Conclusions:

The observed safety and promising clinical results of Gliovac led to approval for the development of a Phase Il clinical trial.

Comments and Conclusions:

A phase 1 trial in a small cohort of patients without control warrants Class III designation.

III

Results:

Abbreviations: $\mathrm{BEV}=$ bevacizumab, OS = overall survival, $\mathrm{PFS}=$ progression free survival, $\mathrm{PFS} 6=$ six month progression free survival, $R R=$ response rate, $P D=$ progressive disease, $S D=$ stable disease, $C R$ = complete response, $\mathrm{PR}=$ partial response, $\mathrm{AE}=$ adverse event, $\mathrm{TMZ}=$ temozolomide, $\mathrm{GBM}=$ glioblastoma, $\mathrm{RT}=$ radiation therapy, $\mathrm{HTN}$ = hypertension, $\mathrm{CHF}=$ congestive heart failure, $\mathrm{VTE}=$ venous thromboembolism, $\mathrm{PE}=$ pulmonary embolism, $\mathrm{ALT}$ = alanine aminotransferase, $\mathrm{AST}=$ aspartate aminotransferace, 


\section{Author (year): Description of study: \\ Data Conclusions: \\ Class:}

Single Arm Phase II trial, multi institution study on the safety and efficacy of HSPPC-96 vaccine in patients with progressive glioblastoma

Patient Population:

41 adult patients with progressive glioblastoma, Karnofsky of at least 70, resection of at least $90 \%$ of progressive tumor, and without disease progression at 4 weeks post operatively underwent vaccination with HSPPC-96

Treatment Regimen:

38 patients treated with at least 6 vaccinations of HSPPC-96, 3 received less than the protocol minimum of 4 and were excluded from efficacy population median PFS: 19.1w, 6m PFS 29.3\%

median OS: 42.6W, 6m OS: $90.2 \%, 12 \mathrm{~m}$ OS: $29.3 \%$

Toxicity:

1 patient with Grade III fatigue, no grade IV events or deaths associated with vaccine, 17 serious adverse events associated with surgical resection and consistent with known risks of surgery.

Authors'

Conclusions:

The findings of the current study are also comparable to the best outcomes reported with Bevacizumab. A proper comparison of the efficacy of

HSPPC-96

vaccination with bevacizumab would require equivalent

surgical resection in both groups. We believe the findings in the

current study support the value of a comparison between the

HSPPC-96 vaccine and bevacizumab in

Abbreviations: $\mathrm{BEV}=$ bevacizumab, OS = overall survival, $\mathrm{PFS}=$ progression free survival, $\mathrm{PFS} 6$ = six month progression free survival, $\mathrm{RR}=$ response rate, $\mathrm{PD}=$ progressive disease, $\mathrm{SD}=$ stable disease, $\mathrm{CR}$ = complete response, $\mathrm{PR}=$ partial response, $\mathrm{AE}=$ adverse event, $\mathrm{TMZ}=$ temozolomide, $\mathrm{GBM}=$ glioblastoma, $\mathrm{RT}=$ radiation therapy, $\mathrm{HTN}$ = hypertension, $\mathrm{CHF}=$ congestive heart failure, $\mathrm{VTE}=$ venous thromboembolism, $\mathrm{PE}=$ pulmonary embolism, $\mathrm{ALT}$ = alanine aminotransferase, $\mathrm{AST}=$ aspartate aminotransferace, 
Data Conclusions:

Class:
Schuessler et Study Description:

al (2014)
Prospective Phase I trial of autologous CMVspecific T-cell therapy for progressive GBM

Patient Population:

Nineteen adult patients with progressive GBM whow had positive CMV serology (four patients were withdrawn before venesection due to progressive disease, while insufficient CMVspecific $T$ cells were expanded from two patients due to low precursor frequency or poor cell viability, with a total of 10 patients completing a minimum of three infusions as required.

Treatment Regimen:

A minimum of three T-cell infusions consisting of 25 to $40 \times 10^{\wedge} 6$ autologous CMV-specific T cells in sterile saline were administered in 4 (+/- 2$)$ weeks intervals, coordinated with periods of chemotherapy to avoid unwanted side effects. surgically accessible

progressive tumors.

Comments and Conclusions:

Classified as Class III because, while it is a multicenter

prospective study, it is without a control group. This study and its conclusions have significant limitations, although promising, and this methodology warrants further research.

Results:

Median OS: of those who received at least one infusion was 403 days.

Response to
treatment: CMV-
specific
immunotherapy was
coincident with
disease stabilization
and prolonged PFS in
some patients. Four
of the 10 patients
who completed T-cell
therapy remained
progression free.
This includes one
patient disease free
four years after
infusion.
Toxicity:
The majority of
adverse events were
minor, with a single

Abbreviations: $\mathrm{BEV}=$ bevacizumab, $\mathrm{OS}=$ overall survival, $\mathrm{PFS}=$ progression free survival, $\mathrm{PFS} 6=\mathrm{six}$ month progression free survival, $R R=$ response rate, $P D=$ progressive disease, $S D=$ stable disease, $C R$ = complete response, $\mathrm{PR}=$ partial response, $\mathrm{AE}$ = adverse event, $\mathrm{TMZ}=$ temozolomide, $\mathrm{GBM}=$ glioblastoma, $\mathrm{RT}=$ radiation therapy, $\mathrm{HTN}$ = hypertension, $\mathrm{CHF}=$ congestive heart failure, $\mathrm{VTE}=$ venous thromboembolism, $\mathrm{PE}=$ pulmonary embolism, $\mathrm{ALT}$ = alanine aminotransferase, $\mathrm{AST}=$ aspartate aminotransferace, 
Data Conclusions: Class:

serious adverse event (seizure within 12 hourse of first T-cell infusion, without subsequent seizures with other infusions).

Authors'

Conclusions:

Adoptive immunotherapy of patients with progressive GBM with CMV-specific T cells is safe and may provide long-term clinical benefit.

Comments and Conclusions:

A nonrandomized, phase 1 trial without control in a small cohort warrants Class III designation.

Tanaka et al Study Description: (2013)
Prospective, nonrandomized trial of HUVEC vaccine therapy in progressive GBM.

Patient Population:

17 adult patients with progressive GBM (no limit on previous regimens or salvage treatments).

Treatment Regimen:

Human umbilical vein endothelial cells (HUVEC) were isolated from healthy donors at delivery, and cultured on $0.1 \%$ gelatin (w/v)-coated dishes in EC-SFM, then fixed with $0.025 \%$ glutaraldehyde (v/v) and stored at $-80 \mathrm{C}$ in single dose aliquots containing $5 \times 10^{\wedge} 7$ cells $/ \mathrm{mL}$ in physiological saline for injection. Patients received intradermal injections of $1.5 \mathrm{~mL}$ vaccine in the upper arm weekly during the first month, and every 2 weeks subsequently, until disease progression.
III

Results:

Response to treatment: Among the 17 patients with at least one dose of vaccine, one patient had a partial response, four had progressive disease, all others stable disease at first follow-up. Median PFS was 5.5 mos

Toxicity:

Delayed-type hypersensitivity skin reactions developed at the injection site in 14 of 17 patients. No

Abbreviations: $B E V$ = bevacizumab, OS = overall survival, PFS = progression free survival, PFS6 = six month progression free survival, $\mathrm{RR}=$ response rate, $\mathrm{PD}=$ progressive disease, $\mathrm{SD}=\mathrm{stable}$ disease, $\mathrm{CR}$ = complete response, $\mathrm{PR}=$ partial response, $\mathrm{AE}=$ adverse event, $\mathrm{TMZ}=$ temozolomide, $\mathrm{GBM}=$ glioblastoma, $\mathrm{RT}=$ radiation therapy, $\mathrm{HTN}$ = hypertension, $\mathrm{CHF}=$ congestive heart failure, $\mathrm{VTE}=$ venous thromboembolism, $\mathrm{PE}=$ pulmonary embolism, ALT = alanine aminotransferase, $\mathrm{AST}=$ aspartate aminotransferace, 
Data Conclusions:

Class:

other adverse events were noted from the vaccination.

Authors'

Conclusions:

HUVEC vaccine therapy is well tolerated with unlikely acquisition of resistance. However, radiological response was low (5.9\%) despite the median OS comparing favorably with other salvage therapies. More study is warranted.

Comments and Conclusions:

A prospective, nonrandomized trial without control in a small cohort warrants Class III designation.

Abbreviations: $\mathrm{BEV}=$ bevacizumab, OS = overall survival, $\mathrm{PFS}=$ progression free survival, $\mathrm{PFS} 6=$ six month progression free survival, $R R=$ response rate, $P D=$ progressive disease, $S D=$ stable disease, $C R$ = complete response, $\mathrm{PR}=$ partial response, $\mathrm{AE}$ = adverse event, $\mathrm{TMZ}=$ temozolomide, $\mathrm{GBM}=$ glioblastoma, $\mathrm{RT}=$ radiation therapy, $\mathrm{HTN}$ = hypertension, $\mathrm{CHF}=$ congestive heart failure, $\mathrm{VTE}=$ venous thromboembolism, $\mathrm{PE}=$ pulmonary embolism, $\mathrm{ALT}$ = alanine aminotransferase, $\mathrm{AST}=$ aspartate aminotransferace, 


\begin{tabular}{llll}
\hline Author (year): & Description of study: & Data & Conclusions: \\
& & Class:
\end{tabular}

Chang et al Study Description:

(2011)
Open label, Single arm phase I/II clinical trial investigating the adverse and therapeutic effects of a

postoperative autologous dendritic cell tumor vaccine in patients with

malignant glioma

Patient Population: 17 patients enrolled, 6 adult patients with progressive GBM

Treatment Regimen: After recovery from cytoreductive craniotomy, DC vaccines exposed to autologous glioma cells were given according to study's vaccine protocol
III

Results:

OS: $36 \mathrm{~m}$

Toxicity:

1 patient with Grade

III Lymphopenia,

Authors'

Conclusions:

Our results also suggest the possible benefit of our DCtumor vaccine preparation and treatment protocol for adjuvant therapy of

post-surgical residual GBM

Comments and Conclusions:

Classified as Class III due to its open label, nonrandomized, dose-escalation design without a control arm and small patient population.

III

Results: (2011)

Study Description:

Prospective, Phase I trial of HLA-A24 patients receiving ITK-1 peptide vaccine for progressive GBM

Patient Population:

12 adult patients with positive humoral responses to at least four of 14 HLA-A24-restricted candidate peptides (ITK-1) with progressive supratentorial GBM (multicenter, open-label, dose-escalation design)
Median OS: 10.5 mos

Response to treatment: following resist criteria, one patient had PR, seven had SD and four had PD

Toxicity:

Abbreviations: $\mathrm{BEV}=$ bevacizumab, $\mathrm{OS}=$ overall survival, $\mathrm{PFS}=$ progression free survival, $\mathrm{PFS} 6=\mathrm{six}$ month progression free survival, $R R=$ response rate, $P D=$ progressive disease, $S D=$ stable disease, $C R$ = complete response, $\mathrm{PR}=$ partial response, $\mathrm{AE}$ = adverse event, $\mathrm{TMZ}=$ temozolomide, $\mathrm{GBM}=$ glioblastoma, $\mathrm{RT}=$ radiation therapy, $\mathrm{HTN}$ = hypertension, $\mathrm{CHF}=$ congestive heart failure, $\mathrm{VTE}=$ venous thromboembolism, $\mathrm{PE}=$ pulmonary embolism, $\mathrm{ALT}$ = alanine aminotransferase, $\mathrm{AST}=$ aspartate aminotransferace, 


\begin{tabular}{|c|c|c|c|}
\hline Author (year): & Description of study: & $\begin{array}{l}\text { Data } \\
\text { Class: }\end{array}$ & Conclusions: \\
\hline & Treatment Regimen: & & \multirow[b]{2}{*}{$\begin{array}{l}\text { Grade } 1 \text { or } 2 \text { skin } \\
\text { inflammatory } \\
\text { reactions at injection } \\
\text { sites occurred in all } \\
\text { patients with no } \\
\text { grade } 3 \text { SAE reported. } \\
\text { However, the highest } \\
\text { dose escalation of } 5 \\
\text { mg/peptide was } \\
\text { skipped because of } \\
\text { injection site } \\
\text { reactions at this dose } \\
\text { noted in another } \\
\text { advanced prostate } \\
\text { cancer trial } \\
\text { performed } \\
\text { simultaneously. }\end{array}$} \\
\hline & \multirow[t]{5}{*}{$\begin{array}{l}100+\text { genes encoding cancer antigens } \\
\text { (nonmutated proteins) involved in cellular } \\
\text { proliferation but not frequently expressed in } \\
\text { normal cells were identified, with } 14 \text { peptides } \\
\text { selected from this cohort for the ITK- }-1 \text { vaccine. Of } \\
\text { these, the four peptides showing the highest IgG } \\
\text { titers were selected for vaccination in each } \\
\text { patient. Patients then received peptides weekly for } \\
\text { up to six times by subcutaneous injection into the } \\
\text { upper back region at three different dose settings } \\
\text { ( } 1,3 \text {, and } 5 \mathrm{mg} / \text { peptide). Dose escalation was } \\
\text { allowed after evaluation of safety. Each cycle } \\
\text { lasted six weeks, with cycles repeated if no } \\
\text { serious adverse events until disease progression. }\end{array}$} & & \\
\hline & & & $\begin{array}{l}\text { Authors' } \\
\text { Conclusions: }\end{array}$ \\
\hline & & & $\begin{array}{l}\text { Personalized } \\
\text { vaccination with ITK- } \\
1 \text { peptide in patients } \\
\text { who are HLA-A24 } \\
\text { positive with GBM } \\
\text { may be worthwhile } \\
\text { for future clinical } \\
\text { trials due to its safety } \\
\text { and potential to } \\
\text { boost the immune } \\
\text { system. }\end{array}$ \\
\hline & & & $\begin{array}{l}\text { Comments and } \\
\text { Conclusions: }\end{array}$ \\
\hline & & & $\begin{array}{l}\text { A small, single-arm } \\
\text { phase } 1 \text { study } \\
\text { warrants Class III } \\
\text { designation. }\end{array}$ \\
\hline
\end{tabular}

Abbreviations: $\mathrm{BEV}=$ bevacizumab, OS = overall survival, $\mathrm{PFS}=$ progression free survival, $\mathrm{PFS} 6=$ six month progression free survival, $\mathrm{RR}=$ response rate, $\mathrm{PD}=$ progressive disease, $\mathrm{SD}=$ stable disease, $\mathrm{CR}$ = complete response, $\mathrm{PR}=$ partial response, $\mathrm{AE}=$ adverse event, $\mathrm{TMZ}=$ temozolomide, $\mathrm{GBM}=$ glioblastoma, $\mathrm{RT}=$ radiation therapy, $\mathrm{HTN}$ = hypertension, $\mathrm{CHF}=$ congestive heart failure, $\mathrm{VTE}=$ venous thromboembolism, $\mathrm{PE}=$ pulmonary embolism, $\mathrm{ALT}$ = alanine aminotransferase, $\mathrm{AST}=$ aspartate aminotransferace, 


\begin{tabular}{|c|c|c|c|}
\hline Author (year): & Description of study: & $\begin{array}{l}\text { Data } \\
\text { Class: }\end{array}$ & Conclusions: \\
\hline $\begin{array}{l}\text { Clavreul et al } \\
(2010)\end{array}$ & $\begin{array}{l}\text { Study Description: } \\
\text { open, non-randomized, phase I study to evaluate } \\
\text { the safety and feasibility of vaccination with } \\
\text { Autologous tumor cells (ATC) and infusion of GM- } \\
\text { CSF by a programmable pump in the treatment of } \\
\text { progressive malignant gliomas } \\
\text { Patient Population: } \\
6 \text { adult patients with progressive glioblastoma, } \\
\text { isolated from } 9 \text { patients with progressive high- } \\
\text { grade glioma } \\
\text { Treatment Regimen: Patients underwent surgical } \\
\text { resection at recurrence, tumor collected at surgery } \\
\text { was then expanded in vitro, irradiated at } 45 \text { Gy, } \\
\text { and then frozen. The cells were then thawed and } \\
\text { administered between } 2.0 \text { and } 5.0 \text { x } 10^{\wedge} 6 \text { ATC in } \\
600 \text { uL of physiological serum subcutaneously. } \\
\text { Recombinant GM-CSF was then infused at the } \\
\text { site of cell inoculation. Two vaccine protocols } \\
\text { included } 1 \text { ) four SC vaccinations with ATC every } 7 \\
\text { days in the abdomen and continuous infusion of } \\
\text { GM-CSF (10 ug/ } 24 \text { hours) for } 28 \text { days or } 2 \text { ) four } \\
\text { SC vaccinations with ATC every } 21 \text { days close to } \\
\text { cervical lymph nodes with GM-CSF infusion for } 3 \\
\text { days before and } 14 \text { days after each vaccination. }\end{array}$ & III & $\begin{array}{l}\text { Results: } \\
\text { OS: } 8.6 \mathrm{~m} \\
\text { Authors' } \\
\text { Conclusions: } \\
\text { This clinical trial } \\
\text { shows that induction } \\
\text { of a peripheral } \\
\text { antitumor immune } \\
\text { response is possible } \\
\text { in glioma patients } \\
\text { but not sufficient to } \\
\text { preclude disease } \\
\text { progression. } \\
\text { Comments and } \\
\text { Conclusions: } \\
\text { Classified as Class III } \\
\text { due to its open label, } \\
\text { nonrandomized, } \\
\text { design without a } \\
\text { control arm and } \\
\text { small patient } \\
\text { population. }\end{array}$ \\
\hline
\end{tabular}

Abbreviations: $\mathrm{BEV}=$ bevacizumab, OS = overall survival, $\mathrm{PFS}=$ progression free survival, $\mathrm{PFS} 6=$ six month progression free survival, $R R=$ response rate, $P D=$ progressive disease, $S D=$ stable disease, $C R$ = complete response, $\mathrm{PR}=$ partial response, $\mathrm{AE}=$ adverse event, $\mathrm{TMZ}=$ temozolomide, $\mathrm{GBM}=$ glioblastoma, $\mathrm{RT}=$ radiation therapy, $\mathrm{HTN}$ = hypertension, $\mathrm{CHF}=$ congestive heart failure, $\mathrm{VTE}=$ venous thromboembolism, $\mathrm{PE}=$ pulmonary embolism, $\mathrm{ALT}$ = alanine aminotransferase, $\mathrm{AST}=$ aspartate aminotransferace, 


\begin{tabular}{|c|c|c|c|}
\hline Author (year): & Description of study: & $\begin{array}{l}\text { Data } \\
\text { Class: }\end{array}$ & Conclusions: \\
\hline \multirow{9}{*}{$\begin{array}{l}\text { Hau et al } \\
\text { (2007) }\end{array}$} & Study Description: & III & Results: \\
\hline & $\begin{array}{l}\text { Prospective phase I/trial of treatment with TGF- } \\
\text { beta2 inhibitor AP } 12009 \text { employing patient- } \\
\text { derived malignant glioma cells as well as } \\
\text { peripheral blood mononuclear cells (PBMCs) }\end{array}$ & & $\begin{array}{l}\text { Prolonged survival } \\
\text { compared to } \\
\text { literature data, } \\
\text { although not }\end{array}$ \\
\hline & Patient Population: & & $\begin{array}{l}\text { an efficacy } \\
\text { evaluation. }\end{array}$ \\
\hline & 24 HGG pts. & & Toxicity: \\
\hline & $\begin{array}{l}\text { Treatment Regimen: Perforated part of catheter } \\
\text { was inserted into the largest, solid, contrast } \\
\text { enhancing area of the tumor, avoiding ventricles, } \\
\text { cysts, prior surgical resection cavities, blood } \\
\text { vessels and eloquent brain areas. The first two } \\
\text { patients, the catheter was passed through the } \\
\text { skin, but was later modified to allow multiple } \\
\text { cycle application. AP } 12009 \text { was infused over the } \\
\text { implanted port system continuously for } 4 \text { days or } \\
7 \text { days depending on treatment group. }\end{array}$ & & $\begin{array}{l}\text { No infections related } \\
\text { to the implanted } \\
\text { catheter, and no } \\
\text { treatment-related } \\
\text { deaths or life- } \\
\text { threatening toxicity. } 7 \\
\text { of } 24 \text { patients } \\
\text { experienced had an } \\
\text { AE, with } 2 \text { Grade } 3 \\
\text { and no Grade } 4 \text {. }\end{array}$ \\
\hline & & & $\begin{array}{l}\text { Authors' } \\
\text { Conclusions: }\end{array}$ \\
\hline & & & $\begin{array}{l}\text { The major endpoints } \\
\text { of safety and } \\
\text { tolerability have been } \\
\text { achieved. }\end{array}$ \\
\hline & & & $\begin{array}{l}\text { Comments and } \\
\text { Conclusions: }\end{array}$ \\
\hline & & & $\begin{array}{l}\text { This was not an } \\
\text { efficacy trial, and as } \\
\text { a phase } 1 \text { trial in a } \\
\text { small cohort of } \\
\text { nonrandomized } \\
\text { patients, it was } \\
\text { designated as class } \\
\text { III. }\end{array}$ \\
\hline
\end{tabular}

Abbreviations: $\mathrm{BEV}=$ bevacizumab, OS = overall survival, $\mathrm{PFS}=$ progression free survival, $\mathrm{PFS} 6=$ six month progression free survival, $\mathrm{RR}=$ response rate, $\mathrm{PD}=$ progressive disease, $\mathrm{SD}=$ stable disease, $\mathrm{CR}$ = complete response, $\mathrm{PR}=$ partial response, $\mathrm{AE}=$ adverse event, $\mathrm{TMZ}=$ temozolomide, $\mathrm{GBM}=$ glioblastoma, $\mathrm{RT}=$ radiation therapy, $\mathrm{HTN}$ = hypertension, $\mathrm{CHF}=$ congestive heart failure, $\mathrm{VTE}=$ venous thromboembolism, $\mathrm{PE}=$ pulmonary embolism, $\mathrm{ALT}$ = alanine aminotransferase, $\mathrm{AST}=$ aspartate aminotransferace, 


$\begin{array}{lll}\text { Author (year): } & \text { Description of study: } & \text { Data } \\ & \text { Class: } & \text { Conclusions: }\end{array}$

Carpentier et Study Description:

al (2006)
Phase 1 trial was designed as an open-label, nonrandomized study.

Patient Population:

24 patients enrolled, 9 at first recurrence, 8 at second recurrence, 7 at third recurrence

Treatment Regimen:

groups of 3-6 patients were treated with escalating doses of $\mathrm{CpG}-28$
III

\section{Results:}

Median Survival:

$7.2 \mathrm{~m}$

PFS-6: $4.5 \%$, 1yS: $28 \%$

Toxicity:

1 dose limiting toxicity, 4 neurologic deterioration, 7 Grade III lymphopenia, 2 Grade III ALT elevation, 1 Grade III Hyponatremia

Authors'

Conclusions:

this study demonstrated that local treatment with CpG ODNs in patients with progressive glioblastoma is feasible and well tolerated at doses up to $20 \mathrm{mg}$.

Comments and Conclusions:

Classified as Class III due to its open label, nonrandomized, dose-escalation design without a control arm and small patient population.

III

Results:

(2006)

Study Description:

Prospective phase I trial or whole-cell vaccine comprising autologous tumor cells genetically
The overall median survival was 68 weeks. Median

Abbreviations: $\mathrm{BEV}=$ bevacizumab, $\mathrm{OS}=$ overall survival, $\mathrm{PFS}=$ progression free survival, $\mathrm{PFS} 6=\mathrm{six}$ month progression free survival, $\mathrm{RR}=$ response rate, $\mathrm{PD}=$ progressive disease, $\mathrm{SD}=$ stable disease, $\mathrm{CR}$ = complete response, $\mathrm{PR}=$ partial response, $\mathrm{AE}=$ adverse event, $\mathrm{TMZ}=$ temozolomide, $\mathrm{GBM}=$ glioblastoma, $\mathrm{RT}=$ radiation therapy, $\mathrm{HTN}$ = hypertension, $\mathrm{CHF}=$ congestive heart failure, $\mathrm{VTE}=$ venous thromboembolism, $\mathrm{PE}=$ pulmonary embolism, $\mathrm{ALT}$ = alanine aminotransferase, $\mathrm{AST}=$ aspartate aminotransferace, 


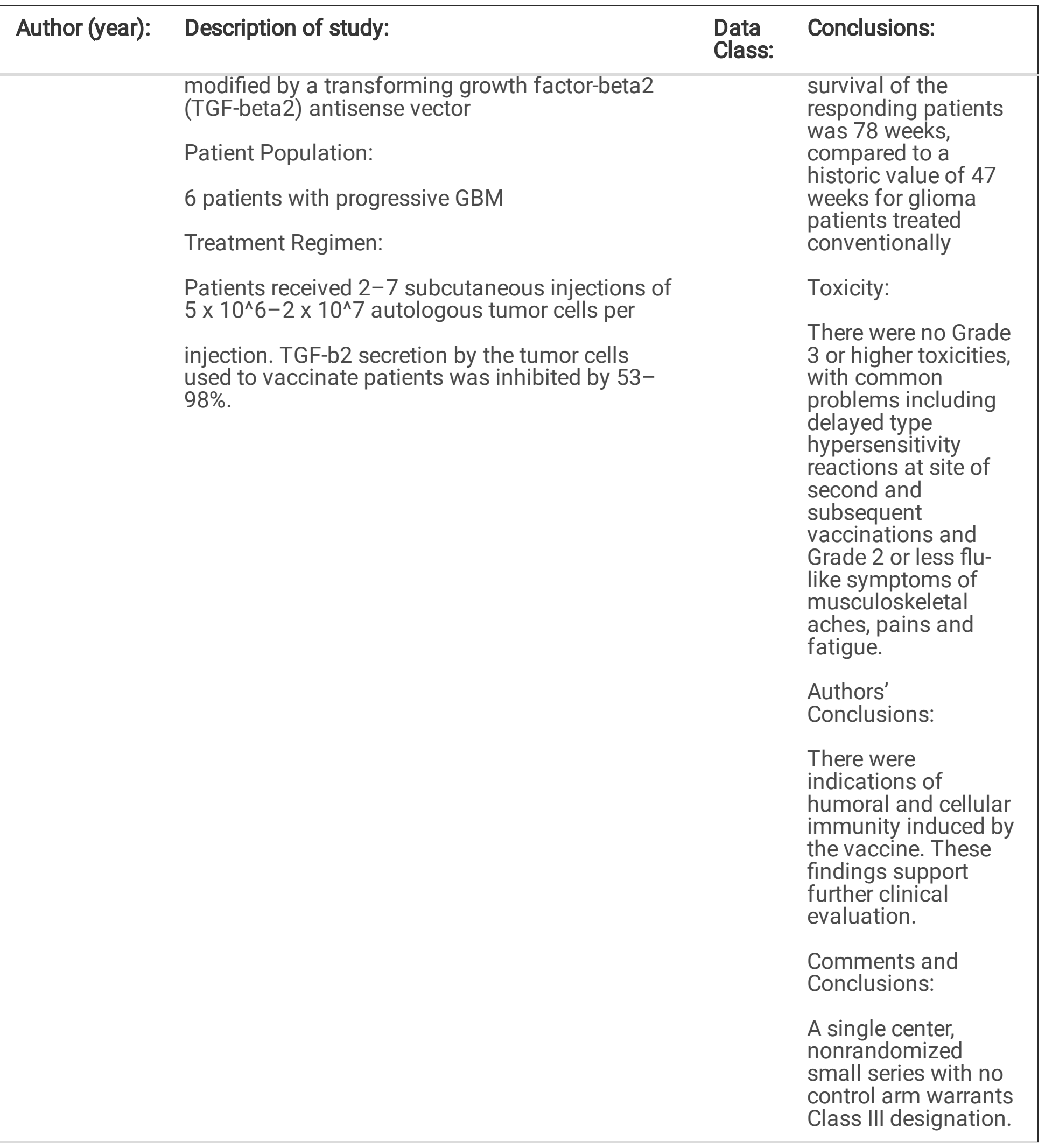

Abbreviations: $\mathrm{BEV}$ = bevacizumab, OS = overall survival, $\mathrm{PFS}=$ progression free survival, $\mathrm{PFS} 6$ = six month progression free survival, $\mathrm{RR}=$ response rate, $\mathrm{PD}=$ progressive disease, $\mathrm{SD}=$ stable disease, $\mathrm{CR}$ = complete response, $\mathrm{PR}=$ partial response, $\mathrm{AE}=$ adverse event, $\mathrm{TMZ}=$ temozolomide, $\mathrm{GBM}=$ glioblastoma, $\mathrm{RT}=$ radiation therapy, $\mathrm{HTN}$ = hypertension, $\mathrm{CHF}=$ congestive heart failure, $\mathrm{VTE}=$ venous thromboembolism, $\mathrm{PE}=$ pulmonary embolism, $\mathrm{ALT}$ = alanine aminotransferase, $\mathrm{AST}=$ aspartate aminotransferace, 


\begin{tabular}{|c|c|c|c|}
\hline Author (year): & Description of study: & $\begin{array}{l}\text { Data } \\
\text { Class: }\end{array}$ & Conclusions: \\
\hline \multirow{11}{*}{$\begin{array}{l}\text { Yamanaka et } \\
\text { al (2005) }\end{array}$} & Study Description: & III & Results: \\
\hline & $\begin{array}{l}\text { Phase } 1 / \text { II trial of dendritic cell therapy in } \\
\text { malignant glioma }\end{array}$ & & $\begin{array}{l}\text { Median OS: } 464.5 \\
\text { days (15.5 mos) }\end{array}$ \\
\hline & Patient Population: & & Response to \\
\hline & 24 adult patients ( 18 with progressive GBM). & & GBM patients, 6 had \\
\hline & Treatment Regimen: & & response, 1 had PR, \\
\hline & $\begin{array}{l}\text { The patient's peripheral blood dendritic cells were } \\
\text { generated with GM-CSF plus IL } 4 \text { with or without }\end{array}$ & & Toxicity: \\
\hline & $\begin{array}{l}\text { Dendritic cells were injected intradermally or both } \\
\text { intratumorally and intradermally every three } \\
\text { weeks. }\end{array}$ & & $\begin{array}{l}\text { There were no } \\
\text { serious adverse } \\
\text { effects and no } \\
\text { clinical or } \\
\text { radiological evidence } \\
\text { of autoimmune } \\
\text { reactions in any } \\
\text { patients. There was } \\
\text { mild erythema at the } \\
\text { cervical injection site } \\
\text { in seven cases, and a } \\
\text { mild headache } \\
\text { lasting a few days in } \\
\text { one patient. }\end{array}$ \\
\hline & & & $\begin{array}{l}\text { Authors' } \\
\text { Conclusions: }\end{array}$ \\
\hline & & & $\begin{array}{l}\text { Dendritic cell } \\
\text { vaccination of } \\
\text { patients with glioma } \\
\text { seems to be safe and } \\
\text { not associated with } \\
\text { autoimmunity. }\end{array}$ \\
\hline & & & $\begin{array}{l}\text { Comments and } \\
\text { Conclusions: }\end{array}$ \\
\hline & & & $\begin{array}{l}\text { A phase I/II trial in a } \\
\text { small cohort of } \\
\text { patients with no } \\
\text { control warrants } \\
\text { Class III designation. }\end{array}$ \\
\hline
\end{tabular}

Abbreviations: $\mathrm{BEV}=$ bevacizumab, OS = overall survival, $\mathrm{PFS}=$ progression free survival, $\mathrm{PFS} 6=$ six month progression free survival, $\mathrm{RR}=$ response rate, $\mathrm{PD}=$ progressive disease, $\mathrm{SD}=$ stable disease, $\mathrm{CR}$ = complete response, $\mathrm{PR}=$ partial response, $\mathrm{AE}=$ adverse event, $\mathrm{TMZ}=$ temozolomide, $\mathrm{GBM}=$ glioblastoma, $\mathrm{RT}=$ radiation therapy, $\mathrm{HTN}$ = hypertension, $\mathrm{CHF}=$ congestive heart failure, $\mathrm{VTE}=$ venous thromboembolism, $\mathrm{PE}=$ pulmonary embolism, $\mathrm{ALT}$ = alanine aminotransferase, $\mathrm{AST}=$ aspartate aminotransferace, 


\begin{tabular}{|c|c|c|c|}
\hline Author (year): & Description of study: & $\begin{array}{l}\text { Data } \\
\text { Class: }\end{array}$ & Conclusions: \\
\hline $\begin{array}{l}\text { Dillman et al } \\
(2004)\end{array}$ & $\begin{array}{l}\text { Study Description: } \\
\text { Prospective phase I trial of intralesional } \\
\text { lymphokine-activated killer (LAK) cells following } \\
\text { surgery } \\
\text { Patient Population: } \\
40 \text { pts with progressive GBM } \\
\text { Treatment Regimen: } \\
\text { At time of surgery, patients received autologous } \\
\text { LAK cells into the tumor cavity. }\end{array}$ & III & $\begin{array}{l}\text { Results: } \\
\text { At a median follow- } \\
\text { up of } 2.3 \text { years, } \\
\text { median survival post- } \\
\text { LAK was } 9.0 \text { months; } \\
\text { 1-year survival was } \\
34 \% \text {. } \\
\text { Toxicity: } \\
\text { One patient } \\
\text { developed a } \\
\text { superficial surgical } \\
\text { wound infection } \\
\text { resolving with } \\
\text { antibiotics, one } \\
\text { patient who died } \\
\text { within } 1 \text { mo of } \\
\text { treatment from } \\
\text { status epilepticus. } \\
\text { Authors' } \\
\text { Conclusions: } \\
\text { Treatment is safe } \\
\text { and feasible. Median } \\
\text { survival rates are } \\
\text { higher than reported } \\
\text { in most published } \\
\text { series of those who } \\
\text { undergo reoperation } \\
\text { for progressive GBM. } \\
\text { Comments and } \\
\text { Conclusions: } \\
\text { This study was Class } \\
\text { Ill as a prospective } \\
\text { phase I trial without } \\
\text { control in a small } \\
\text { cohort. }\end{array}$ \\
\hline
\end{tabular}

Abbreviations: $\mathrm{BEV}=$ bevacizumab, OS = overall survival, $\mathrm{PFS}=$ progression free survival, $\mathrm{PFS} 6=$ six month progression free survival, $\mathrm{RR}=$ response rate, $\mathrm{PD}=$ progressive disease, $\mathrm{SD}=$ stable disease, $\mathrm{CR}$ = complete response, $\mathrm{PR}=$ partial response, $\mathrm{AE}=$ adverse event, $\mathrm{TMZ}=$ temozolomide, $\mathrm{GBM}=$ glioblastoma, $\mathrm{RT}=$ radiation therapy, $\mathrm{HTN}$ = hypertension, $\mathrm{CHF}=$ congestive heart failure, $\mathrm{VTE}=$ venous thromboembolism, $\mathrm{PE}=$ pulmonary embolism, $\mathrm{ALT}$ = alanine aminotransferase, $\mathrm{AST}=$ aspartate aminotransferace, 


\begin{tabular}{|c|c|c|c|}
\hline Author (year): & Description of study: & $\begin{array}{l}\text { Data } \\
\text { Class: }\end{array}$ & Conclusions: \\
\hline \multirow{10}{*}{$\begin{array}{l}\text { Tsuboi et al } \\
\text { (2003) }\end{array}$} & Study Description: & III & Results: \\
\hline & $\begin{array}{l}\text { Phase I trial of ex vivo expanded autologous } \\
\text { tumor-specific T lymphocytes (ATTLs) for } \\
\text { progressive malignant glioma }\end{array}$ & & $\begin{array}{l}\text { Median OS of the } 7 \\
\text { patients with GBM: } 4 \\
\text { mos }\end{array}$ \\
\hline & Patient Population: & & \multirow{3}{*}{$\begin{array}{l}\text { Response to } \\
\text { treatment: There } \\
\text { were } 3 \text { cases of PR, } 3 \\
\text { SD and one PD of the } \\
7 \text { patients with } \\
\text { glioblastoma. }\end{array}$} \\
\hline & $\begin{array}{l}7 \text { adult patients with progressive glioblastoma } \\
\text { were included in the cohort. }\end{array}$ & & \\
\hline & Treatment Regimen: & & \\
\hline & \multirow{5}{*}{$\begin{array}{l}\text { Target tumor tissue taken at first operation were } \\
\text { submitted for routine primary culture. } 3 \text { weeks } \\
\text { from separation of PBMC to induction of ATTLs } \\
\text { was necessary, followed by once weekly } \\
\text { injections of ATTLs in a } 2 \text {-mL suspension via } \\
\text { Ommaya reservoir into the cavity created by the } \\
\text { inital surgery (intrathecal in one case). }\end{array}$} & & $\begin{array}{l}\text { Toxicity: } \\
\text { eported as "minor } \\
\text { side effects" without } \\
\text { further explanation. }\end{array}$ \\
\hline & & & $\begin{array}{l}\text { Authors' } \\
\text { Conclusions: }\end{array}$ \\
\hline & & & $\begin{array}{l}\text { Results suggest that } \\
\text { local administration } \\
\text { of AATLs is effective } \\
\text { in progressive } \\
\text { malignant gliomas, } \\
\text { although its } \\
\text { antitumor effect may } \\
\text { be temporary. }\end{array}$ \\
\hline & & & $\begin{array}{l}\text { Comments and } \\
\text { Conclusions: }\end{array}$ \\
\hline & & & $\begin{array}{l}\text { A phase } 1 \text { trial in a } \\
\text { small cohort without } \\
\text { controls warrants } \\
\text { Class III designation. }\end{array}$ \\
\hline
\end{tabular}

Abbreviations: $\mathrm{BEV}=$ bevacizumab, OS = overall survival, $\mathrm{PFS}=$ progression free survival, $\mathrm{PFS} 6=$ six month progression free survival, $\mathrm{RR}=$ response rate, $\mathrm{PD}=$ progressive disease, $\mathrm{SD}=$ stable disease, $\mathrm{CR}$ = complete response, $\mathrm{PR}=$ partial response, $\mathrm{AE}=$ adverse event, $\mathrm{TMZ}=$ temozolomide, $\mathrm{GBM}=$ glioblastoma, $\mathrm{RT}=$ radiation therapy, $\mathrm{HTN}$ = hypertension, $\mathrm{CHF}=$ congestive heart failure, $\mathrm{VTE}=$ venous thromboembolism, $\mathrm{PE}=$ pulmonary embolism, $\mathrm{ALT}$ = alanine aminotransferase, $\mathrm{AST}=$ aspartate aminotransferace, 


$\begin{array}{lll}\text { Author (year): } & \text { Description of study: } & \text { Data } \\ & \text { Class: } & \text { Conclusions: }\end{array}$

Plautz et al Study Description:

(1998)
Prospective phase I trial of systemic adoptive immunotherapy

Patient Population:

Adult patients $(n=10)$ with grade III or IV malignant astrocytoma and good performance status and no evidence of immunocompromise.

Treatment Regimen: Irradiated tumor cells (17-56 $\times 10^{\wedge} 6$ tumor cells) suspended in $0.6 \mathrm{~mL}$ phosphate-buffered saline containing $250 \mathrm{ug}$ granulocyte macrophage-colony stimulating factor were injected intradermally on the anterior upper thigh bilaterally and GM-CSF (125 ug) was injected intradermally into each inoculation site daily for an additional three days. Inguinal lymph nodes draining the vaccine site were surgically removed 7 days after vaccination, T cells were extracted and activated, and then reinjected IV two days after oral cyclophosphamide (10 $\mathrm{mg} / \mathrm{kg}$ ).
III

\section{Results:}

Median OS: 11.3 mos

Response to treatment: Among the seven patients with progressive glioblastoma, there were two partial responses (one 7 mos, one over 13 mos) with the remaining patients having progressive disease.

Toxicity:

There were no Grade 3 or 4 toxicities. Among the ten patients studied, there were 2 Grade I toxicities and 9 Grade II toxicities.

\section{Authors'}

Conclusions:

These clinical observations warrant further trials to determine whether this approach can provide therapeutic benefits and improve survival.

Comments and Conclusions:

A phase I trial in 10 patients without control warrants Class III designation.

Abbreviations: $\mathrm{BEV}=$ bevacizumab, OS = overall survival, $\mathrm{PFS}=$ progression free survival, $\mathrm{PFS} 6=$ six month progression free survival, $\mathrm{RR}=$ response rate, $\mathrm{PD}=$ progressive disease, $\mathrm{SD}=$ stable disease, $\mathrm{CR}$ $=$ complete response, $\mathrm{PR}=$ partial response, $\mathrm{AE}=$ adverse event, $\mathrm{TMZ}=$ temozolomide, $\mathrm{GBM}=$ glioblastoma, $\mathrm{RT}=$ radiation therapy, $\mathrm{HTN}$ = hypertension, $\mathrm{CHF}=$ congestive heart failure, $\mathrm{VTE}=$ venous thromboembolism, $\mathrm{PE}=$ pulmonary embolism, ALT = alanine aminotransferase, $\mathrm{AST}=$ aspartate aminotransferace, 
Ahmed et al performed a phase I open label dose escalation trial using HER2-specific CAR-T cells in 17 total patients, 10 of which were adult patients. Results showed PFS of 3.5 months and mOS 11.1 months after infusion, 24.5 months after initial diagnosis. They concluded the HER2-CAR virus specific T cells (VSTs) are safe and may portend a clinical benefit.[85] In another specific T-Cell study, Schuessler et al reported on autologous CMV specific T cell administration in a study including 10 patients with complete data. Median OS of those with at least one infusion was 13.4 months and concluded the therapy was safe with a potential long-term clinical benefit.[105] Tsuboi et al studied autologous tumor specific Tlymphocytes (ATTLs) and suggested efficacy however with a potentially only temporary antitumor effect. [110] As phase I trials with small patient populations, these were all designated Class III.

\section{Vaccines}

Two studies included revolved around the use of dendritic cell (DC) vaccination. Chang et al

prospectively investigated post-operative administration of a dendritic cell autologous tumor vaccine in 6 adult progressive glioblastoma patients. Median OS was 36 months. The results here suggest a potential benefit with this vaccine for adjuvant therapy after repeat resection, but as it was only in a small series of patients this was designated Class III evidence.[89] Sakai et al's Wilms' Tumor DC vaccine in 6 cases resulted in a mOS of 8.3 months and was deemed safe, but no conclusion was made on efficacy in this Class III designated phase I trial.[102] Yamanaka et al evaluated a DC vaccine using peripheral blood dendritic cells generated with GMCSF and interleukin-4 (IL4) and pulsed with autologous tumor lysate in 24 patients. They were then vaccinated intratumorally, or both intratumorally and intradermally. Median OS was 15.5 months and the authors determined the vaccination trial proved safety in this Class III designated phase I trial.[111]

Another group of vaccination trials utilized autologous tissue and tumors to generate specific, individualized vaccinations. Fakhrai et al studied a whole-cell vaccine with autologous tumor cells modified with TGFb2 in 6 patients. Median OS was 15.9 months, and of those with an immune response having a median OS of 18.2 months. The comparison cited a historic mOS value of 11 months for conventional treatment, concluding that the humoral and cellular immunity inductions support further evaluation.[94] This was designated Class III as a small, nonrandomized series. Plautz et al studied systemic adoptive therapy in 10 patients vaccinated with irradiated tumor cells. Median OS was 11.3 months and there was limited data which didn't provide evidence for a clinical benefit.[100] This data was designated Class III. Schijns et al used Gliovac in 9 patients, found a 40 week OS of $77 \%$, and received approval for development of a phase II clinical trial.[104]

Shibao et al prospectively studied a vaccine targeting angiogenesis factors in 9 progressive glioblastoma patients. There was limited outcome data included, with two patients achieving SD and six PD. The authors reported a preliminary sense of efficacy and safety. As a small series phase I trial, this is class III data.[106] 
Tanaka et al studied 17 adult patients receiving human umbilical vein endothelial cells. PFS was 5.5 months and authors concluded that although the vaccine had a low radiologic response rate, there was a favorable mOS compared to historical series for patients receiving salvage therapy after a varying number of previous lines of treatment through multiple recurrences.[107] This study warranted Class III designation.

Several peptide vaccination studies were also included. Bloch et al achieved a PFS of 4.5 months, PFS6 $29.3 \%$, mOS 9.9 months with HSPPC-96. They concluded the findings were comparable to the best outcomes with BEV, however they did not have a direct comparison and data was designated Class III.[86] Fenstermaker et al performed a phase I trial with SurVaxM in specific HLA subtypes. PFS was 4.1 months and mOS was 20.2 months with 7 patients surviving beyond 12 months, concluding the vaccine was safe and induced an immune response in progressive GBM patients after failure of standard therapy.[95] This was designated Class III for small sample size and a lack of a control group. Teresaki et al used individualized peptide vaccinations, achieving a mOS 10.5 months with seven patients showing stability of disease. Authors determined the vaccinations may have potential immune system boosting effects and could be worthy of further evaluation.[108] Tsuboi et al evaluated the Wilms tumor 1 (WT1) peptide vaccination in 9 progressive glioblastoma patients that completed the study. Median OS was 5.8 months and the authors determined this was a safe treatment regimen, but did not comment on efficacy.[109] All peptide vaccination studies were given Class III designation.

In the only Class I designated study in vaccine trials, and imumunotherapy, Narita et al prospectively evaluated 88 progressive glioblastoma with HLA-A24 positive patients given personalized peptide vaccines. Median OS was 8.4 months and the trial met neither the primary endpoints or secondary endpoints of OS, 1 year survival rate, antitumor responses, PFS, or PFS6, thus deeming the treatment of no significant benefit.[99]

\section{Immune Checkpoint Inhibitors}

Cloughesy et al's randomized pilot study of pembrolizumab (inhibitor of PD-1) evaluated 35 patients with surgically resectable progressive glioblastoma. Sixteen patients underwent neoadjujvant and adjuvant treatment while 19 patients received adjuvant therapy only. Median OS in the neoadjuvant group was 13.7 months and 7.5 months in the adjuvant group. Median PFS- 6 was 3.3 months in neoadjuvant, 2.4 months in the adjuvant group. The authors concluded PD-1 monoclonal blockade showed a significant OS and PFS benefit in the neoadjuvant group.[91] These data were deemed Class III since, despite being a multi-institutional, randomized design with a large patient population, it was pilot by design. Lukas et al studied atezolizumab, an anti-PDL1 agent, in 16 patients and found the drug to be well tolerated with mOS of 4.2 months, but did not comment on efficacy.[97] This was designated Class III as a doseescalation trial. In another class III study, Reiss et al found that heavily pretreated patients with high grade gliomas had low response rates to pembrolizumab.[101]

Three studies utilized nivolumab. Chamberlain et al's study of nivolumab, an immune checkpoint inhibitor targeting PD-1, was evaluated retrospectively after progression on BEV. They found mOS from treatment

Page 112/133 
initiation was 3.5 months with PFS 2 months, concluding there was minimal benefit with nivolumab after disease progression on BEV.[88] Schalper et al also studied nivolumab in resectable glioblastoma as both neoadjuvant and adjuvant therapy, finding no obvious benefit.[103] Mantica et al reviewed nivolumab and found the treatment was safe and a small subset of patients experienced disease stabilization.[98] All of these studies were considered Class III as two were retrospective and one was a small series without a control.

\section{Other Immunotherapy}

Clavreul et al's Phase I non-randomized study of Autologous Tumor Cells (ATC) with GM-CSF by subcutaneous programmable pump delivery in 6 patients with progressive glioblastoma was performed after resection at recurrence. Median OS was 8.6 months and the authors concluded there was an immune response induced in patients but not enough to delay or prevent disease progression.[90] This was in a small group of patients without control and designated as Class III evidence.

Dillman et al prospectively evaluated intralesional lymphokine-activated killer cells (LAKs) in 40 patients after surgery. Median OS was 9 months with a 12-month survival of $34 \%$. The authors concluded that median survival rates were higher than other published series for patients undergoing repeat resection. [93] As it was a relatively small study without a control group, this was deemed Class III.

Hau et al evaluated AP12009, a TGFb2 inhibitor with patient derived glioma cells and peripheral blood mononuclear cells. In 19 patients undergoing direct tumor delivery, results showed a median OS of 10.3 months, although this was not a primary end point of the safety study. The authors concluded the treatment was safe and well tolerated.[96] This warrants Class III designation.

Carpentier et al's study evaluated 24 patients treated at either their first, second, or third recurrence with escalating doses of CpG-28. Median OS was 7.2 months and PFS6 4.5\%- and 12-month survival $28 \%$. Authors felt the treatment was well tolerated, and as a phase I trial without randomization and a small patient population, this was designated Class III evidence.[87]

\section{Convection Enhanced Delivery}

Desjardins et al evaluated intratumoral convection enhanced delivery of recombinant polio-rhinovirus chimera in 61 patients as a dose escalation and dose expansion trial. Median OS reached a plateau of $21 \%$ at 24 months which was sustained at 36 months and the authors concluded the treatment was safe and the survival rate was higher than among historical controls and warranted further evaluation.[92] This was deemed Class III as it lacked a control group and was a phase I dose-escalation trial.

\section{Synthesis:}

The prior guidelines did not discuss immunotherapeutic regimens for progressive glioblastoma. In this update, we reviewed the studies on convection enhanced delivery, varying T-Cell and autologous lymphocyte or mononuclear cell studies, intratumoral agent delivery, vaccinations, and immune checkpoint inhibitors. The highest-level data were in a class I study showing no obvious benefit of a 
personalized peptide vaccine and a class III designated study showing a significant survival benefit in the neoadjuvant and adjuvant administration of pembrolizumab, increasing 6.2 months over the adjuvant only treatment group. The remainder of studies were Class III designations and of little benefit in guiding treatment suggestions as they were mostly early, Phase I safety and tolerability trials pending further efficacy study. This precludes the ability to make a recommendation for or against immunotherapy, suggesting the modality still warrants further evaluation. As such it is suggested that when available, and patients meet inclusion criteria, they be enrolled in properly designed studies of immunotherapy.

Question 7: In adults with progressive glioblastoma is the use of immunotherapy in combination with cytotoxic agents superior to standard salvage cytotoxic chemotherapy as measured by progression free survival and overall survival?

Prior Recommendations: In the previously published guidelines on the role of targeted therapies in management of progressive glioblastoma in adults, immunotherapeutic agents in combination with cytotoxic treatments were not reviewed.

\section{Recommendation}

There is insufficient evidence to support a recommendation regarding this question.

\section{Study selection and characteristics of the updated search:}

The initial search strategy included 904 candidate articles. A total of 31 articles qualified for full text review. From these, 2 articles were included in the final review for question 7 and are included in Table 7 below. [112; 113] 
Table 7

The role of immunotherapy combined with cytotoxic therapy.

$\begin{array}{lll}\begin{array}{l}\text { Author } \\ \text { (year): }\end{array} & \text { Description of study: } & \text { Data Conclusions: } \\ \text { Class: } & \end{array}$

Akasaki (2016)
Study Description:

Single Institution, Phase I/II Trial of Safety and Efficacy of TMZ + Immunotherapy with fusions of dendritic cells and glioma cells in progressive and newly diagnosed glioblastoma

Patient Population:

Adult patients with glioblastoma of which 10 were progressive and 22 were newly diagnosed. Review of the 10 patients' pathology indicated Glioblastoma in 7, Anaplastic Astrocytoma for 2, and Anaplastic Oligodendroglioma in 1.

Treatment Regimen:

Group R (progressive, $\mathrm{n}=10$ ) previously underwent Surgical resection followed by TMZ Chemotherapy and Radiation. At recurrence, TMZ was given at $150-200 \mathrm{mg} / \mathrm{m} 2 /$ day for 5 days of each 28 day treatment cycle. FCs suspended in .5cc normal saline were inoculated intradermally 2 weeks after first maintenance dose of $\mathrm{TMZ}$ and repeated at least 3 times in each cycle. After 3rd inoculation, FC-inoculation was repeated every 6-12 months barring progressive disease.
III

Results:

OS: $18 \mathrm{~m}$, stratified for dose of FC inoculation: < $1 \times 10^{\wedge} 612.6 \mathrm{~m}, 1-2 \times 10^{\wedge} 6$ $18.2,>2 \times 10^{\wedge} 616.1 \mathrm{~m}$

Toxicity:

Injection site Reaction Grade 1: 4,

Lymphopenia/Leukopenia G1: 5,

Lymphopenia/leukopenia G2: 2, no adverse events necessitated halting treatment, no correlation to number of inocluated FCs

Authors' Conclusions:

TMZ + FC immunotherapy may have a capability to enhance the TMZ-based standard adjuvant therapy for patients with GBM and may have a synergistic effect in progressive GBM with acquired chemotherapeutic resistance.

Comments and Conclusions:

A single institution, small nonrandomized study warrants Class III designation.

Abbreviations: $\mathrm{BEV}=$ bevacizumab, OS = overall survival, $\mathrm{PFS}=$ progression free survival, $\mathrm{PFS} 6=$ six month progression free survival, $\mathrm{RR}=$ response rate, $\mathrm{PD}=$ progressive disease, $\mathrm{SD}=$ stable disease, $\mathrm{CR}$ $=$ complete response, $\mathrm{PR}=$ partial response, $\mathrm{AE}=$ adverse event, $\mathrm{TMZ}=$ temozolomide, $\mathrm{GBM}=$ glioblastoma, RT = radiation therapy 


\begin{tabular}{|c|c|c|c|}
\hline $\begin{array}{l}\text { Author } \\
\text { (year): }\end{array}$ & Description of study: & $\begin{array}{l}\text { Data } \\
\text { Class: }\end{array}$ & Conclusions: \\
\hline $\begin{array}{l}\text { Hunn et } \\
\text { al } \\
(2015)\end{array}$ & $\begin{array}{l}\text { Study Description: } \\
\text { Prospective phase I trial of TMZ plus monocyte- } \\
\text { derived dendritic cells (DC) pulsed with autologous } \\
\text { tumor cells. } \\
\text { Patient Population: } \\
14 \text { pts with progressive GBM, } 9 \text { of whom } \\
\text { completed the trial. } \\
\text { Treatment Regimen: } \\
\text { Following leukapheresis to harvest PBMC, } \\
\text { craniotomy for tumor resection occurred. Three } \\
\text { weeks later, patients received a priming course of } \\
\text { three rounds of dendritic cell (DC)-based } \\
\text { vaccination intradermally at } 2 \text {-week intervals, } \\
\text { dosing } 4 \times 10^{\wedge} 6 \text { DC. One week after } 3 \text { rd vaccine, } \\
\text { patients began TMZ } 150-200 \text { mg/m^ } 2 \text { orally for } 5 \\
\text { days every } 28-d a y \text { cycle for up to } 6 \text { cycles. Booster } \\
\text { vaccine of } 1 \times 10^{\wedge} 6 \text { DC was administered } 2 \text { weeks } \\
\text { after each cycle of TMZ. }\end{array}$ & III & $\begin{array}{l}\text { Results: } \\
\text { Nine of } 14 \text { patients } \\
\text { completed the initial } \\
\text { phase of priming } \\
\text { vaccinations and two } \\
\text { cycles of TMZ, one had } \\
\text { radionecrosis, one rapidly } \\
\text { progressed, and in } 3 \text { the } \\
\text { yield of DC vaccine was } \\
\text { insufficient to proceed. } 2 \\
\text { had radiological } \\
\text { responses. } 6 \text { mo PFS } \\
22 \% \text {. } \\
\text { Toxicity: } \\
\text { There were no grade } 4 \\
\text { toxicities, premature } \\
\text { withdrawals due to } \\
\text { treatment-related toxicity, } \\
\text { or AE directly attributable } \\
\text { to vaccination. } \\
\text { Authors' Conclusions: } \\
\text { The combined treatment } \\
\text { was safe and well- } \\
\text { tolerated but feasibility in } \\
\text { the progressive setting } \\
\text { was marginal. Evidence } \\
\text { of immune responses in a } \\
\text { few patients broadly } \\
\text { correlated with better } \\
\text { clinical outcome. } \\
\text { Comments and } \\
\text { Conclusions: } \\
\text { A phase } 1 \text { trial without } \\
\text { control in a small cohort } \\
\text { warrants Class III } \\
\text { designation. }\end{array}$ \\
\hline $\begin{array}{l}\text { Abbrevia } \\
\text { month p } \\
=\text { compl } \\
\text { glioblas }\end{array}$ & $\begin{array}{l}\text { ns: } \mathrm{BEV}=\text { bevacizumab, } \mathrm{OS}=\text { overall survival, } \mathrm{PFS}= \\
\text { ression free survival, } \mathrm{RR}=\text { response rate, } \mathrm{PD}=\text { progr } \\
\text { response, } \mathrm{PR}=\text { partial response, } \mathrm{AE}=\text { adverse event, } \\
\text { la, } \mathrm{RT}=\text { radiation therapy }\end{array}$ & $\begin{array}{l}\text { res } \\
\text { ed }\end{array}$ & $\begin{array}{l}\text { free survival, } \mathrm{PFS6}=\text { six } \\
\text { se, } \mathrm{SD}=\text { stable disease, } \mathrm{CR} \\
\text { ozolomide, GBM = }\end{array}$ \\
\hline
\end{tabular}

In a Phase I trial of temozolomide with monocyte derived dendritic cells pulsed with autologous tumor cells in 14 patients, only 9 of which were included in study results, PFS6 was $22 \%$. Hunn et al concluded this strategy was safe and well tolerated, but the feasibility was marginal and of limited benefit.[112] Akasaki et al performed a Phase I/II trial evaluating TMZ with dendritic cell pulsed with glioma cells in 
both newly diagnosed and progressive glioblastoma. In the seven progressive glioblastoma cases, results showed a mOS of 18 months, with $1 \times 10^{6}$ DC dose yielding 12.6 month mOS, the $1-2 \times 10^{6}$ dose an 18.2 month survival, and the $>2 \times 10^{6}$ dose a 16.1 month survival. Ultimately, authors concluded this immunotherapy may work synergistically with $T M Z$ in progressive glioblastoma patients with acquired TMZ resistance.[113] As these were both small studies with nonrandomized cohorts lacking control groups, these were both designated Class III.

\section{Synthesis:}

As an effect of a small number of studies with Class III data and limited patient populations and efficacy results, we cannot make a recommendation at this time. It would be difficult to evaluate the effect without further data and larger studies with randomized designs with control groups, otherwise one cannot delineate whether effects are synergistic or related to either the cytotoxic or immunotherapy component of the treatment regimen. Thus, there is insufficient evidence on which to base a recommendation regarding this question. Again, it is suggested that when available, and patients meet inclusion criteria, they be enrolled in properly designed studies of immunotherapy in combination with cytotoxic agents.

Question 8: In adults with progressive glioblastoma is the use of immunotherapy in combination with Bevacizumab superior to standard salvage cytotoxic chemotherapy as measured by progression free survival and overall survival?

Prior Recommendations: In the previously published guidelines on the role of targeted therapies in the management of progressive glioblastoma in adults, immunotherapeutic agents combined with bevacizumab were not reviewed.

\section{Recommendation}

There is insufficient evidence to support a recommendation regarding this question.

\section{Study selection and characteristics of the updated search:}

The initial search strategy included 904 candidate articles. A total of 31 articles qualified for full text review. From these, 1 article met inclusion criteria for inclusion in the final review for question 8 and is included in Table 8 below.[114] 
Table 8

The role of immunotherapy combined with bevacizumab.

\begin{tabular}{|c|c|c|c|}
\hline $\begin{array}{l}\text { Author } \\
\text { (year): }\end{array}$ & Description of study: & $\begin{array}{l}\text { Data } \\
\text { Class: }\end{array}$ & Conclusions: \\
\hline \multirow{10}{*}{$\begin{array}{l}\text { Bota } \\
(2018)\end{array}$} & Study Description: & III & Results: \\
\hline & \multirow{3}{*}{\multicolumn{2}{|c|}{$\begin{array}{l}\text { Double Blinded, randomized, Phase II } \\
\text { trial comparing survival in patients with } \\
\text { progressive glioblastoma receiving } \\
\text { ER1671 and Bevacizumab vs } \\
\text { bevacizumab and placebo. }\end{array}$}} & $\begin{array}{l}\text { PFS: } 7.3 \mathrm{~m} \text { in treatment group, } 5.4 \mathrm{~m} \text { in } \\
\text { placebo }\end{array}$ \\
\hline & & & Toxicity: \\
\hline & & & \multirow{2}{*}{$\begin{array}{l}\text { no Grade } 4-5 \text { adverse reaction, } 9 \\
\text { reported headaches (Grade III) }\end{array}$} \\
\hline & Patient Population: & & \\
\hline & \multirow{2}{*}{$\begin{array}{l}9 \text { patients with progressive GBM, older } \\
\text { than } 18 \text {, enrolled, } 5 \text { in the active } \\
\text { treatment group } 4 \text { in placebo. }\end{array}$} & & Authors' Conclusions: \\
\hline & & & \multirow{2}{*}{$\begin{array}{l}\text { In summary, preliminary analysis of } \\
\text { interim results from our study } \\
\text { indicates that the addition of } \\
\text { ERC } 1671 / \text { GMCSF/cyclophosphamide } \\
\text { to bevacizumab resulted in a } \\
\text { clinically meaningful survival benefit } \\
\text { with minimal additional toxicity. The } \\
\text { study is ongoing with the anticipated } \\
\text { addition of two other sites. }\end{array}$} \\
\hline & \multirow{3}{*}{$\begin{array}{l}\text { Treatment Regimen: ERC1671 regimen } \\
\text { consists of ERC-D (inactivated/irradiated } \\
\text { whole tumor cells and lysates form } \\
\text { allogeneic and autologous GBM patients } \\
\text { in combination with immune system } \\
\text { priming agents) and cyclophosphamide } \\
\text { and GM-CSF. Dosing is with immune } \\
\text { priming from Day } 2-5 \text { with } \\
\text { Bevacizumab on Days } 1 \text { and } 15, \text { with } \\
\text { vaccinations given Days } 6,9,12,15,18 \\
\text { and repeated every } 28 \text { days until disease } \\
\text { progression or intolerance. }\end{array}$} & & \\
\hline & & & Comments and Conclusions: \\
\hline & & & $\begin{array}{l}\text { While this is a double-blinded } \\
\text { randomized trial, the limited sample } \\
\text { size and exclusion criteria limit the } \\
\text { conclusions to Class III data. }\end{array}$ \\
\hline \multicolumn{4}{|c|}{$\begin{array}{l}\text { Abbreviations: } \mathrm{BEV}=\text { bevacizumab, } \mathrm{OS}=\text { overall survival, } \mathrm{PFS}=\text { progression free survival, } \mathrm{PFS} 6=\text { six } \\
\text { month progression free survival, } \mathrm{RR}=\text { response rate, } \mathrm{PD}=\text { progressive disease, } \mathrm{SD}=\text { stable disease, } \mathrm{CR} \\
=\text { complete response, } \mathrm{PR}=\text { partial response, } \mathrm{AE}=\text { adverse event }, \mathrm{TMZ}=\text { temozolomide, } \mathrm{GBM}= \\
\text { glioblastoma, } \mathrm{RT}=\text { radiation therapy, } \mathrm{HTN}=\text { hypertension, } \mathrm{CHF}=\text { congestive heart failure, } \mathrm{VTE}= \\
\text { venous thromboembolism, } \mathrm{PE}=\text { pulmonary embolism, }\end{array}$} \\
\hline
\end{tabular}

Bota et al evaluated ER1671 and BEV against BEV monotherapy (placebo) in 9 patients, 5 in the active treatment group and 4 in placebo.[114] ERC1671 consisted of ERC-D (inactivated or irradiated whole tumor cells and lysates from allogeneic and autologous glioblastoma patients in combination with an immune system primer), cyclophosphamide, and GM-CSF. PFS was 7.3 months in the treatment group and 5.4 months in the placebo group. The authors concluded, based in interim results, that there was a meaningful survival benefit with minimal additional toxicity when adding ERC1671, GM-CSF, and cyclophosphamide treatment to BEV. However, the small size of each cohort limits this interpretation and thus this study yields class III data.

\section{Synthesis:}

As there were no combination immunotherapy studies discussed in the prior guidelines, this single study does not provide enough high-level evidence to make a recommendation. Although designated Class III 
with interim results showing a potentially meaningful benefit over placebo when combining autologous and allogeneic tumor lysates as a vaccination combined with BEV treatment, no recommendations for this question are warranted until larger, randomized studies provide further results. It is suggested that when available, and patients meet inclusion criteria, they be enrolled in properly designed studies of immunotherapy in combination with bevacizumab or other targeted agents.

\section{Discussion}

Treatment for progressive glioblastoma has not significantly changed since our prior guidelines were released, and there has not been a significant change in median overall or progression free survival. Each of our questions were formulated to assess the contribution made by targeted therapies and immunotherapy in the treatment of patients with progressive glioblastoma.

In regard to question 1, bevacizumab monotherapy was determined to be effective when compared to standard salvage cytotoxic chemotherapy based on improvements in imaging response and progression free survival at six months, although it did not create any significant improvement in median overall survival in progressive glioblastoma patients. Therefore, our recommendation remains unchanged from the prior guidelines released in 2014

Question 2 sought to address BEV in combination with cytotoxic therapies as a superior treatment regimen to standard salvage cytotoxic therapy. Based on the new available data since 2014, this was found to have no clear survival benefit. More importantly, coupling that lack of evidence with the plethora of information on elevated toxicity in patients receiving BEV in combination with cytotoxic agents, the recommendation was ultimately made Level III against combination therapy. The most important study for this designation with Wick et al, Class I data, with $63.6 \%$ of patients suffering a grade 3 to 5 toxic event.

We then evaluated BEV with other targeted agents in question 3. Three studies providing data that could answer this question included a phase I dose escalation trial and two small nonrandomized studies. There wasn't evidence of high enough power or quality to develop a recommendation, thus further studies need to be performed to further elucidate the potential of this type of regimen.

Question 4 revolved around targeted therapies in relation to standard salvage cytotoxic treatment in progressive glioblastoma. The highest class data evaluated was Class II, including Brown et al in their evaluation of cediranib with gorafenib with only a trend toward improved survival, and Wick et al discussing CD95 pathway inhibition with reirradiation. The remainder of studies did not provide enough evidence of quality to provide a recommendation for or against targeted therapies alone. As such, no recommendation could be made aside from requesting further studies be performed.

When combining targeted with cytotoxic therapy, we also were unable to provide a recommendation. The highest class evidence was Class I, where Batchelor et al studied cediranib and did not find PFS 
prolongation in monotherapy or in combination with lomustine.[80] Two class II studies also did not find any survival benefit.[78; 79]

Immunotherapeutics were a new addition to this set of recommendations. Ultimately, all groups studied under the question of immunotherapy as monotherapy, in combination with targeted agents, or in combination with BEV (questions 5-8) did not reveal sufficient data to provide any recommendations. The highest class designations were a class I study where Narita et al's Phase III trial of a personalized peptide vaccine found no benefit, and a class II study by Cloughesy et al where they discovered a benefit in mOS with neoadjuvant administration of pembrolizumab.[91; 99] Immune checkpoint inhibitors remain of potential interest, albeit present data does not allow us to provide a recommendation.

\section{KEY ISSUES FOR FUTURE RESEARCH}

Targeted and immunotherapies have generated a significant amount of interest and early research into the treatment of recurrent glioblastoma. Unfortunately, there remains insufficient evidence for the recommended use of many of these agents. However, there were some intriguing findings from this review, specifically the potential benefit of treatment with immune checkpoint inhibition prior to and after surgical resection for progressive glioblastoma. This should generate further studies surrounding immunotherapeutics either as monotherapy, in conjunction with resection, or as combination therapies. Additional well designed, larger, randomized controlled clinical trials may provide additional information on this topic.

\section{Conclusion}

This set of recommendations does not substantially affect the current targeted and immunotherapy regimens being offered to patients with progressive glioblastoma. Ideally, clinical trials should include more patients to better evaluate the safety and survival benefits provided. We did make a Level III recommendation against bevacizumab in combination with cytotoxic agents due to the elevated toxicity and lack of benefit in survival, as well as a Level III supporting the use of bevacizumab monotherapy. However, this is not a significant deviation from the previously published guideline on this topic.

To restate, this should not ultimately change the treatment strategies offered by neuro-oncologic specialists in terms of standard treatment regimens. However, there were some intriguing findings, specifically the potential benefit of treatment with immune checkpoint inhibition prior to and after surgical resection for progressive glioblastoma. This should generate further interesting studies surrounding immunotherapeutics either as monotherapy, in conjunction with resection, or as combination therapies.

Ultimately, several limitations exist within our analysis of the literature as well as within the general study designs that prevent our ability to make high-level recommendations. Our search was limited to completed trials with accessible, published data. Our exclusion criteria were strict, resulting in some trials with potentially positive findings and data being excluded due to survival data mixing in pediatric 
patients and/or WHO Grade III astrocytomas or gliosarcoma. However, this allowed us to restrict our analysis to pay very strict attention to and make recommendations for treatment of adult patients with progressive glioblastomas. On the other hand, we were limited in making strong recommendations as many of the trials were statistically underpowered, lacked control groups, sometimes lacked standardization, or have not yet proceeded beyond initial Phase I and Phase II evaluations. In the future, it may be possible that recommendations on these topics will be strengthened due to creation of larger, randomized, multi-center trials addressing the topics of the smaller studies used as evidence in this document.

\section{Abbreviations}

BEV: Bevacizumab

GBM: glioblastoma

PFS: Progression Free Survival

PFS6 : 6 month Progression Free Survival

mOS: Median Overall Survival

OS: Overall Survival

PRISMA: Preferred Reporting Items for Systematic Reviews and Meta-Analyses

\section{Declarations}

\section{Conflict of Interest (COI)}

All Guideline Task Force members were required to disclose all potential COls prior to beginning work on the guideline, using the COI disclosure form of the AANS/CNS Joint Guidelines Review Committee. The CNS Guidelines Committee and Guideline Task Force Chair reviewed the disclosures and either approved or disapproved the nomination and participation on the task force. The CNS Guidelines Committee and Guideline Task Force Chair may approve nominations of task force members with possible conflicts and restrict the writing, reviewing, and/or voting privileges of that person to topics that are unrelated to the possible COls. The authors have no personal, financial, or institutional interest in any of the drugs, materials, or devices described in this series of articles.

\section{Disclosures}

These guidelines were funded exclusively by the Congress of Neurological Surgery and the Joint Section on Tumors of the Congress of Neurological Surgeons and the American Association of Neurological 
Surgeons, which received no funding from any outside commercial sources to support the development of this document.

\section{Disclaimer of Liability}

This clinical systematic review and evidence-based guideline was developed by a multidisciplinary physician volunteer task force and serves as an educational tool designed to provide an accurate review of the subject matter covered. These guidelines are disseminated with the understanding that the recommendations by the authors and consultants who have collaborated in their development are not meant to replace the individualized care and treatment advice from a patient's physician(s). If medical advice or assistance is required, the services of a competent physician should be sought. The proposals contained in these guidelines may not be suitable for use in all circumstances. The choice to implement any particular recommendation contained in these guidelines must be made by a managing physician in light of the situation in each particular patient and on the basis of existing resources.

\section{Acknowledgements}

The guidelines task force would like to acknowledge the Congress of Neurological Surgeons Guidelines Committee for their contributions throughout the development of the guideline, and the American Association of Neurological Surgeons/Congress of Neurological Surgeons Joint Guidelines Review Committee for their review, comments, and suggestions throughout peer review, as well as the contributions of Trish Rehring, MPH, CHES, Senior Manager of Clinical Practice Guidelines for the CNS, and Mary Bodach, MLIS, from the Congress of Neurological Surgeons Guidelines Office for organizational assistance and reference librarian services, respectively as well as Jeremy Kupsco, PhD, Informationist, Emory University, for their valuable input as Medical Research Librarians. Throughout the review process, the reviewers and authors were blinded from one another. At this time the guidelines task force would like to acknowledge the following individual peer reviewers for their contributions: John O'Toole, MD, Brian Howard, MD, Jamie Van Gompel, MD, Howard Silberstein, MD, Navid Redjal, MD and Shawn HerveyJumper, MD.

\section{References}

$1 \quad$ Ryken TC, Aygun N, Morris J et al (2014) The role of imaging in the management of progressive glioblastoma : a systematic review and evidence-based clinical practice guideline. J Neurooncol 118:435460

2 Stupp R, Mason WP, van den Bent MJ et al (2005) Radiotherapy plus concomitant and adjuvant temozolomide for glioblastoma. N Engl J Med 352:987-996

3 Yong RL, Wu T, Mihatov $\mathrm{N}$ et al (2014) Residual tumor volume and patient survival following reoperation for recurrent glioblastoma. J Neurosurg 121:802-809 

analysis for high-grade recurrent glioma. Neuro Oncol 12:164-172

5 De Bonis P, Fiorentino A, Anile $C$ et al (2013) The impact of repeated surgery and adjuvant therapy on survival for patients with recurrent glioblastoma. Clin Neurol Neurosurg 115:883-886

6 Zhang L, Ajiferuke I, Sampson M (2006) Optimizing search strategies to identify randomized controlled trials in MEDLINE. BMC Med Res Methodol 6:23

$7 \quad$ Wong SS, Wilczynski NL, Haynes RB (2006) Comparison of top-performing search strategies for detecting clinically sound treatment studies and systematic reviews in MEDLINE and EMBASE. J Med Libr Assoc 94:451-455

$8 \quad$ Wilczynski NL, Haynes RB, Hedges T (2007) EMBASE search strategies achieved high sensitivity and specificity for retrieving methodologically sound systematic reviews. J Clin Epidemiol 60:29-33

$9 \quad$ Wilczynski NL, Haynes RB, Hedges T (2004) Developing optimal search strategies for detecting clinically sound prognostic studies in MEDLINE: an analytic survey. BMC Med 2:23

10 Topfer LA, Parada A, Menon D, Noorani H, Perras C, Serra-Prat M (1999) Comparison of literature searches on quality and costs for health technology assessment using the MEDLINE and EMBASE databases. Int J Technol Assess Health Care 15:297-303

11 Montori VM, Wilczynski NL, Morgan D, Haynes RB, Hedges T (2005) Optimal search strategies for retrieving systematic reviews from Medline: analytical survey. BMJ 330:68

12 Kastner M, Wilczynski NL, Walker-Dilks C, McKibbon KA, Haynes B (2006) Age-specific search strategies for Medline. J Med Internet Res 8:e25

13 Haynes RB, McKibbon KA, Wilczynski NL, Walter SD, Werre SR, Hedges T (2005) Optimal search strategies for retrieving scientifically strong studies of treatment from Medline: analytical survey. BMJ 330:1179

14 Cai LB, Li J, Lai MY et al (2013) Bevacizumab rescue therapy extends the survival in patients with recurrent malignant glioma. Chin J Cancer Res 25:206-211

15 Flieger M, Ganswindt U, Schwarz SB et al (2014) Re-irradiation and bevacizumab in recurrent high-grade glioma: an effective treatment option. J Neurooncol 117:337-345

16 Kaloshi G, Brace G, Rroji A et al (2013) Bevacizumab alone at $5 \mathrm{mg} / \mathrm{kg}$ in an every-3-week schedule for patients with recurrent glioblastomas: a single center experience. Tumori 99:601-603

17 Nagane M, Nishikawa R, Narita $Y$ et al (2012) Phase Il study of single-agent bevacizumab in Japanese patients with recurrent malignant glioma. Jpn J Clin Oncol 42:887-895 
18 Piccioni DE, Selfridge J, Mody RR et al (2014) Deferred use of bevacizumab for recurrent glioblastoma is not associated with diminished efficacy. Neuro Oncol 16:815-822

19 Wenger KJ, Wagner M, You SJ et al (2017) Bevacizumab as a last-line treatment for glioblastoma following failure of radiotherapy, temozolomide and lomustine. Oncol Lett 14:1141-1146

20 Balana C, Estival A, Pineda E et al (2017) Prolonged survival after bevacizumab rechallenge in glioblastoma patients with previous response to bevacizumab(dagger). Neurooncol Pract 4:15-23

21 Raizer JJ, Grimm S, Chamberlain MC et al (2010) A phase 2 trial of single-agent bevacizumab given in an every-3-week schedule for patients with recurrent high-grade gliomas. Cancer 116:5297-5305

22 Kreisl TN, Kim L, Moore K et al (2009) Phase II trial of single-agent bevacizumab followed by bevacizumab plus irinotecan at tumor progression in recurrent glioblastoma. J Clin Oncol 27:740-745

23 Friedman HS, Prados MD, Wen PY et al (2009) Bevacizumab alone and in combination with irinotecan in recurrent glioblastoma. J Clin Oncol 27:4733-4740

24 Vredenburgh JJ, Desjardins A, Herndon JE, 2nd et al (2007) Phase II trial of bevacizumab and irinotecan in recurrent malignant glioma. Clin Cancer Res 13:1253-1259

25 Arakawa Y, Mizowaki T, Murata D et al (2013) Retrospective analysis of bevacizumab in combination with ifosfamide, carboplatin, and etoposide in patients with second recurrence of glioblastoma. Neurol Med Chir (Tokyo) 53:779-785

26 Badruddoja MA, Pazzi M, Sanan A et al (2017) Phase II study of bi-weekly temozolomide plus bevacizumab for adult patients with recurrent glioblastoma. Cancer Chemother Pharmacol 80:715-721

27 Brandes AA, Finocchiaro G, Zagonel V et al (2016) AVAREG: a phase II, randomized, noncomparative study of fotemustine or bevacizumab for patients with recurrent glioblastoma. Neuro Oncol 18:1304-1312

28 Brandes AA, Gil-Gil M, Saran F et al (2019) A Randomized Phase II Trial (TAMIGA) Evaluating the Efficacy and Safety of Continuous Bevacizumab Through Multiple Lines of Treatment for Recurrent Glioblastoma. Oncologist 24:521-528

29 Brenner A, Zuniga R, Sun JD et al (2018) Hypoxia-activated evofosfamide for treatment of recurrent bevacizumab-refractory glioblastoma: a phase I surgical study. Neuro Oncol 20:1231-1239

30 Field KM, Simes J, Nowak AK et al (2015) Randomized phase 2 study of carboplatin and bevacizumab in recurrent glioblastoma. Neuro Oncol 17:1504-1513

31 Gil MJ, de Las Penas R, Reynes G et al (2012) Bevacizumab plus irinotecan in recurrent malignant glioma shows high overall survival in a multicenter retrospective pooled series of the Spanish 
Neuro-Oncology Research Group (GEINO). Anticancer Drugs 23:659-665

32 Gilbert MR, Pugh SL, Aldape K et al (2017) NRG oncology RTOG 0625: a randomized phase II trial of bevacizumab with either irinotecan or dose-dense temozolomide in recurrent glioblastoma. $J$ Neurooncol 131:193-199

33 Heiland DH, Masalha W, Franco P, Machein MR, Weyerbrock A (2016) Progression-free and overall survival in patients with recurrent Glioblastoma multiforme treated with last-line bevacizumab versus bevacizumab/lomustine. J Neurooncol 126:567-575

34 Jakobsen JN, Urup T, Grunnet K et al (2018) Toxicity and efficacy of lomustine and bevacizumab in recurrent glioblastoma patients. J Neurooncol 137:439-446

35 Johansen MD, Urup T, Holst CB et al (2018) Outcome of Bevacizumab Therapy in Patients with Recurrent Glioblastoma Treated with Angiotensin System Inhibitors. Cancer Invest 36:512-519

36 Pasqualetti F, Pace A, Gonnelli A et al (2018) Single-agent Bevacizumab in Recurrent Glioblastoma After Second-line Chemotherapy With Fotemustine: The Experience of the Italian Association of Neuro-Oncology. Am J Clin Oncol 41:1272-1275

37 Peters KB, Lipp ES, Miller E et al (2018) Phase I/II trial of vorinostat, bevacizumab, and daily temozolomide for recurrent malignant gliomas. J Neurooncol 137:349-356

38 Rahman R, Hempfling K, Norden AD et al (2014) Retrospective study of carmustine or lomustine with bevacizumab in recurrent glioblastoma patients who have failed prior bevacizumab. Neuro Oncol 16:1523-1529

39 Sepulveda JM, Belda-Iniesta C, Gil-Gil M et al (2015) A phase II study of feasibility and toxicity of bevacizumab in combination with temozolomide in patients with recurrent glioblastoma. Clin Transl Oncol 17:743-750

40 Taal W, Oosterkamp HM, Walenkamp AM et al (2014) Single-agent bevacizumab or lomustine versus a combination of bevacizumab plus lomustine in patients with recurrent glioblastoma (BELOB trial): a randomised controlled phase 2 trial. Lancet Oncol 15:943-953

41 Vaccaro V, Fabi A, Vidiri A et al (2014) Activity and safety of bevacizumab plus fotemustine for recurrent malignant gliomas. Biomed Res Int 2014:351252

42 Weathers SP, Han X, Liu DD et al (2016) A randomized phase II trial of standard dose bevacizumab versus low dose bevacizumab plus lomustine (CCNU) in adults with recurrent glioblastoma. J Neurooncol 129:487-494

43 Wick W, Gorlia T, Bendszus M et al (2017) Lomustine and Bevacizumab in Progressive Glioblastoma. N Engl J Med 377:1954-1963 
44 Mrugala MM, Crew LK, Fink JR, Spence AM (2012) Carboplatin and bevacizumab for recurrent malignant glioma. Oncol Lett 4:1082-1086

45 Odia Y, Iwamoto FM, Moustakas A et al (2016) A phase II trial of enzastaurin (LY317615) in combination with bevacizumab in adults with recurrent malignant gliomas. J Neurooncol 127:127-135

46 Lassen U, Chinot OL, McBain C et al (2015) Phase 1 dose-escalation study of the antiplacental growth factor monoclonal antibody R05323441 combined with bevacizumab in patients with recurrent glioblastoma. Neuro Oncol 17:1007-1015

47 D'Alessandris QG, Montano N, Cenci T et al (2013) Targeted therapy with bevacizumab and erlotinib tailored to the molecular profile of patients with recurrent glioblastoma. Preliminary experience. Acta Neurochir (Wien) 155:33-40

48 Odia Y, Sul J, Shih JH et al (2016) A Phase II trial of tandutinib (MLN 518) in combination with bevacizumab for patients with recurrent glioblastoma. CNS Oncol 5:59-67

49 Wuthrick EJ, Curran WJ, Jr., Camphausen K et al (2014) A pilot study of hypofractionated stereotactic radiation therapy and sunitinib in previously irradiated patients with recurrent high-grade glioma. Int J Radiat Oncol Biol Phys 90:369-375

50 Wick W, Fricke $\mathrm{H}$, Junge $\mathrm{K}$ et al (2014) A phase II, randomized, study of weekly APG101+reirradiation versus reirradiation in progressive glioblastoma. Clin Cancer Res 20:6304-6313

51 Wen PY, Touat M, Alexander BM et al (2019) Buparlisib in Patients With Recurrent Glioblastoma Harboring Phosphatidylinositol 3-Kinase Pathway Activation: An Open-Label, Multicenter, Multi-Arm, Phase II Trial. J Clin Oncol 37:741-750

52 Pitz MW, Eisenhauer EA, MacNeil MV et al (2015) Phase II study of PX-866 in recurrent glioblastoma. Neuro Oncol 17:1270-1274

53 Phuphanich S, Raizer J, Chamberlain M et al (2017) Phase II study of MEDI-575, an anti-plateletderived growth factor-alpha antibody, in patients with recurrent glioblastoma. J Neurooncol 131:185-191

54 Pan E, Yu D, Yue B et al (2012) A prospective phase II single-institution trial of sunitinib for recurrent malignant glioma. J Neurooncol 110:111-118

55 Muhic A, Poulsen HS, Sorensen M, Grunnet K, Lassen U (2013) Phase Il open-label study of nintedanib in patients with recurrent glioblastoma multiforme. J Neurooncol 111:205-212

56 Lombardi G, De Salvo GL, Brandes AA et al (2019) Regorafenib compared with lomustine in patients with relapsed glioblastoma (REGOMA): a multicentre, open-label, randomised, controlled, phase 2 trial. Lancet Oncol 20:110-119 

mafodotin + temozolomide in patients with EGFR-amplified, recurrent glioblastoma: results from an international phase I multicenter trial. Neuro Oncol 21:106-114

58 Lassman AB, Pugh SL, Gilbert MR et al (2015) Phase 2 trial of dasatinib in target-selected patients with recurrent glioblastoma (RTOG 0627). Neuro Oncol 17:992-998

59 Krolicki L, Bruchertseifer F, Kunikowska J et al (2019) Safety and efficacy of targeted alpha therapy with (213)Bi-DOTA-substance P in recurrent glioblastoma. Eur J Nucl Med Mol Imaging 46:614622

60 Kalpathy-Cramer J, Chandra V, Da X et al (2017) Phase II study of tivozanib, an oral VEGFR inhibitor, in patients with recurrent glioblastoma. J Neurooncol 131:603-610

61 Jia PF, Gu WT, Zhang WF, Li F (2015) Treatment of recurrent malignant gliomas with 13-cisretinoic acid naphthalene triazole. Neurol Sci 36:717-721

62 Hassler MR, Vedadinejad M, Flechl B et al (2014) Response to imatinib as a function of target kinase expression in recurrent glioblastoma. Springerplus 3:111

63 Gerstner ER, Ye X, Duda DG et al (2015) A phase I study of cediranib in combination with cilengitide in patients with recurrent glioblastoma. Neuro Oncol 17:1386-1392

64 Gan HK, Reardon DA, Lassman AB et al (2018) Safety, pharmacokinetics, and antitumor response of depatuxizumab mafodotin as monotherapy or in combination with temozolomide in patients with glioblastoma. Neuro Oncol 20:838-847

65 Gallego O, Cuatrecasas M, Benavides M et al (2014) Efficacy of erlotinib in patients with relapsed gliobastoma multiforme who expressed EGFRVIII and PTEN determined by immunohistochemistry. $\mathrm{J}$ Neurooncol 116:413-419

66 Butowski N, Colman H, De Groot JF et al (2016) Orally administered colony stimulating factor 1 receptor inhibitor PLX3397 in recurrent glioblastoma: an Ivy Foundation Early Phase Clinical Trials Consortium phase II study. Neuro Oncol 18:557-564

67 Brown N, McBain C, Nash S et al (2016) Multi-Center Randomized Phase Il Study Comparing Cediranib plus Gefitinib with Cediranib plus Placebo in Subjects with Recurrent/Progressive Glioblastoma. PLoS One 11:e0156369

68 Batchelor TT, Gerstner ER, Ye X et al (2017) Feasibility, phase I, and phase II studies of tandutinib, an oral platelet-derived growth factor receptor-beta tyrosine kinase inhibitor, in patients with recurrent glioblastoma. Neuro Oncol 19:567-575 

trial of AXL1717 for treatment of relapsed malignant astrocytomas: analysis of dose and response. Oncotarget 8:81501-81510

70 van den Bent M, Gan HK, Lassman AB et al (2017) Efficacy of depatuxizumab mafodotin (ABT414) monotherapy in patients with EGFR-amplified, recurrent glioblastoma: results from a multi-center, international study. Cancer Chemother Pharmacol 80:1209-1217

71 Gilbert MR, Kuhn J, Lamborn KR et al (2012) Cilengitide in patients with recurrent glioblastoma: the results of NABTC 03-02, a phase II trial with measures of treatment delivery. J Neurooncol 106:147153

72 Schiff D, Jaeckle KA, Anderson SK et al (2018) Phase 1/2 trial of temsirolimus and sorafenib in the treatment of patients with recurrent glioblastoma: North Central Cancer Treatment Group Study/Alliance N0572. Cancer 124:1455-1463

73 Jaeckle KA, Hess KR, Yung WK et al (2003) Phase Il evaluation of temozolomide and 13-cisretinoic acid for the treatment of recurrent and progressive malignant glioma: a North American Brain Tumor Consortium study. J Clin Oncol 21:2305-2311

$74 \quad$ Wang L, Liang L, Yang $T$ et al (2017) A pilot clinical study of apatinib plus irinotecan in patients with recurrent high-grade glioma: Clinical Trial/Experimental Study. Medicine (Baltimore) 96:e9053

75 Odia Y, Kreisl TN, Aregawi D, Innis EK, Fine HA (2015) A phase II trial of tamoxifen and bortezomib in patients with recurrent malignant gliomas. J Neurooncol 125:191-195

76 Grisanti S, Ferrari VD, Buglione M et al (2019) Second line treatment of recurrent glioblastoma with sunitinib: results of a phase II study and systematic review of literature. J Neurosurg Sci 63:458-467

77 Duerinck J, Du Four S, Bouttens F et al (2018) Randomized phase II trial comparing axitinib with the combination of axitinib and lomustine in patients with recurrent glioblastoma. J Neurooncol 136:115125

78 Brandes AA, Carpentier AF, Kesari S et al (2016) A Phase II randomized study of galunisertib monotherapy or galunisertib plus lomustine compared with lomustine monotherapy in patients with recurrent glioblastoma. Neuro Oncol 18:1146-1156

79 Blumenthal DT, Rankin C, Stelzer KJ et al (2015) A Phase III study of radiation therapy (RT) and $\mathrm{O}(6)$-benzylguanine + BCNU versus RT and BCNU alone and methylation status in newly diagnosed glioblastoma and gliosarcoma: Southwest Oncology Group (SWOG) study S0001. Int J Clin Oncol 20:650-658

80 Batchelor TT, Mulholland P, Neyns B et al (2013) Phase III randomized trial comparing the efficacy of cediranib as monotherapy, and in combination with lomustine, versus lomustine alone in 
patients with recurrent glioblastoma. J Clin Oncol 31:3212-3218

81 A DIC, Carrabba G, Lanfranchi G, Menghetti C, Rampini P, Caroli M (2013) Continuous tamoxifen and dose-dense temozolomide in recurrent glioblastoma. Anticancer Res 33:3383-3389

82 Couldwell WT, Hinton DR, Surnock AA et al (1996) Treatment of recurrent malignant gliomas with chronic oral high-dose tamoxifen. Clin Cancer Res 2:619-622

83 Graham CD, Kaza N, Klocke BJ et al (2016) Tamoxifen Induces Cytotoxic Autophagy in Glioblastoma. J Neuropathol Exp Neurol 75:946-954

84 Robins $\mathrm{HI}$, Won M, Seiferheld WF et al (2006) Phase 2 trial of radiation plus high-dose tamoxifen for glioblastoma multiforme: RTOG protocol BR-0021. Neuro Oncol 8:47-52

85 Ahmed N, Brawley V, Hegde M et al (2017) HER2-Specific Chimeric Antigen Receptor-Modified Virus-Specific T Cells for Progressive Glioblastoma: A Phase 1 Dose-Escalation Trial. JAMA Oncol 3:10941101

86 Bloch O, Parsa AT (2014) Heat shock protein peptide complex-96 (HSPPC-96) vaccination for recurrent glioblastoma: a phase II, single arm trial. Neuro Oncol 16:758-759

87 Carpentier A, Laigle-Donadey F, Zohar S et al (2006) Phase 1 trial of a CpG oligodeoxynucleotide for patients with recurrent glioblastoma. Neuro Oncol 8:60-66

88 Chamberlain MC, Kim BT (2017) Nivolumab for patients with recurrent glioblastoma progressing on bevacizumab: a retrospective case series. J Neurooncol 133:561-569

89 Chang CN, Huang YC, Yang DM et al (2011) A phase I/II clinical trial investigating the adverse and therapeutic effects of a postoperative autologous dendritic cell tumor vaccine in patients with malignant glioma. J Clin Neurosci 18:1048-1054

90 Clavreul A, Piard N, Tanguy JY et al (2010) Autologous tumor cell vaccination plus infusion of GM-CSF by a programmable pump in the treatment of recurrent malignant gliomas. $J$ Clin Neurosci $17: 842-848$

91 Cloughesy TF, Mochizuki AY, Orpilla JR et al (2019) Neoadjuvant anti-PD-1 immunotherapy promotes a survival benefit with intratumoral and systemic immune responses in recurrent glioblastoma. Nat Med 25:477-486

92 Desjardins A, Gromeier M, Herndon JE, 2nd et al (2018) Recurrent Glioblastoma Treated with Recombinant Poliovirus. N Engl J Med 379:150-161

93 Dillman RO, Duma CM, Schiltz PM et al (2004) Intracavitary placement of autologous lymphokine-activated killer (LAK) cells after resection of recurrent glioblastoma. J Immunother 27:398- 
94 Fakhrai H, Mantil JC, Liu L et al (2006) Phase I clinical trial of a TGF-beta antisense-modified tumor cell vaccine in patients with advanced glioma. Cancer Gene Ther 13:1052-1060

95 Fenstermaker RA, Ciesielski MJ, Qiu J et al (2016) Clinical study of a survivin long peptide vaccine (SurVaxM) in patients with recurrent malignant glioma. Cancer Immunol Immunother 65:13391352

96 Hau P, Jachimczak P, Schlingensiepen R et al (2007) Inhibition of TGF-beta2 with AP 12009 in recurrent malignant gliomas: from preclinical to phase I/II studies. Oligonucleotides 17:201-212

97 Lukas RV, Rodon J, Becker K et al (2018) Clinical activity and safety of atezolizumab in patients with recurrent glioblastoma. J Neurooncol 140:317-328

98 Mantica M, Pritchard A, Lieberman F, Drappatz J (2018) Retrospective study of nivolumab for patients with recurrent high grade gliomas. J Neurooncol 139:625-631

99 Narita Y, Arakawa Y, Yamasaki F et al (2019) A randomized, double-blind, phase III trial of personalized peptide vaccination for recurrent glioblastoma. Neuro Oncol 21:348-359

100 Plautz GE, Barnett GH, Miller DW et al (1998) Systemic T cell adoptive immunotherapy of malignant gliomas. J Neurosurg 89:42-51

101 Reiss SN, Yerram P, Modelevsky L, Grommes C (2017) Retrospective review of safety and efficacy of programmed cell death-1 inhibitors in refractory high grade gliomas. $\mathrm{J}$ Immunother Cancer $5: 99$

102 Sakai K, Shimodaira S, Maejima S et al (2015) Dendritic cell-based immunotherapy targeting Wilms' tumor 1 in patients with recurrent malignant glioma. J Neurosurg 123:989-997

103 Schalper KA, Rodriguez-Ruiz ME, Diez-Valle R et al (2019) Neoadjuvant nivolumab modifies the tumor immune microenvironment in resectable glioblastoma. Nat Med 25:470-476

104 Schijns VE, Pretto C, Devillers L et al (2015) First clinical results of a personalized immunotherapeutic vaccine against recurrent, incompletely resected, treatment-resistant glioblastoma multiforme (GBM) tumors, based on combined allo- and auto-immune tumor reactivity. Vaccine 33:26902696

105 Schuessler A, Smith C, Beagley L et al (2014) Autologous T-cell therapy for cytomegalovirus as a consolidative treatment for recurrent glioblastoma. Cancer Res 74:3466-3476

106 Shibao S, Ueda R, Saito K et al (2018) A pilot study of peptide vaccines for VEGF receptor 1 and 2 in patients with recurrent/progressive high grade glioma. Oncotarget 9:21569-21579 
107 Tanaka M, Tsuno NH, Fujii T, Todo T, Saito N, Takahashi K (2013) Human umbilical vein endothelial cell vaccine therapy in patients with recurrent glioblastoma. Cancer Sci 104:200-205

108 Terasaki M, Shibui S, Narita Y et al (2011) Phase I trial of a personalized peptide vaccine for patients positive for human leukocyte antigen-A24 with recurrent or progressive glioblastoma multiforme. J Clin Oncol 29:337-344

109 Tsuboi A, Hashimoto N, Fujiki F et al (2019) A phase I clinical study of a cocktail vaccine of Wilms' tumor 1 (WT1) HLA class I and II peptides for recurrent malignant glioma. Cancer Immunol Immunother 68:331-340

110 Tsuboi K, Saijo K, Ishikawa E et al (2003) Effects of local injection of ex vivo expanded autologous tumor-specific T lymphocytes in cases with recurrent malignant gliomas. Clin Cancer Res 9:3294-3302

111 Yamanaka R, Homma J, Yajima N et al (2005) Clinical evaluation of dendritic cell vaccination for patients with recurrent glioma: results of a clinical phase I/II trial. Clin Cancer Res 11:4160-4167

112 Hunn MK, Bauer E, Wood CE et al (2015) Dendritic cell vaccination combined with temozolomide retreatment: results of a phase I trial in patients with recurrent glioblastoma multiforme. $\mathrm{J}$ Neurooncol 121:319-329

113 Akasaki Y, Kikuchi T, Homma S et al (2016) Phase I/II trial of combination of temozolomide chemotherapy and immunotherapy with fusions of dendritic and glioma cells in patients with glioblastoma. Cancer Immunol Immunother 65:1499-1509

114 Bota DA, Chung J, Dandekar M et al (2018) Phase II study of ERC1671 plus bevacizumab versus bevacizumab plus placebo in recurrent glioblastoma: interim results and correlations with CD4(+) Tlymphocyte counts. CNS Oncol 7:CNS22

\section{Figures}




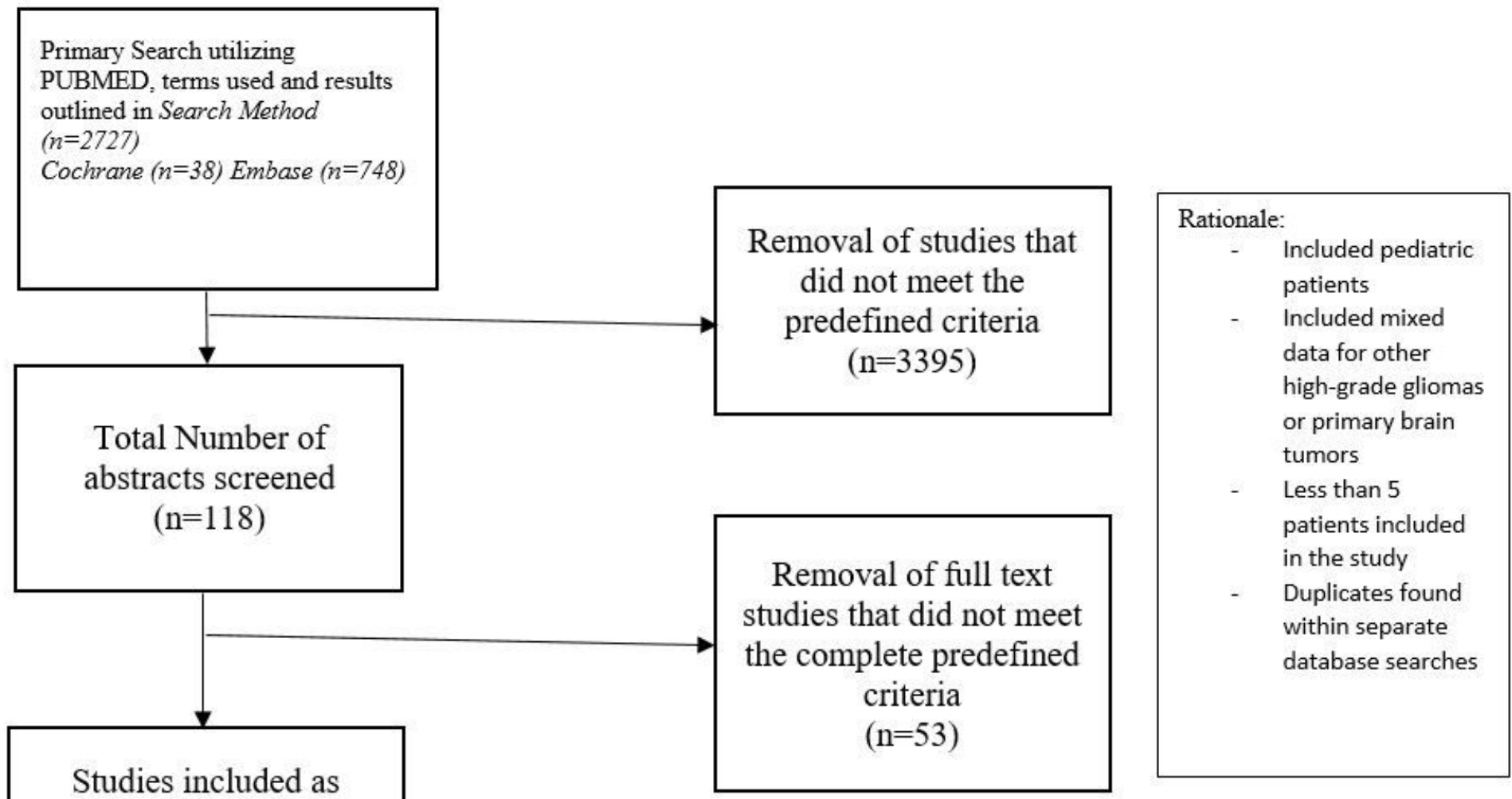

Figure 1

PRISMA Diagram - Depicting the process of searching for, including, and excluding (as well as rationale) studies on targeted therapies for treating progressive glioblastoma 


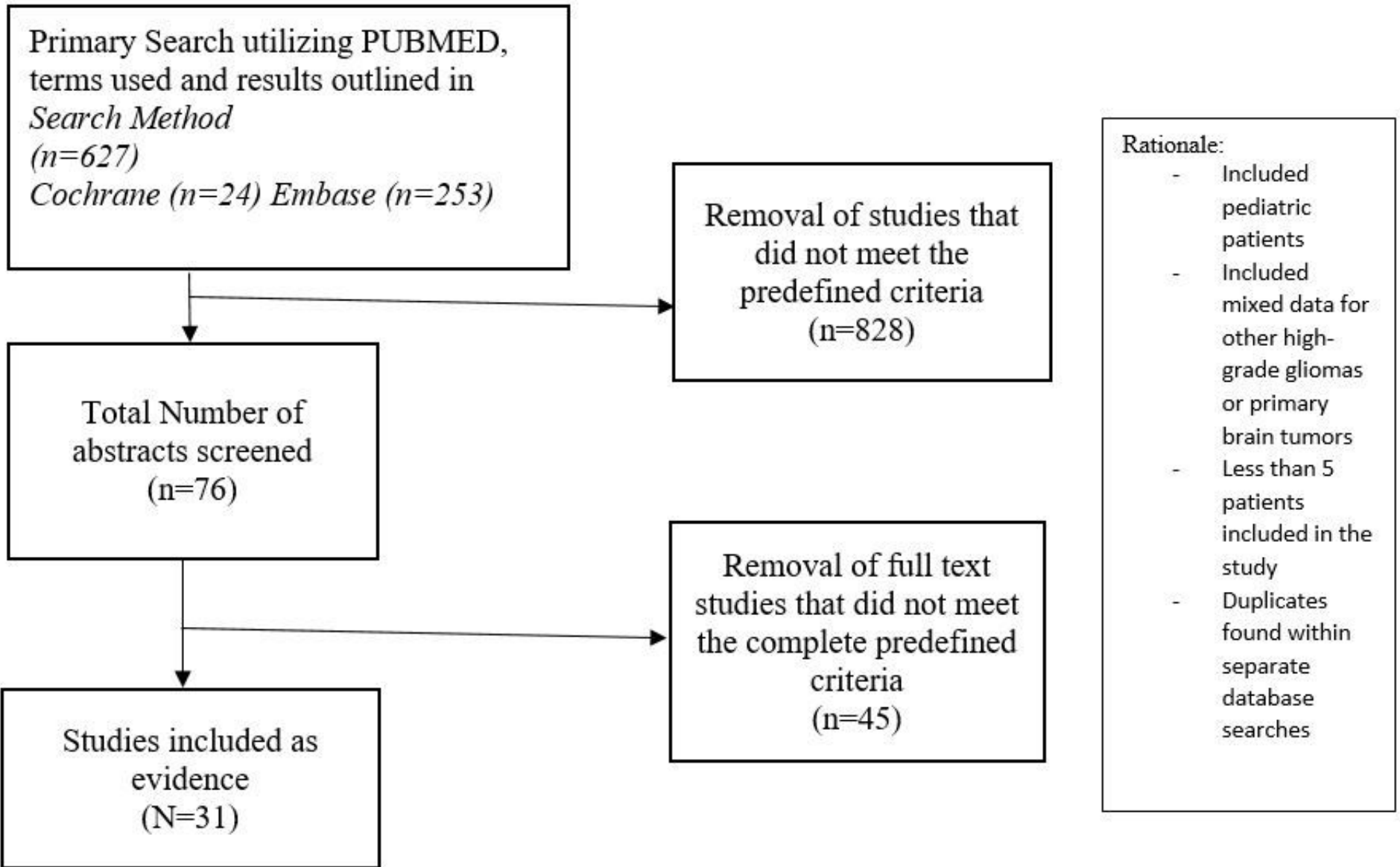

Figure 2

PRISMA Diagram - Depicting the process of searching for, including, and excluding (as well as rationale) studies on immunotherapy for treating progressive glioblastoma

\section{Supplementary Files}

This is a list of supplementary files associated with this preprint. Click to download.

- AuthorstatementsFINAL.docx 